TALES PICCHI ALVES

\title{
A RELEVÂNCIA ECONÔMICA DA GARANTIA DE EMPREGO
}

\author{
DisSERTAÇ̃̃o - MESTRADO
}

Orientador: Prof. Titular Sergio Pinto Martins

FACULDADE DE DIREITO DA USP

SÃO PAULO

2012 
TALES PICCHI ALVES

\title{
A RELEVÂNCIA ECONÔMICA DA GARANTIA DE EMPREGO
}

\author{
Dissertação de Mestrado apresentada à Banca \\ Examinadora da Faculdade de Direito da \\ Universidade de São Paulo, como exigência parcial \\ para a obtenção do título de Mestre em Direito, sob \\ orientação do Prof. Titular Sergio Pinto Martins
}

FACULDADE DE DIREITO DA USP

SÃO PAULO

2012 
BANCA EXAMINADORA

Prof. Titular Sergio Pinto Martins (Orientador) 
"Mais que ser dirigida às vítimas do mercado de trabalho e antes que os destinar a transformar o trabalho visto como mercadoria em trabalho visto como a base de um direito de cidadania industrial, o significado estratégico das políticas sociais passa a ser hoje o de uma arma para a modernização industrial competitiva". (Claus Offe, 1993). 


\section{RESUMO}

O presente trabalho pretende analisar os reflexos econômicos da atuação dos sindicatos e da proibição da dispensa sem justa causa. Para tanto, propõe-se estudar os efeitos da globalização sobre o movimento sindical e sobre o mercado de trabalho nacional. Em seguida, delimita-se o espectro econômico pelo qual será possível analisar que tipo de efeitos a atuação sindical produz sobre o mercado de trabalho e relacioná-los com a proibição da dispensa sem justa causa.

Palavras-chaves: Sindicalismo; transformação de Trabalho; Globalização 


\begin{abstract}
This work intends to analyze the impacts of economic activities of trade unions and the prohibition of dismissal without cause. It is therefore proposed to study the effects of globalization on the labor movement and the national labor market. Then, delimit the economic spectrum that will analyze what effect the union activity has on the labor market and relate it to the prohibition of dismissal without cause
\end{abstract}

Keywords: Syndicalism; Work transformation; Globalization 


\section{SUMÁRIO}

1.1. Movimento sindical - aspectos históricos 10

1.2. Movimento sindical no Brasil

2. MERCADO DE TRABALHO X DESENVOLVIMENTO ECONÔMICO 28

2.1. Globalização e mercado de trabalho .28

2.2. O emprego no setor de serviços 39

2.3. O fenômeno da terciarização. 41

2.3.1. As críticas ao processo de terciarização da economia. 44

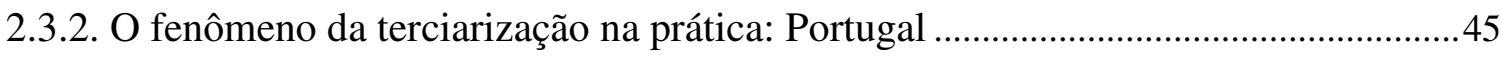

2.3.3. Breve escorso sobre Externalização. 49

2.4. A atuação sindical em tempos de globalização .52

\section{SINDICATO E GARANTIA DE EMPREGO} 58

3.1. A regulação do mercado de trabalho e o papel dos sindicatos 58

3.2. Análise econômica dos sindicatos

\section{AS LEIS DE MARSHALL NA ANÁLISE ECONÔMICA DOS SINDICATOS} .65

4.1. As Leis de Marshall. 65

4.2. A mão-de-obra como produto. 67

4.3. A regulação do mercado de trabalho e o papel dos sindicatos .69

4.4. A proibição da dispensa imotivada para diminuir a elasticidade do mercado de trabalho .70

4.4.1. A internacionalização de regras trabalhistas e a Convenção 158 da OIT .72

4.4.2. A proibição de dispensa imotivada constante na Convenção 158 da OIT. .75

4.4.3 A Convenção 158 e o poder de dispensar empregados .78

4.4.4. O poder de dispensar e a elasticidade da demanda no mercado de trabalho 80 
4.4.5. A Convenção 158 e o poder de dispensar empregados

.82

4.6. A proibição da dispensa imotivada para diminuir a elasticidade do mercado de trabalho

4.7. Dispensa sem justa causa.. 


\section{INTRODUÇÃO}

Desde meados dos anos 1970, os países que alcançaram desenvolvimento econômico no pós-segunda guerra mundial vêm se debatendo em relação a como administrar seus mercados de trabalho e as garantias sociais ligadas a ele.

Após os choques de petróleo da década de 1970, os custos de produção do setor industrial aumentaram muito e as empresas perderam margem de lucro para continuar se expandindo e desenvolvendo negócios. Dessa forma, EUA e Europa iniciaram a década de 1980 experimentando recessões graves e com a economia estagnada.

Nesse contexto, para diminuir custos de produção e fazer sobrar dinheiro para estimular a atividade econômica, começaram a ser implementadas medidas para tornar mais flexíveis as regras protetivas do trabalho e iniciou-se um embate com o movimento sindical que culminou com o enfraquecimento deste.

Esse cenário foi vivenciado nos países centrais, mas países marginais, como o Brasil à época, sofreram seus reflexos mesmo sem ter parques industriais plenamente desenvolvidos, nem legislação trabalhista ou garantias sociais nos mesmos patamares daqueles países.

Com esse panorama internacional, o Brasil passou a ser pressionado a promover alterações em sua legislação trabalhista, assim como estava ocorrendo na Europa. Apesar desse contexto desfavorável, em 1988 foi promulgada a atual Constituição brasileira elevando ao nível constitucional uma série de direitos trabalhistas, entre eles o da proibição da dispensa imotivada, porém dependendo de legislação infraconstitucional para sua aplicação.

A proibição da dispensa imotivada vigora em sistemas trabalhistas como o francês e o português, entre outros países europeus e consiste numa medida de estabilização do mercado de trabalho.

O mercado de trabalho é caracterizado por um desequilíbrio natural entre o excesso de mão-de-obra e a escassez de postos de trabalho. Tal descompasso leva à pobreza e à desagregação social, pois o movimento econômico nesses desequilíbrios é 
que o preço do bem mais abundante torne-se cada vez menor em relação à escassez da demanda. Ou seja, o preço dos salários seja achatado ao mínimo em virtude de haver muitos trabalhadores que necessitam emprego e, de outro lado, haver poucos empregos disponíveis.

Por esse motivo, percebe-se que o mercado de trabalho necessita inescapavelmente de um mecanismo regulatório a fim de se evitar esse quadro em que os trabalhadores são obrigados a vender sua força de trabalho por um preço cada vez menor na competição por postos de trabalho.

A proibição da dispensa imotivada é uma dessas medidas regulatórias que pode ser aplicada nos mercados de trabalho. Da mesma forma, a atuação sindical produz efeitos nesse mesmo sentido.

Por meio das Leis de Marshall é possível entender como esses mecanismos regulatórios agem sobre o mercado de trabalho e tornam-se ferramentas hábeis na preservação da dignidade humana em no ambiente de competição por postos de trabalho que, em ultima ratio, é a competição pela própria vida dos trabalhadores e de suas família. 


\title{
1. SINDICALISMO
}

\subsection{Movimento sindical - aspectos históricos}

A história ensina que o berço dos direitos fundamentais encontra-se, desde o final da Idade Média, na Inglaterra. Conforme lembra Alexandre de Moraes, os principais documentos históricos desses Direitos são os seguintes: a Magna Carta Libertatu, de 1215; a Petition of Rigths, de 1628; o Habeas Corpus Act, de 1679; o Bill of Rights, de 1688; e o Act of Settlement, de 1701. ${ }^{1}$

\begin{abstract}
"Do ponto de vista teórico, sempre defendi - e continuo a defender, fortalecido por novos argumentos - que os direitos do homem, por mais fundamentais que sejam, são direitos históricos, ou seja, nascidos em certas circunstâncias, caracterizadas por lutas em defesa de novas liberdades contra velhos poderes, e nascidos de modo gradual, não todos de uma vez e nem de uma vez por todas".
\end{abstract}

No entendimento de Norberto Bobbio, os direitos humanos se afirmaram, de acordo com a história, em quatro gerações: a primeira, dos Direitos Individuais; a segunda, dos Direitos Coletivos; a terceira, dos Direitos dos Povos ou os Direitos de Solidariedade e os da quarta geração, os Direitos de Manipulação Genética. ${ }^{3}$

As gerações de direitos fundamentais não se contrapõem, mas se completam pelo recíproco envolvimento, como afirma Manoel Gonçalves Ferreira Filho:

"A primeira geração seria a dos direitos de liberdade, a segunda, dos direitos de igualdade, a terceira, assim complementaria o lema da Revolução Francesa: liberdade, igualdade, fraternidade". ${ }^{4}$

A segunda geração ${ }^{5}$ de direitos nasceu da necessidade de proteção contra sérias injustiças sociais por consequência da eclosão da Revolução Industrial no final do

\footnotetext{
${ }^{1}$ MORAES, Alexandre de. Direitos humanos fundamentais. São Paulo: Atlas, 2005. p. 7.

${ }^{2}$ BOBBIO, Norberto. A era dos direitos. 11. ed. Rio de Janeiro: Campus, 1992. p. 5.

${ }^{3}$ Id. Ibid., passim.

${ }^{4}$ FERREIRA FILHO, Manoel Gonçalves. Direitos humanos fundamentais. São Paulo: Saraiva, 2002. p. 7.

${ }^{5}$ Willis Santiago Guerra Filho entende que o uso corrente do termo "geração de direitos humanos", tecnicamente, não é correta. Ao invés de "geração", recomenda-se a utilização do termo "dimensão de
} 
século XIX, que provocara desemprego em massa, aumento demasiado da mão-de-obra desocupada e agravamento da desigualdade social.

Paulo Bonavides leciona que:

\begin{abstract}
“...os direitos sociais fizeram nascer a consciência de que tão importante quanto salvaguardar o indivíduo, conforme ocorreria na concepção clássica dos direitos das liberdades, seria proteger a instituição, uma realidade social mais rica e aberta à participação criativa e a valoração da personalidade que o quadro tradicional da solidão individualista, onde se formara o culto liberal do homem abstrato e insulado, sem a densidade dos valores existenciais, aqueles que unicamente o social proporciona em toda plenitude."
\end{abstract}

O processo de conquista dos direitos sociais foi penoso e sua história está intimamente relacionada à história do movimento sindical.

A história do movimento de união de pessoas identificadas por um mesmo ofício surgiu na Idade Média encontrando sua origem nos sistemas corporativos. Foi na Itália, na França e na Espanha, durante os séculos XII e XIII, que surgiu a corporação, na qual reuniam-se pessoas ligadas por executarem o mesmo tipo de ofício a fim de estabelecer regras às quais todos se sujeitavam. O trabalho dos membros das corporações era executado em âmbito doméstico sendo e para que os artesãos pudessem montar a própria oficina, era necessário que fossem alçados à categoria de mestre.

As corporações de ofício foram associações que surgiram com o objetivo de regulamentar a capacidade produtiva artesanal e foram assinaladas pela seguinte estrutura hierárquica:

- Mestres: donos de oficina com experiência em seu ramo de atuação;

- Oficiais: tinham boa experiência na área e recebiam salário pela função e;

direitos humanos", argumentando-se que: "Não se justifica apenas pelo preciosismo de que as gerações anteriores não desaparecem com o surgimento das mais novas. Mais importante é que os direitos gestados em uma geração, quando aparecem em uma ordem jurídica que já traz direitos da geração sucessiva, assumem uma outra dimensão, pois os direitos de gerações mais recentes tornam-se um pressuposto para entendê-los de forma mais adequada e, conseqüentemente, também para melhor realizá-los. Assim, por exemplo, o direito individual de propriedade, num contexto em que se reconhece a segunda dimensão dos direitos fundamentais, só pode ser exercido observando-se sua função social, e com o aparecimento da terceira dimensão, observando-se igualmente sua função ambiental." GUERRA FILHO, Willis Santiago. Processo constitucional e direitos fundamentais. São Paulo: RCS Ed., 2005. p. 47.

${ }^{6}$ BONAVIDES, Paulo. Curso de direito constitucional. São Paulo: Malheiros Ed., 2006. p. 565. 
- Aprendizes: jovens que estavam na oficina para aprender o trabalho. Terminado o aprendizado, os aprendizes tornavam-se companheiros e desempenhavam suas atividades em locais públicos, remunerados pelos mestres. Essa fase durava em média de 2 a 7 anos, sendo que o aprendiz morava na casa do mestre, comia de sua mesa e, muitas vezes, casava-se com sua filha.

"Talvez as corporações de ofício, encontrem correspondência hoje, guardadas as proporções, menos com o sindicato e mais com os conselhos de fiscalização do exercício profissional, com os quais se parecem". ${ }^{7}$

O que parece ter sido uma característica universal nas corporações, foi, de acordo com Mônica de Souza Martins, a do aprendizado, “...cujo principal objetivo era a transmissão da experiência do artesão-mestre. As corporações européias se diferenciaram em relação às demais por conta de sua autonomia: caminhavam fora da hierarquia, caracterizando-se como associações autônomas que negociavam com o governo o seu reconhecimento, mas rejeitavam a sujeição à autoridade ou ao mando do poder público."8

As corporações também objetivavam regular a capacidade produtiva e regulamentar as técnicas de produção. Conforme ensina Segadas Vianna: ${ }^{9}$

\footnotetext{
"A identidade de profissão, como força de aproximação entre homens obrigava-os, para assegurar direitos e prerrogativas, a se unir, e começaram a apontar, aqui e ali, as corporações de ofício ou 'Associações de Artes e Misteres'. O homem que, até então, trabalhava em benefício exclusivo do senhor da terra, tirando como proveito próprio a alimentação, o vestuário e a habitação, passara a exercer sua atividade, sua profissão em forma organizada, se bem que ainda não gozando da inteira liberdade. É que, senhor da disciplina, não só profissional, mas também pessoal do trabalhador, surgia a figura do 'mestre'."
}

\footnotetext{
${ }^{7}$ NASCIMENTO, Amauri Mascaro. Compêndio de direito sindical. 2. ed. São Paulo: LTr, 2000. p. 38.

${ }^{8}$ MARTINS, Mônica de Souza N. Entre a cruz e o capital: as corporações de ofício no Rio de janeiro após a chegada da família Real (1808-1824). Rio de Janeiro: Garamond Universitária, [2008]. Disponível em: $<$ http://www0.rio.rj.gov.br/arquivo/pdf/obras_premiadas_pdf/entre_cruz_capitall.pdf $>$. Acesso em: 14 nov. 2010.

${ }^{9}$ VIANNA, Segadas. Antecedentes históricos. In: MARANHÃO, Délio; SÜSSEKIND, Arnaldo; TEIXEIRA, Lima; VIANNA, Segadas. Instituições de direito do trabalho. 16. ed. São Paulo: LTr, 1996, v. 1, p. 31 .
} 
Cabanellas definiu as corporações como: "organismos dotados de faculdades delegadas do poder público para o exercício de poderes de polícia e de regulamentação e, como entidade privada, com funções complexas de índole social, política e econômica, com peculiaridades em cada cidade ou país, sem prejuízo dos caracteres comuns". ${ }^{10}$ Desse ponto de vista apresentado por Cabanellas, pode-se apreender como era variado o espectro de influência das corporações na vida das sociedades em que se difundiram, pois o autor aponta um estrapolamento da atuação desses entes, não se resumindo somente à "profissão", mas refletindo-se nas ordens social em geral, política e econômica.

Nesse ponto, cabe estabelecer um paralelo entre essa visão sobre as corporações e o mundo laboral contemporâneo, para ressaltar a importância do ambiente de trabalho nos seus mais variados aspectos, porquanto ligado direta ou indiretamente a toda sociedade e seu desenvolvimento.

Para Russomano, as corporações de ofício tinham dois objetivos: a garantia e ampliação dos direitos e privilégios dos participantes das corporações e o controle do mercado produtor. ${ }^{11}$

Exatamente pelo poderio que as corporações acumularam e o domínio que passaram a exercer, em 1791 passaram a ser consideradas incompatíveis com o ideal de liberdade de trabalho do homem e foram banidas. Abolidas as corporações, a proibição de alianças entre trabalhadores foi seguida por diversos países europeus. Na Inglaterra, as leis que proibiram as associações datam de 1799 e 1800, com a edição do "Combination Acts" que considerava a pressão coletiva para reivindicar melhores salários e condições de trabalho como crime de conspiração contra a Coroa. Na França, após a promulgação do Código Penal de 1809, as coalizões, tanto de operários quanto de patrões foram classificadas como delitos e passaram a ser proibidas. ${ }^{12}$

Com o triunfo da Revolução Francesa, a consagração da liberdade e a igualdade de direitos, aplicados no preâmbulo da Constituição de $1791^{13}$ poderia levar a

\footnotetext{
${ }^{10}$ CABANELLAS, Guilhermo. Compendio de derecho laboral. Buenos Aires; Omeba, 1968. p. 72.

${ }^{11}$ RUSSOMANO, Mozart Victor. Princípios gerais de direito sindical. 2. ed. Rio de Janeiro, Forense, 1998. p. 12.

${ }^{12}$ SÜSSEKIND, Arnaldo. Direito internacional do trabalho. São Paulo: LTr, 1987. p. 82.

13“A Assembléia Nacional, desejando estabelecer a Constituição francesa sobre a base dos princípios que ela acaba de reconhecer e declarar, aboliu irrevogavelmente as instituições que ferem a liberdade e a igualdade dos direitos. Não há mais nobreza, nem pariato, nem distinções hereditárias, nem distinções de ordens, nem regime feudal, nem justiças patrimoniais, nem quaisquer dos títulos, denominações e
} 
entender que seria natural permitir que trabalhadores se unissem em torno da identidade profissional. Entretanto a garantia de liberdade individual era o principal objetivo dessa Carta fruto do levante contra os poderes absolutos, sobretudo estatais, o que justifica a proibição quaisquer tipos de associações e acordos coletivos que pudessem se sobrepor à autonomia da vontade individual.

Em 17 de junho de 1791, a Lei Le Chapelier confirmou o Decreto de Allarde (17 de março de 1791), e as relações de trabalho, antes presididas pelos critérios heterônomos das corporações de ofício, foram substituídas por uma regulamentação essencialmente autônoma, assegurando às pessoas a liberdade de dedicar-se a qualquer ofício, proibindo associações de patrões ou operários e tudo que fosse contrário à liberdade de trabalho e comércio. ${ }^{14}$

Para Amauri Mascaro Nascimento:

"a ideia de liberdade de comércio também pesou na supressão das corporações, acusadas de provocar o encarecimento dos produtos, monopolizar o seu setor econômico, impedir o exercício da profissão fora dos seus quadros e restringir a autonomia das pessoas, motivos que explicam o edito de fevereiro de 1776, na França, inspirado por Turgot, precedido de uma exposição de motivos acusando as corporações de instituições arbitrárias, impeditivas ao indigente de viver do seu trabalho, idéias admitidas pelo Parlamento francês, em nome de defesa da liberdade de comércio e de profissão."15

prerrogativas que deles derivavam, nem qualquer ordem de cavalaria, de corporações ou condecorações para as quais se exigiram provas de nobreza, ou que supunham distinções de nascença, nem qualquer outra superioridade senão aquela de funcionários públicos no exercício de suas funções. Não há mais venalidades nem hereditariedade para qualquer cargo público. Não existe mais, para qualquer parte da Nação, nem para qualquer indivíduo, privilégio algum, nem exceção ao direito comum de todos os franceses. Não há mais corporações profissionais, de artes e ofícios. A lei não reconhece os votos religiosos, nem qualquer outro compromisso que seja contrário aos direitos naturais ou à Constituição". Constituição Francesa de 1791.

${ }^{14}$ Lei Le Chapelier: "1. A destruição de todas espécies de corporações de cidadãos do mesmo estado ou profissão sendo uma das bases fundamentais da constituição francesa, são proibidas de serem restabelecidas de fato, sob quaisquer pretexto e forma que seja. 2. Os cidadãos de um mesmo estado ou profissão, os empresários, os que têm loja aberta, os trabalhadores e companheiros de uma arte qualquer, não poderão, quando se encontrarem reunidos, nomear-se nem presidente, nem secretários, nem síndicos, manter registros, tomar decisões e deliberações, formar regulamentos sobre seus pretendidos interesses comuns. (...) 8. Toda reunião composta de artesãos, trabalhadores, companheiros, jornaleiros, ou provocada por eles contra o livre exercício da indústria e do trabalho facultado a toda sorte de pessoas, e sobre toda espécie de condições conveniadas amigavelmente, ou contra a ação da polícia e execução dos julgamentos pronunciados nesta matéria, serão tidos por agrupamentos sediciosos e, como tais, serão dispersados pelos depositários da força pública, sobre as requisições legais que lhe serão feitas, e punidos de acordo com todo o rigor das leis sobre os autores, instigadores e chefes dos ditos agrupamentos, e sobre todos aqueles que cometeram violência por vias de fato e de atos".

${ }^{15}$ NASCIMENTO, Amauri Mascaro. op. cit., p. 39. 
Em 1824, o "Combination Acts", foi revogado e o movimento sindical passa a ser legal na Inglaterra, provocando uma onda de greves. Em 1825, o sindicalismo foi regulamentado e os direitos das coalizões operárias foram limitados à luta pacífica por melhores salários e condições de trabalho.

Na lição de Segadas Viana, o sindicalismo passou a existir com a Revolução Industrial “...ou talvez pouco antes [já] se esboçasse seu surgimento. Foi no fim do século XVI que começou a se desenvolver o comércio internacional, com a criação de mercados, exigindo a produção de bens em maiores quantidades". ${ }^{16}$

"A invenção da máquina e sua aplicação à indústria iriam provocar a
revolução nos métodos de trabalho e, conseqüentemente, nas relações
entre patrões e trabalhadores; primeiramente a máquina de fiar, o
método de pudlagem (que permitiu preparar o ferro de modo a
transformá-lo em aço), o tear mecânico, a máquina a vapor
multiplicando a força de trabalho, tudo isso iria importar na redução da
mão-de-obra porque, mesmo com o aparecimento das grandes oficinas e
fábricas, para obter um determinado resultado na produção não era
necessário tão grande número de operários. Verificaram-se movimentos
de protesto e até mesmo verdadeiras rebeliões, com a destruição de
máquinas, mas, posteriormente, com o desenvolvimento dos sistemas de
comércio, em especial, com a adoção da máquina a vapor nas
embarcações, estenderam-se os mercados e, conseqüentemente, as
indústrias se desenvolveram admitindo um maior número de
trabalhadores, mas seus salários eram baixos porque, com o antigo
sistema do artesanato, cada peça custava muito mais caro do que a
produção em série."17

Gustavo Filipe Barbosa Garcia afirma que a Revolução Industrial foi a primeira razão econômica que causou o surgimento do Direito do Trabalho, em função de o desenvolvimento da máquina a vapor ter provocado a substituição da força humana ${ }^{18}$. Nessa esteira, a exploração da classe trabalhadora, os riscos e o acontecimento de acidentes, além dos baixos salários, motivaram a formação de grupos, com identidade de interesses, dando origem às primeiras organizações sindicais.

"Nos primórdios da industrialização, este desenvolvimento deu lugar a 'condições sociais absolutamente insatisfatórias'. A absoluta liberdade de iniciativa empresarial resultou em grande acumulação de capital, mas

\footnotetext{
${ }^{16}$ SÜSSEKIND, Arnaldo; MARANHÃO, Délio; VIANNA, Segadas; TEIXEIRA FILHO, João de Lima. op. cit., v. 2, p. 1043.

${ }^{17}$ VIANNA, Segadas. Antecedentes históricos. In: MARANHÃO, Délio; SÜSSEKIND, Arnaldo; TEIXEIRA, Lima; VIANNA, Segadas. op. cit., v. 2, p. 32-33.

${ }^{18}$ GARCIA, Gustavo Filipe Barbosa. Curso de direito do trabalho. São Paulo: Método, 2007. p. 32.
} 
do ponto de vista social, era impensável haver harmonia nas relações de trabalho. Noutro passo, afirmam que as relações de trabalho, somente na teoria, resultam de acordo entre as partes, pois, na prática, decorriam regularmente de uma maior ou menor ditadura empresarial; aí compreendem-se: jornadas excessivas, salário de fome, falta de proteção contra acidentes e doenças profissionais e, sobretudo, desmesurada utilização do trabalho de mulheres e crianças." 19

Os sindicatos passaram a ser reconhecidos e, na Inglaterra foi publicado, em 1871, o Trade Unions Act, tornando lícita a atuação dos sindicatos. Na França, em 1884, a edição da Lei Waldeck-Rousseau, concedeu aos sindicatos o direito de constituirse livremente. Em 1886, os Estados Unidos publicaram o American Federation of Labour $^{20}$,

Sobre este período, Amauri Mascaro Nascimento leciona:

\begin{abstract}
"Da simples tolerância para com o movimento sindical, os Estados passaram a reconhecê-lo, de modo expresso, através de leis ordinárias ou constitucionais, como o Trade Unions Act (1871) da Inglaterra, a Lei Waldeck Rousseau (1884), da França, o Clayton Act (1914) dos Estados Unidos, a Constituição do México (1917), a Constituição de Weimar, da Alemanha (1919) etc. O reconhecimento, significando a atividade do Poder Público não repressiva, mas de acolhimento, em suas leis, da realidade sindical, desenvolveu-se, no entanto, em duas diferentes dimensões, de acordo com a postura estatal, de controle do movimento sindical, em alguns casos, de autonomia aos sindicatos, em outros casos, daí resultando o sindicalismo corporativo ou estatal, de um lado, e o sindicalismo fundado no princípio da liberdade sindical, de outro lado." 21
\end{abstract}

Para Antônio Álvares da Silva, "a concentração de empresas e a mudança das técnicas de produção despertaram a consciência classista que marcaria o mundo moderno. $\mathrm{O}$ trabalhador tinha de arranjar meios para enfrentar o novo e potente inimigo: o capitalismo moderno". 22

\footnotetext{
${ }^{19}$ HUECK, A. NIPPERDEY, H.C. Compendio de derecho del trabajo. Trad. Espanhola de Rodriguez Piñero e De La Villa. Madrid: Ed. Revista de Derecho Privado, 1963. p. 28.

${ }^{20}$ Uma das primeiras federações de sindicatos nos Estados Unidos foi fundada em Columbus, Ohio em 1886 por Samuel Gompers como uma reorganização da sua antecessora, a Federação dos Sindicatos Organizado de Ofícios e do Trabalho. DICIONÁRIO Político. AFL (American Federation of Labor). Disponível em: <http://www.marxists.org/portugues/dicionario/verbetes/a/afl.htm>. Acesso em: 23 mar. 2011.

${ }^{21}$ NASCIMENTO, Amauri Mascaro. Direito sindical. São Paulo: Saraiva, 1989. p. 26.

${ }^{22}$ SILVA, Antônio Álvares da. Direito coletivo do trabalho. Rio de Janeiro: Forense, 1979. p. 19.
} 
$\mathrm{Na}$ Itália, o movimento sindical demorou mais para se desenvolver em relação a outros países da Europa. O Codice Penale Sardo, de 1859, repudiava qualquer reunião de empregados com objetivos de luta por melhores salários e condições de trabalho. Somente a partir de 1901, o governo italiano passou a considerar a existência de sindicatos. Em 1889, pelo Códice Penale Zanardelli, eram permitidos a greve e o lockout, desde que não fossem considerados violentos. Após 1906, com a fundação da Confederação Geral dos Trabalhadores (CGL), houve o crescimento dos sindicatos na Itália e, em 1918, foi criada a Confederação Italiana dos Trabalhadores (CIL).

Com a Lei 563, de 03 de abril de 1926, complementada pelo Decreto de $1^{\circ}$ de julho de $1926^{23}$ e, por fim, a Carta del Lavoro, em 1927, consolidou-se o reconhecimento dos sindicatos na Itália.

As questões trabalhistas passaram a ser objeto de um fórum de dimensão internacional com a criação da Organização Internacional do Trabalho - OIT, em $1919^{24}$. Com o objetivo de promover a justiça social e, fazer respeitar os direitos humanos no âmbito do trabalho, a OIT “...procede da convicção de que a justiça social é essencial para garantir uma paz universal e permanente". ${ }^{25}$

Com o passar de décadas e por meio da atuação de diversos movimentos operários em âmbito nacional e internacionalmente, a importância da legislação trabalhista tanto coletiva, quanto individual, se solidificou e, aos poucos, os ordenamentos jurídicos no mundo ocidental como um todo, passaram a adotá-la.

\footnotetext{
23“"A Lei n ${ }^{\circ} 563$, de 3 de abril de 1926, e seu respectivo Regulamento de Execução $n^{\circ} 1.130$, de $1^{\circ}$ de julho de 1926, instituíram o ordenamento corporativo na Itália. Com base em tal legislação, previa-se o reconhecimento legal de uma única associação para cada categoria de empregadores, trabalhadores, artistas e profissionais em geral. Tais associações, por meio de um decreto, tornavam-se pessoas jurídicas de direito público, submetidas a regulamentação e controle por parte do ordenamento estatal." MAGALHÃES, Daniel de Castro. Contratos coletivos de trabalho no sistema jurídico italiano: derrogabilidade/inderrogabilidade e flexibilização. Revista do Tribunal Superior do Trabalho, Brasília, v. 72, n. 2, p. 100, maio/ago. 2006.

${ }^{24}$ A Organização Internacional do Trabalho foi criada pela Conferência da Paz, assinada em Versalhes, na França, em junho de 1919.

${ }^{25}$ DECLARAÇÃO DA OIT SOBRE OS PRINCÍPIOS E DIREITOS FUNDAMENTAIS NO TRABALHO. Disponível em: <http://www.oit.org.br/sites/default/files/topic/oit/doc/declaracao_oit_547.pdf>. Acesso em: 22 nov. 2010.
} 


\subsection{Movimento sindical no Brasil}

No Brasil, mesmo que rudimentarmente, as corporações de ofício também chegaram a existir, tanto que a Constituição Outorgada de 1824, em seu art. 179, inc. XXV determinou: "Ficam abolidas as corporações de ofícios, seus juízes, escrivães, e mestres."

José Martins Catharino ensina que no século XVIII e grande parte do século XIX, a classe trabalhadora brasileira era composta por escravos e livres: "os trabalhadores brasileiros estavam divididos em duas grandes categorias: escravos, agrários e urbanos; e livres, autônomos ou subordinados, urbanos em sua esmagadora maioria. Até a abolição da escravatura, em 13.05.1888, embora, no meio agrário, o servilismo continuasse a dominar" ${ }^{26}$

O século XIX foi marcado pela fundação de diversas associações de trabalhadores, como a Liga Operária, em 1870 e a União Operária, em 1880. A Liga Operária, fundada no Rio de Janeiro em 1870, tinha como objetivo o aumento dos salários e a diminuição da jornada de trabalho, sendo classificada como uma organização socialista por alguns autores. ${ }^{27}$ Já a União Operária, de acordo com Claudio Batalha, tinha "por fim tratar dos interesses gerais da classe operária e das artes no país" e, para ingressar como membro, era necessário, em primeiro lugar, "ser operário, artista [isto é, artesão] ou ter um trabalho material definido". ${ }^{28}$ Com a Lei Áurea, sancionada em 13 de maio de 1888, pode-se apontar que se solidificou a união entre capital e trabalho no Brasil, em virtude da abolição do trabalho escravo.

Em 1903, o Decreto $n^{\circ} .979$ concedeu autorização aos profissionais da agricultura e das indústrias rurais de qualquer gênero a se organizar em sindicatos, com finalidade de estudo, custeio e defesa de seus interesses. Conforme Alice Monteiro de Barros, "Essa legislação possuía caráter mais econômico do que sindical, pois servia de intermediária de crédito em favor dos associados". ${ }^{29}$

\footnotetext{
${ }^{26}$ CATHARINO, José Martins. Tratado elementar de direito sindical. São Paulo: LTr, 1977. p. 41.

${ }^{27}$ BATALHA, Claudio H. M. Sociedades de trabalhadores no Rio de Janeiro do século XIX: algumas reflexões em torno da classe operária. Cadernos AEL, v. 6, n. 10/11, p. 44, 1999. Disponível em: <http://www.ifch.unicamp.br/ael/website-ael_publicacoes/cad-10/Artigo-2-p41.pdf>. Acesso em: 28 set. 2011 .

${ }^{28}$ Id., loc. cit

${ }^{29}$ BARROS, Alice Monteiro de. Curso de direito do trabalho. 3. ed. São Paulo: LTr, 2007. p. 1192.
} 
No ano de 1907, por meio do Decreto-Lei n. 1.637, foram criados os sindicatos profissionais e as sociedades cooperativas, permitindo aos profissionais de profissões similares a liberdade de se organizarem entre si: "Art. $1^{\circ}$ É facultado aos profissionaes de profissões similares ou connexas, inclusive as profissões liberaes, organizarem entre si syndicatos, tendo por fim o estudo, a defesa e o desenvolvimento dos interesses geraes da profissão e dos interesses profissionaes de seus membros". O art. $8^{\circ}$. desse Decreto prevê a criação de Conselhos Permanentes de Conciliação e Arbitragem destinados a resolver conflitos trabalhistas entre empregador e empregado:

"Art. $8^{\circ}$ Os syndicatos que se constituirem com o espirito de harmonia entre patrões e operarios, como sejam os ligados por conselhos permanentes de conciliação e arbitragem, destinados a dirimir as divergencias e contestações entre o capital e o trabalho, serão considerado como representantes legaes da classe integral dos homens do trabalho e, como taes, poderão ser consultados em todos os assumptos da profissão".

O Decreto $n^{0}$. 19.770, de 1931, outorgou à União a competência para legislar sobre matéria trabalhista regulando a sindicalização das classes patronais e operárias. Na Exposição de Motivos para a edição desse Decreto, encontram-se justificativas nas palavras de Lindolfo Collor, Ministro do Trabalho, Indústria e Comércio: ${ }^{30}$

\footnotetext{
"A Revolução de outubro encontrou o trabalho brasileiro na mais completa e dolorosa anarquia. De um modo geral, não há exagero em dizer-se que na situação atual do Brasil o trabalho é ainda considerado mercadoria, sujeita às flutuações da oferta e da procura. Inútil seria a demonstração de que esta concepção utilitarista e retrógrada não está de acordo, já não apenas com as tendências sociais contemporâneas, senão também com o nível das conquistas e as próprias imposições econômicas, definitivamente reconhecidas e aceitas em quase todos os países do Velho e em não poucos do Novo Mundo. Mas no caso do Brasil o menosprezo dos poderes públicos pelos problemas do trabalho cresce de vulto ainda se considerarmos que o nosso País está, por acordos e convenções internacionais, obrigado ao reconhecimento dessas novas diretrizes da política social."
}

${ }^{30}$ NIEMEYER, W. Movimento sindicalista no Brasil. Rio de Janeiro: [s.n.], 1933. p. 94. 
Para Cássio Mesquita Barros, a Exposição de Motivos acima mencionada, deixava clara a finalidade de incorporar o sindicalismo nas leis da República:

\begin{abstract}
"A Exposição de Motivos, que acompanhou esse Decreto $n^{\circ} 19.770$, de 1931, não ocultava a finalidade de, 'Incorporar o sindicalismo no Estado e nas leis da República, essa deve ser e está sendo, para honra de V. Exa. uma das tarefas mais altas, mais nobres e mais justas da Revolução Brasileira'. Para suavizar os conflitos procurou-se implantar uma política de integração entre empregado e empregador, arbitrada pelo Estado. Para a efetivação desse objetivo, o caminho escolhido foi criar o de categorias econômicas e profissionais. A representação sindical foi delimitada em um plano formal, denominado Plano de Enquadramento Sindical, que previa, de um lado, as categorias econômicas e, de outro, as categorias profissionais correspondentes. $\mathrm{O}$ sindicato, por lei, foi erigido em colaborador do Estado." ${ }^{, 31}$
\end{abstract}

Para Segadas Viana, o sindicalismo no Brasil surgiu como consequência do impulso estatal promovido pela Revolução Liberal de 1930, e não por força dos movimentos de massa ocorridos antes dos fenômenos migratórios, quando não existia um ciclo econômico ajustado (não existiam indústrias e nem comércio). ${ }^{32}$ Para o autor:

\begin{abstract}
"As organizações que então surgiram de sindicato apenas possuíam o rótulo. Entre os trabalhadores do campo não existia uma base intelectual que lhes assegurasse capacidade para se organizar, e, além disso, estavam economicamente subjugados aos senhores da terra, que não hesitavam em mandar liquidar os que tivessem coragem de reclamar qualquer medida em seu benefício, já que direitos não existiam consagrados em textos de lei. E não era muito diferente a situação nos centros populosos, não obstante ter sido fundada no Rio de Janeiro, em 1903, a Federação das Associações de Classe, que mais tarde passou a se denominar Federação Operária Regional...”.33
\end{abstract}

Na visão de Segadas Viana, o Decreto no 19.770 estabelecia "a unidade sindical e, para evitar que os sindicatos desvirtuassem suas finalidades, determinava no art. $1^{\circ}$, alínea $f$, dentre as condições para o reconhecimento: abstenção no seio das

\footnotetext{
${ }^{31}$ BARROS, Cássio Mesquita. A influência italiana no direito do trabalho brasileiro. Mesquita Barros Advogados. Disponível em: $<$ http://www.mesquitabarros.com.br/index.php?option=com_content $\&$ view=article\&id=57:ainfluencia-italiana-no-direito-do-trabalho-brasileiro\&catid=7: artigos\&Itemid=3\&lang=en>. Acesso em: 27 nov. 2010.

${ }^{32}$ SÜSSEKIND, Arnaldo; MARANHÃO, Délio; VIANNA, Segadas; TEIXEIRA FILHO, João de Lima. op. cit., p. 1045.

${ }^{33}$ Id. Ibid., p. 1046.
} 
organizações sindicais de toda e qualquer propaganda de ideologias sectárias, de caráter social e político". 34

Em 1932, foram criadas as Comissões Mistas de Conciliação e Julgamento, com competência para dirimir os conflitos trabalhistas entre empregados e empregadores. Em 1939, com a criação da Justiça do Trabalho, regulamentada pelo Decreto-Lei n. 1.237, de 15 de maio de 1939, essas comissões passaram a se denominar Juntas, funcionando com representantes dos empregados e dos empregadores.

Em 1934, a Constituição contemplou o princípio da pluralidade sindical, deixando a cargo do legislador ordinário a regulamentação de tal princípio, ex vi do art. 120:

\footnotetext{
"art. 120 - os sindicatos e as associações profissionais serão reconhecidos de conformidade com a lei.

Parágrafo único - a lei assegurará a pluralidade sindical e a completa autonomia dos sindicatos."
}

Ao longo da década de 30, diversos diplomas legais afeitos aos direitos trabalhistas foram sancionados. A saber: sobre o trabalho feminino (Decreto n. 21.41, de maio de 1932); sobre jornada de trabalho para comerciários (Decreto n. 21.186, de março de 1932) e para os industriários (Decreto n. 21.354, de maio de 1932); sobre o estabelecimento de férias para bancários (Decreto n. 23.103, de agosto de 1933).

De acordo com Vitto Gianotti:

\begin{abstract}
"Os legisladores da década de 30 conheciam muito bem a experiência anterior do nosso movimento operário. $\mathrm{O}$ objetivo da classe que fez essas leis era acabar de vez com o sindicalismo dos anos 20: um sindicalismo que nas suas duas tendências principais, a anarcosindicalista e a comunista, se contrapunha decididamente ao patronato e apontava para os trabalhadores uma sociedade sem classe, sem explorados e sem exploradores. A emulação entre as duas principais tendências do movimento operário pré-30 precisava acabar. Vargas e os legisladores que o assessoravam viram que a unicidade artificial, não politicamente conquistada, era uma garantia melhor para dominar o novo sindicalismo que se tentava construir". ${ }^{35}$
\end{abstract}

\footnotetext{
${ }^{34}$ SÜSSEKIND, Arnaldo; MARANHÃO, Délio; VIANNA, Segadas; TEIXEIRA FILHO, João de Lima. op. cit., p. 1048.

${ }^{35}$ GIANOTTI, Vitto. O que é estrutura sindical? 2. ed. São Paulo: Brasileirense, 1987. p. 31.
} 
Dessa forma, durante o Estado Novo (1937-1945) de Getúlio Vargas, a atividade sindical foi marcada pela instituição do regime corporativista, que permitia a intervenção do Estado nas relações trabalho e capital. A Constituição de 1937 aponta:

\begin{abstract}
"A associação profissional ou sindical é livre. Somente porém o sindicato regularmente constituído pelo Estado tem o direito de representação dos que participem da categoria de produção para que foi constituído, e de defender-lhes os direitos perante o Estado e outras associações profissionais, estipular contratos coletivos de trabalho obrigatórios para os associados, impor-lhes contribuições e exercer em relação a eles funções delegadas de poder público"
\end{abstract}

Getúlio Vargas inspirou-se no modelo corporativista italiano de Mussolini $^{36}$, inserindo considerações doutrinárias do fascismo ao incorporar o corporativismo no ordenamento jurídico brasileiro:

"Na visão fascista, o direito do trabalho, longe de proteger o trabalhador, nele vê apenas um dos fatores da produção. O trabalho só goza da proteção do Estado como dever social. A doutrina corporativista exalta o trabalho, sem, todavia lhe assegurar o primado. O espírito que animava o fascismo italiano era a colaboração entre as classes, o que impedia proclamar a supremacia de uma sobre a outra. De acordo com a declaração II da Carta del Lavoro, o trabalho é um dever social; a esse título, e somente a esse título, é tutelado pelo Estado. Portanto, em vez de sujeito protegido, o trabalhador é visto como elemento de cooperação no esforço de realização dos superiores interesses da produção nacional. No regime corporativista, a legislação do trabalho não tem por fim proteger o empregado. Não move o Estado corporativo qualquer intuito de 'proteger' a classe trabalhadora. $\mathrm{O}$ ordenamento corporativo admite a realidade de interesses coletivos e opostos entre empresários e trabalhadores, todavia supera tal oposição mediante a colaboração coletiva... ",37

A Carta de 1937 determina explicitamente que "fica proibida a greve e o locaute, considerados recursos anti-sociais, nocivos ao capital e ao trabalho e prejudiciais aos superiores interesses da Nação".

\footnotetext{
36“Na Itália de Mussolini, ressalvadas algumas leis sobre limitação da jornada de trabalho e o Real Decretolei n. 1825, de 13-11-1924, sobre contrato de emprego privado (convertido na Lei n. 562, de 18-3-1926), inexistiam disposições legais sobre contrato individual de trabalho. As normas de proteção ao trabalho constavam dos contratos coletivos. O direito do trabalho era, predominantemente, o direito coletivo do trabalho." ROMITA, Arion Sayão. Os direitos sociais na Constituição e outros estudos. São Paulo: LTr, 1991. p. 350.

${ }^{37}$ ROMITA, Arion Sayão. O princípio da proteção em xeque. São Paulo: LTr, 2003.
} 
Para Cássio Mesquita Barros, a Declaração III da Carta del Lavoro está, praticamente transcrita no art. 138 da Carta de 1937:

“(..).

A greve e o lockout eram considerados 'recursos anti-sociais, nocivos ao trabalho e ao capital e incompatíveis com os superiores interesses da produção nacional' (art. 139, in fine, da Carta de 1937).

O Decreto-lei $\mathrm{n}^{\circ}$ 1.402, de 5.7.1939 complementou a Carta Constitucional. Com essa medida legislativa, o sindicato passou a sofrer 'um controle realmente minucioso', segundo o presidente da comissão que elaborou o respectivo anteprojeto e também seu relator geral, o jurista e sociólogo Oliveira Viana, que sustentava na Exposição de Motivos, apresentada à sanção presidencial:

'(...) com a instituição deste registro, toda a vida das associações profissionais passará a gravitar em torno do Ministério do Trabalho: nele nascerão; com ele crescerão; ao lado dele se desenvolverão; nele se extinguirão.'

Incorporado o Decreto-lei $\mathrm{n}^{\circ} 1.402$ à Consolidação das Leis do Trabalho, de 1943, as diretrizes sobre organização sindical de caráter corporativo nele consagradas, prevalecem, em suas linhas fundamentais, até hoje, na Constituição de 1988."38

O dispositivo supra referido mostra a influência do regime italiano sobre a legislação trabalhista brasileira:

"O modelo corporativo italiano foi montado sobre a estrutura sindical: o
sindicato era a célula elementar do sistema, o ponto de início e de
suporte das corporações.
O sindicato era responsável pela defesa dos interesses da categoria (à
luz do interesse geral); a corporação, por sua vez, cuidava apenas do
interesse geral. Ela era um órgão misto (isto é, unia empregados e
empregadores) e interprofissional, que deveria conciliar os interesses
das categorias que a compunham - era ela um órgão de disciplina, de
unidade, encarregada de promover a síntese dos diferentes interesses
das categorias..."

Para Otávio Augusto Custódio de Lima, a intervenção na organização sindical brasileira teve suas bases sustentadas pelos seguintes pilares:

\footnotetext{
${ }^{38}$ BARROS, Cássio Mesquita. op. cit.

${ }^{39}$ CUNHA, Rodrigo Giostri da. Análise do modelo corporativista italiano. Revista do Departamento de Direito do Trabalho e da Seguridade Social, São Paulo, v. 1, n. 2, jul./dez. 2006.
} 
“(...) a) implantação do princípio da unicidade sindical com constituição de um único sindicato representativo da categoria profissional e econômica; b) integração do sindicato em um sistema de relacionamento hierárquico com federações e confederações, constituídas respectivamente por categorias e ramos de atividade econômica; c) sujeição das entidades sindicais ao Ministério do Trabalho, através de: registro, fiscalização, intervenção, destituição de diretores, expulsão de associados; d) predeterminação das funções a serem exercidas pelos sindicatos; e) manutenção das entidades sindicais através de imposto criado pelo Estado."

Em $1^{\circ}$ de maio de 1943, foi aprovada a Consolidação das Leis do Trabalho - CLT (Decreto-Lei 5.452), sob o amparo da Constituição de 1937, elaborada, consoante seu artigo $1^{\circ}$, com as normas que regulam as relações individuais e coletivas de trabalho. Todavia, no modelo corporativista eleito por Getúlio Vargas, a ação sindical ainda se encontrava vinculada ao controle do Estado.

Para Amauri Mascaro do Nascimento, "a publicação da Consolidação das Leis do Trabalho, em nada contribuiu para mudar o que havia, não passando de mera reunião de textos já existentes, com algumas pinceladas pouco ou quase nada inovadoras". 41

Em 1967, sob o regime militar, foi promulgada uma nova Constituição. Nessa Carta, a estrutura sindical não foi tratada de maneira diferente do que já existia, exceção feita à obrigatoriedade de voto nas eleições sindicais conforme seu art. 159: "É livre a associação profissional ou sindical; a sua constituição, a representação legal nas convenções coletivas de trabalho e o exercício de funções delegadas de Poder Público serão regulados em lei.

$\S 1^{\circ}$ - Entre as funções delegadas a que se refere este artigo, compreende-se a de arrecadar, na forma da lei, contribuições para o custeio da atividade dos órgãos sindicais e profissionais e para a execução de programas de interesse das categorias por eles representadas.

$\S 2 .^{\circ}$ - É obrigatório o voto nas eleições sindicais.

\footnotetext{
${ }^{40}$ LIMA, Otávio Augusto Custódio de. Negociação coletiva: um caminho para a flexibilização. Projeto NEG. núcleo de Estudos sobre a Globalização. Disponível em: $<$ http://globalization.sites.uol.com.br/negociao.htm>. Acesso em: 21 nov. 2010.

${ }^{41}$ NASCIMENTO, Amauri Mascaro. Compêndio de direito sindical. 5. ed. São Paulo: LTr, 2008. p. 130.
} 
Por fim, a Constituição promulgada em 1988 não alcançou êxito em atenuar os princípios corporativos presentes na estrutura sindical brasileira o que promoveria a modernização e sintonização do sistema de representação coletiva do Brasil com o que se passa nos países que desfrutam de visões modernas sobre o direito coletivo, inclusive aqueles que adotaram o corporativismo em seu passado, como Itália e Alemanha.

Nesse sentido, Arnaldo Süssekind leciona:

"Convém assinalar apenas que o estatuído no art. $8^{\circ}$., resultou de acordo exótico entre parlamentares do centro e algumas lideranças sindicais de trabalhadores e empresários. Daí ter consagrado plena autonomia sindical e, ao mesmo tempo, estabelecido o monopólio de representação sindical por categoria, que afronta o princípio da liberdade sindical. Por outro lado, possibilitou a contribuição sindical compulsória e ainda conferiu um poder tributário anômalo aos sindicatos. ${ }^{, 42}$

A Constituição de 1988, em vigência nos dias de hoje, traz matéria trabalhista em seus artigos $7^{\circ}, 8^{\circ}$ e $9^{\circ}$, dispondo sobre garantias fundamentais de direito individual e direito coletivo do trabalho:

“Art. $8^{\circ}$ É livre a associação profissional ou sindical, observado o seguinte:

I - a lei não poderá exigir autorização do Estado para a fundação de sindicato, ressalvado o registro no órgão competente, vedadas ao Poder Público a interferência e a intervenção na organização sindical;

II - é vedada a criação de mais de uma organização sindical, em qualquer grau, representativa de categoria profissional ou econômica, na mesma base territorial, que será definida pelos trabalhadores ou empregadores interessados, não podendo ser inferior à área de um Município;

III - ao sindicato cabe a defesa dos direitos e interesses coletivos ou individuais da categoria, inclusive em questões judiciais ou administrativas;

IV - a assembléia geral fixará a contribuição que, em se tratando de categoria profissional, será descontada em folha, para custeio do sistema confederativo da representação sindical respectiva, independentemente da contribuição prevista em lei;

V - ninguém será obrigado a filiar-se ou a manter-se filiado a sindicato;

\footnotetext{
${ }^{42}$ SÜSSEKIND, Arnaldo; MARANHÃO, Délio; VIANNA, Segadas; TEIXEIRA FILHO, João de Lima.
} op. cit., p. 1069. 
VI - é obrigatória a participação dos sindicatos nas negociações coletivas de trabalho;

VII - o aposentado filiado tem direito a votar e ser votado nas organizações sindicais;

VIII - é vedada a dispensa do empregado sindicalizado a partir do registro da candidatura a cargo de direção ou representação sindical e, se eleito, ainda que suplente, até um ano após o final do mandato, salvo se cometer falta grave nos termos da lei.

Parágrafo único. As disposições deste artigo aplicam-se à organização de sindicatos rurais e de colônias de pescadores, atendidas as condições que a lei estabelecer.

Art. $9^{\circ}$ É assegurado o direito de greve, competindo aos trabalhadores decidir sobre a oportunidade de exercê-lo e sobre os interesses que devam por meio dele defender.

$\S 1^{\circ}$ - A lei definirá os serviços ou atividades essenciais e disporá sobre $\mathrm{o}$ atendimento das necessidades inadiáveis da comunidade.

$\S 2^{\circ}$ - Os abusos cometidos sujeitam os responsáveis às penas da lei.

O sindicalismo brasileiro dos anos 80 ficou conhecido como "novo sindicalismo" em contraposição ao sindicalismo das décadas 1950 e 1960, quando a maioria das diretorias sindicais era governista. Ao longo da década de 1980, o modo de funcionamento e de organização do sindicalismo oficial se modificou.

"Para Antunes, o aumento das 'greves por empresas' no decorrer dos anos 80 indicava, no seio do movimento sindical brasileiro, o avanço da tendência do 'sindicalismo de resultados' (o 'sindicalismo de resultados' assumiria uma expressão política clara com a criação da Força Sindical, em 1991). Por outro lado, no interior da própria CUT, sob a era neoliberal, desdobrar-se-ia uma tendência similar, de cariz neocorporativo, com o sindicalismo de participação, que privilegia estratégias propositivas; um novo sindicalismo, cada vez mais defensivo, disposto a incluir, em sua pauta de resistência, a parceria com o capital. Nos anos 90, sob o novo complexo de reestruturação produtiva, tender-se-ia a privilegiar, cada vez mais, as 'greves por empresas', demonstrando o predomínio - inclusive no interior do sindicalismo da CUT - da política do 'sindicalismo de resultados"."43

Atualmente, a atuação dos sindicatos dá especial ênfase ao diálogo e à negociação coletiva. Na lição de Rodrigues e Ramalho, "O 'novo sindicalismo', principalmente do $\mathrm{ABC}$ [região metropolitana da capital do estado de São Paulo], que

\footnotetext{
${ }^{43}$ ALVES, Giovanni. Do "novo sindicalismo” à "concertação social”: ascensão (e crise) do sindicalismo no Brasil (1978-1998). Revista de Sociologia e Política, Curitiba, n. 15, p. 115, nov. 2000.
} 
apareceu na cena pública no final da década de 70, em oposição ao regime militar, reivindicando melhores salários e melhores condições de trabalho, começou paulatinamente a mudar sua estratégia e sua ação no decorrer da década atual. Diferentemente do período anterior, hoje, a pauta central dos sindicatos é a defesa do emprego, a participação nos resultados, a flexibilização da jornada de trabalho, a discussão de mudanças na gestão e organização do trabalho, em outras palavras, a preocupação em atenuar os efeitos da reestruturação e buscar uma alternativa negociada sobre as mudanças no trabalho". ${ }^{4}$

${ }^{44}$ RODRIGUES, Iram Jácome; RAMALHO, José Ricardo. Dilemas do sindicalismo na Inglaterra e no Brasil: uma abordagem comparativa. Texto apresentado ao XXII ENCONTRO ANUAL DA ASSOCIAÇÃO DE PÓS-GRADUAÇÃO EM CIÊNCIAS SOCIAIS (ANPOCS). Caxambú, MG, 27 a 30 de outubro de 1998. Disponível em: <bibliotecavirtual.clacso.org.ar/ar/libros/anpocs/jacome.rtf>. Acesso em: 14 out. 2011. 


\section{MERCADO DE TRABALHO $X$ DESENVOLVIMENTO ECONÔMICO}

\subsection{Globalização e mercado de trabalho}

O trabalho é um componente essencial na formação do indivíduo. É determinante em seu processo de humanização, além de constituir elemento fundamental na construção da dignidade do homem, pois favorece seu aperfeiçoamento moral e fortalece as relações sociais. O trabalho está presente na vida do homem desde sempre. Além disso, para a grande maioria da população, a única forma de garantir sua subsistência é obter dinheiro por meio do trabalho, o que torna essa atividade indispensável na vida de quase todos os seres humanos. Ainda aqueles que vivem de renda ou os próprios empregadores têm sua vida financeira ligada indiretamente ao mercado de trabalho, pois seus investimentos ou empresas somente darão lucro se trabalhadores executarem suas funções, forem remunerados por isso e consumirem produtos para sua sobrevivência.

Karl Marx, em sua célebre obra, $O$ Capital, diz que o trabalho para o homem, "Põe em movimento as forças naturais de seu corpo - braços e pernas, cabeça e mãos -, a fim de apropriar-se dos recursos da natureza, imprimindo-lhes forma útil à vida humana. Atuando assim sobre a natureza externa e modificando-a, ao mesmo tempo em que modifica sua própria natureza...". 45

O senso comum indica que, trabalhando, o homem pode viver melhor e assim concretizar a sua dignidade ao se perceber inserido socialmente e realizado pessoalmente. A par de considerações sobre o efeito psicológico do trabalho sobre a vida daqueles que o executam, o relevante é que a dignidade humana, na prática, provém da condição social que a pessoa conquista para levar sua vida e, conforme já apontado, é do trabalho que os homens obtêm dinheiro para garantir um padrão de vida, qualquer que seja, e, dessa forma, ter dignidade.

\footnotetext{
${ }^{45}$ MARX, Karl. O capital: crítica da economia política. Rio de Janeiro: Civilização Brasileira, 2008. Livro 1, v. 2, p. 211.
} 
Sarlet $^{46}$ :

Sobre o princípio da dignidade da pessoa humana, ensina Ingo Wolfgan

“...Temos por dignidade da pessoa humana a qualidade intrínseca e distintiva reconhecida em cada ser humano que o faz merecedor do mesmo respeito e consideração por parte do Estado e da comunidade, implicando, neste sentido, um complexo de direitos e deveres fundamentais que assegurem a pessoa tanto contra todo e qualquer ato de cunho degradante e desumano, como venham a lhe garantir as condições existenciais mínimas para uma vida saudável, além de propiciar e promover sua participação ativa e co-responsável nos destinos da própria existência e da vida em comunhão com os demais seres humanos".

As lutas sociais por condições melhores de vida levaram à incorporação de diversos direitos sociais nas Constituições de diversos países. Nesse sentido, cresceu a valorização dos princípios relativos ao Direito do Trabalho. Estes foram alçados ao rol das garantias constitucionais, apoiando-se em regras de ordem econômica, norteadas pelos fundamentos de valorização do trabalho humano e da livre iniciativa, ${ }^{47}$ com a finalidade de preservar e garantir a dignidade da pessoa humana, coibindo a prática de abuso do poder econômico.

Foi por meio da consagração dos direitos sociais que, aos poucos, o equilíbrio de poder nas relações de trabalho começou a ser alterado. José Afonso da Silva, por exemplo, entende que a livre iniciativa somente é legítima quando praticada no interesse da justiça social:

\begin{abstract}
"num contexto de uma Constituição preocupada com a realização da justiça social (o fim condiciona os meios), não pode significar mais do que liberdade de desenvolvimento da empresa no quadro estabelecido pelo poder público, e, portanto, possibilidade de gozar das facilidades e necessidade de submeter-se às limitações postas pelo mesmo. É legítima, enquanto exercida no interesse da justiça social. Será ilegítima, quando exercida com objetivo no puro lucro e realização pessoal do empresário." 48
\end{abstract}

\footnotetext{
${ }^{46}$ SARLET, Ingo Wolfgang. Dignidade da pessoa humana e direitos fundamentais. 4. ed. Porto Alegre: Livr. do Advogado, 2006. p. 60.

${ }^{47}$ Constituição Federal, Art. 170. A ordem econômica, fundada na valorização do trabalho humano e na livre iniciativa, tem por fim assegurar a todos existência digna, conforme os ditames da justiça social..."

${ }^{48}$ SILVA, José Afonso da. Curso de direito constitucional positivo. 23. ed. São Paulo: Malheiros Ed., 2004. p. 774.
} 
Seguindo essa linha de entendimento, a busca do lucro só seria legítima se inserida num contexto maior no qual a aspiração maior seria a distribuição da riqueza e não somente a sua acumulação pessoal. Porém, o grande desafio reside em como equilibrar o estímulo ao desenvolvimento dos negócios, que depende de capital acumulado para investimentos, e o nível de dignidade que se almeja para a população dependente do trabalho.

A Declaração Universal dos Direitos dos Humanos reconhece o trabalho como direito humano em seu artigo XXIII:

1 Toda pessoa tem direito ao trabalho, à livre escolha de emprego, a condições justas e favoráveis de trabalho e à proteção contra o desemprego.

2. Toda pessoa, sem qualquer distinção, tem direito a igual remuneração por igual trabalho.

3. Toda pessoa que trabalhe tem direito a uma remuneração justa e satisfatória, que lhe assegure, assim como à sua família, uma existência compatível com a dignidade humana, e a que se acrescentarão, se necessário, outros meios de proteção social. ${ }^{49}$

4. Toda pessoa tem direito a organizar sindicatos e neles ingressar para proteção de seus interesses. (grifo nosso)

O momento econômico por que passa a sociedade global atualmente, revela a predominância de políticas governamentais voltadas à valorização do capital. Nesse panorama, o mundo do trabalho vem sendo pressionado constantemente a passar por grandes transformações que se apresentam sob diversos aspectos como a flexibilização, a necessidade de lidar com os efeitos do desemprego e a própria globalização da economia, situações estas que crescem com intensidade e são inescapáveis.

Roberto Basilone Leite leciona que "com a queda dos nacionalismos e o início da decadência do socialismo real, a partir do final da Segunda Grande Guerra, o processo de globalização, que havia permanecido suspenso até então, ingressou em sua derradeira fase de consolidação. Uma das características dessa fase é a superação dos

\footnotetext{
${ }^{49}$ DECLARAÇÃO UNIVERSAL DOS DIREITOS HUMANOS. Adotada e proclamada pela resolução 217
} A (III) da Assembléia Geral das Nações Unidas em 10 de dezembro de 1948. 
paradigmas da modernidade e o advento da pós-modernidade". ${ }^{50}$ Nesse sentido, os paradigmas da modernidade seriam o Direito do Trabalho legislado como o conhecemos no Brasil e a pós-modernidade, a relação trabalhista flexibilizada.

Com a nova configuração do sistema de produção, na qual o desenvolvimento e a inovação tecnológica são a grande ferramenta para o crescimento econômico, o trabalho passa a exigir novos padrões de produção. Dessa maneira, a desregulamentação do mercado de trabalho atinge tanto os trabalhadores que gozavam da estabilidade no emprego, quanto os que estão ingressando em seu primeiro emprego. Essa desregulamentação refere-se a "uma nova postura do Estado diante das relações entre capital e trabalho e ocorre com o implemento de alterações na legislação trabalhista". ${ }^{51}$ Segundo os autores, as causas da desregulamentação baseiam-se em acontecimentos sociais, políticos e econômicos.

Posicionando-se em relação ao desfecho do conflito entre o capital e o trabalho, já em 1963, o Papa João XXIII editou a Carta Enciclica Pacem in Terris, enfatizando os direitos inerentes ao campo econômico e ressaltando as condições de trabalho e a dignidade da pessoa humana:

"Direitos inerentes ao campo econômico

18. No que diz respeito às atividades econômicas, é claro que, por exigência natural, cabe à pessoa não só a liberdade de iniciativa, senão também o direito ao trabalho.

19. Semelhantes direitos comportam certamente a exigência de poder a pessoa trabalhar em condições tais que não se lhe minem as forças físicas nem se lese a sua integridade moral, como tampouco se comprometa o são desenvolvimento do ser humano ainda em formação. Quanto às mulheres, seja-lhes facultado trabalhar em condições adequadas às suas necessidades e deveres de esposas e mães.

20. Da dignidade da pessoa humana deriva também o direito de exercer atividade econômica com senso de responsabilidade. Ademais, não podemos passar em silêncio o direito à remuneração do trabalho conforme aos preceitos da justiça; remuneração que, em proporção dos recursos disponíveis, permita ao trabalhador e à sua família um teor de vida condizente com a dignidade humana. A esse respeito nosso

\footnotetext{
${ }^{50}$ LEITE, Roberto Basilone. Desregulamentação, flexibilização e reconstrução do ordenamento trabalhista: o trabalhador entre o neoliberalismo e o garantismo. Revista LTr, São Paulo, ano 66, n. 12, p. 1414, dez. 2002.

${ }^{51}$ SULZBACH, Mayra Taiza; DENARDIN, Valdir Frigo. O impacto da regulamentação do mercado de trabalho frente a fragilidade orçamentária e do emprego nos municípios do litoral do Paraná. Universidade Federal do Rio Grande do Norte, CCHLA. Disponível em: <http://www.cchla.ufrn.br>. Acesso em: 15 abr. 2010.
} 
predecessor de feliz memória Pio XII afirma: 'Ao dever pessoal de trabalhar, inerente à natureza, corresponde um direito igualmente natural, o de poder o homem exigir que das tarefas realizadas lhe provenham, para si e seus filhos, os bens indispensáveis à vida: tão categoricamente impõe a natureza a conservação do homem.". ${ }^{2}$

Essa encíclica traz um exemplo do ideário sobre o equilíbrio que se pretende fazer existir entre os objetivos do capitalista e as necessidades dos trabalhadores. Nesse ponto, pode-se perceber claramente o papel do Direito do Trabalho como meio para se atingir esse equilíbrio, pois como não é natural a harmonização de interesses entre o detentor dos meios de produção e os que trabalham para ele, fazse necessário ter a legislação trabalhista como um marco regulatório.

Flexibilização do trabalho, terceirização e cooperativização, por exemplo, são novas formas de organização do trabalho, baseadas num modelo toyotista de produção. ${ }^{53}$

A automatização é considerada o primeiro elemento desse modelo. Trata-se da utilização de máquinas capazes de parar automaticamente quando surgem problemas. Assim o trabalhador que até então era treinado para desenvolver seu trabalho em uma única máquina pode se responsabilizar por várias, o que diminuiria a quantidade de trabalhadores necessários numa linha de montagem.... ${ }^{54}$

Para que quaisquer dessas formas de organização do trabalho prosperem num contexto de justiça social, é necessário que os trabalhadores consigam impor os princípios protetivos das relações trabalhistas aos tomadores de seus serviços. Do contrário, sempre haverá a possibilidade de que, na busca natural pela maximização de seus lucros, o capitalista minimize os custos piorando as condições de trabalho.

\footnotetext{
${ }^{52}$ CARTA Encíclica Pacem in Terris do Sumo Pontífice Papa João xxiii. A Paz de Todos os Povos na Base da Verdade, Justiça, Caridade e Liberdade. Disponível em: $<$ http://www.vatican.va/holy_father/john_xxiii/encyclicals/documents/hf_jxxiii_enc_11041963_pacem_po.html>.

${ }^{53}$ SULZBACH, Mayra Taiza; DENARDIN, Valdir Frigo. op. cit.“... o modelo de produção fordista ao ser substituído pelo modelo de produção toyotista reduz o emprego formal, marca registrada do fordismo que controlava o chão da fabrica centralizando os trabalhadores e a produção. O emprego formal já não se faz necessário, a estabilidade não pode mais ser garantida pelo empregador, todo trabalhador é estimulado a ser empregador da sua força de trabalho.

${ }^{54}$ FUTATA, Marli Delmônico de Araújo. Breve análise sobre o toyotismo: modelo japonês de produção. Revista Espaço Acadêmico, n. 47, abr. 2005. Disponível em: <http://www.espacoacademico.com.br/047/47cfutata.htm>. Acesso em: 18 jul. 2011.
} 
Nesse processo, diminuição de salários é um fator altamente manipulável devido à abundância da oferta de mão-de-obra. Segundo Ricardo Antunes:

\begin{abstract}
"Opondo-se ao contra-poder que emergia das lutas sociais, o capitalismo iniciou um processo de reorganização das suas formas de dominação societal, não só procurando reorganizar em termos capitalistas o processo produtivo, mas procurando gestar um processo de recuperação da hegemonia nas mais diversas esferas da sociabilidade. Fez isso, por exemplo, no plano ideológico, por meio do culto de um subjetivismo e de um ideário fragmentador que faz apologia ao individualismo exacerbado contra as formas de solidariedade e de atuação coletiva e social",55
\end{abstract}

Desse modo, percebe-se legítima a resistência a iniciativas que retirem grande parte da proteção do direito do trabalho para permitir que as condições de trabalho sejam negociadas ao invés de legisladas. À medida que a lei trabalhista deixa de ser aplicada em favor da negociação individual ou até mesmo coletiva, nasce a insegurança de que os trabalhadores não vão conseguir garantir condições dignas de trabalho sem que o Estado as imponha por meio da lei.

Pode-se afirmar que as relações de trabalho desde meados do século passado e no atual, estão assinaladas pela competitividade e pela globalização. A integração entre os países, marcada por um intenso fluxo de serviços e produtos, avanços tecnológicos, entre outros, não é vista com positividade por Octavio Ianni, por exemplo:

“... Nós estamos vivendo uma globalização que é a globalização de cima para baixo. Que é das grandes corporações, dos grandes negócios, dos grandes mercados. E essa globalização é um fato irreversível e danoso. Gravemente danoso para todo mundo, estamos vendo. Agora, sendo o fato irreversível, o que nos cabe é reconhecer que é um fato irreversível e batalhar para que haja uma globalização de baixo para cima, para que os povos, os grupos, as sociedades, as nações, possam entrar nesse espetáculo fantástico que é a sociedade mundial."

\footnotetext{
${ }^{55}$ ANTUNES, Ricardo. Os sentidos do trabalho: ensaio sobre a afirmação e a negação do trabalho. São Paulo: Boitempo, 2002. p. 48.

${ }^{56}$ RODA Viva - Octavio Ianni. Roda viva - octavio ianni.doc - UFSC. Entrevista para Paulo Markun. Biblioteca Práxis - Rede Social. Disponível em: <bib.praxis.ufsc.br>.
} 
Sendo a globalização um fruto da integração comercial entre as nações, é natural que ocorra a partir do topo do capitalismo e não de sua base, sendo realmente necessário, como apontado por Ianni, que os trabalhadores tenham como lidar com seus efeitos tanto positivos, quanto negativos.

Maria Cristina Cacciamali enxerga dois aspectos relevantes no fenômeno da globalização:

\begin{abstract}
"O contexto da globalização, se, por um lado, encerra elementos que limitam a ação do Estado Nacional, por exemplo, no momento presente, no caso da seleção e implementação de uma determinada política econômica, por outro lado, requer sua ação ativa, nos moldes citados anteriormente. $\mathrm{O}$ objetivo nesse caso é filtrar determinados efeitos provocados pela maior exposição ao exterior e pela maior integração das economias. Alguns desses efeitos podem ser perversos, por exemplo, associados à perda da identidade cultural; outros podem ser muito rápidos, como a destruição de determinados segmentos empresariais e ramos de atividade domésticos intensivos em mão-deobra que não dispuseram da oportunidade de se reestruturar em patamares tecnológico e de produtividade superiores; e outros podem ser positivos, como maior competição nos mercados e aumento nos níveis de produtividade. O Estado Nacional, dessa forma, se mantém como palco de disputas e de conflitos com relação aos interesses e representações de diferentes grupos sociais, sendo um ator primordial na configuração da inserção internacional e do padrão de crescimento econômico implementado, bem como dos resultados sociais e da distribuição de renda". ${ }^{57}$
\end{abstract}

Para a autora, ao mesmo tempo em que o crescimento econômico advindo da globalização pode beneficiar as condições de funcionamento dos pequenos negócios, também "pode implicar deterioração nas condições de vida de determinados estratos. Esse é um dos motivos que justificam a execução de políticas públicas específicas para a sua promoção econômica". 58

"A globalização se refere essencialmente a este processo de alongamento, na medida em que as modalidades de conexão entre diferentes regiões ou contextos sociais se enredaram através da superfície da Terra como um todo.

${ }^{57}$ CACCIAMALI, Maria Cristina. Globalização e processo de informalidade. Economia e Sociedade, UNICAMP, Instituto de Economia, Campinas, n. 14, p. 170, jun. 2000. Disponível em: $<$ http://www.eco.unicamp.br/docdownload/publicacoes/instituto/revistas/economia-e-sociedade/V9-F1S14/06-Cacciamali.pdf>. Acesso em: 02 fev. 2011.

${ }^{58}$ CACCIAMALI, Maria Cristina. op. cit., p. 171. 
A globalização pode assim ser definida como a intensificação das relações sociais em escala mundial, que ligam localidades distantes de tal maneira que acontecimentos locais são modelados por eventos ocorrendo a muitas milhas de distância e vice-versa. Este é um processo dialético porque tais acontecimentos locais podem se deslocar numa direção anversa às relações muito distanciadas que os modelam"59

No campo do trabalho, há quem entenda que é necessário permitir maior negociação sobre as condições em que se estabelecem as relações de trabalho a fim de assimilar os efeitos da globalização e, há quem considere impensável abrir mão do padrão mínimo representado pela legislação trabalhista.

Para Lúcio Rodrigues de Almeida é inadmissível e "politicamente perigoso que o mundo seja impulsionado pelas leis do mercado". ${ }^{60}$

Se por um lado, a globalização e a competitividade têm contribuído para as mudanças ocorridas nas empresas, por outro, esses fenômenos resultam em duas vertentes negativas: a queda dos salários e o aumento do desemprego movido pelo crescimento tecnológico, que requer do trabalhador nova postura e novos conhecimentos.

\begin{abstract}
"Para alcançar maior competitividade, as empresas passaram a adotar novos métodos de produção, administração e comercialização, buscando sempre mais eficiência produtiva, inovações e uma maior qualidade para seus produtos e serviços, com grandes aumentos de produtividade que, freqüentemente, geraram menores necessidades de mão-de-obra. O próprio relacionamento com os empregados também passou a sofrer alterações, com o objetivo de obter maior produtividade e de delegar autonomia de decisão, com isso proliferando métodos específicos como a terceirização, ou seja, a contratação externa de produção e de serviços antes realizados pelas próprias empresas. Houve também grandes mudanças nas qualificações exigidas dos trabalhadores, os quais passaram por programas de adaptação ou, desempregados, buscaram novas ocupações. Nesse processo, a indústria e a agricultura continuaram perdendo participação no volume da mãode-obra empregada, crescendo, entretanto, a participação do setor de serviços, mas novamente impondo novas necessidades em termos de qualificações." ${ }^{\text {,61 }}$
\end{abstract}

\footnotetext{
${ }^{59}$ GIDDENS, Anthony. As consequências da modernidade. São Paulo: Ed. UNESP, 1991. p. 69-70. Books Google. Disponível em: <http://books.google.com.br>. Acesso em: 02 maio 2011.

${ }^{60}$ ALMEIDA, Lúcio Rodrigues de. As leis imperativas e a CLT. LTr, Suplemento trabalhista, São Paulo, n. 179, p. 1016, 1994.

${ }^{61}$ MACEDO, Roberto. Seu diploma, sua prancha. São Paulo: Saraiva, 1998. p. 137.
} 
Na lição de Patrícia Tuma Martins Bertolin, a revolução tecnológica contribuiu para achatamento de salários, para o desemprego tecnológico e o aumento das desigualdades de renda:

"O panorama instaurado por essa Revolução da Tecnologia é mais ou
menos o seguinte: salários achatados, ritmo frenético no ambiente de
trabalho, rápido crescimento do trabalho contingencial de meio período,
desemprego tecnológico, aumento da disparidade de renda entre ricos e
pobres e dramático encolhimento da classe média.

As inovações tecnológicas da última década permitiram ao sistema capitalista expandir-se, transformando substancialmente as condições de produção em todo o mundo, sendo utilizadas pela ideologia neoliberal para sustentar o império do mercado. Resulta da construção neoliberal, em última instância, a inaptidão para se utilizar os benefícios do progresso tecnológico para a melhoria da qualidade de vida da sociedade como um todo, com escasso investimento administrativo em setores prioritários como educação, saúde e seguridade social, assim como a retração do Estado como promotor de atividades produtivas." ${ }^{62}$

Para Luiz Gonzaga Ribeiro Neto, a globalização e o crescimento tecnológico também trouxeram para as empresas alguns obstáculos, pois, inseridas num ambiente competitivo, as empresas são impelidas a criar novos "sistemas de informação que acompanhem o ritmo das transformações." ${ }^{\prime 63}$

Na ótica de Manuel Castells, o processo de globalização da economia não fez com que o mercado de trabalho se tornasse igualmente global:

“...havendo uma economia global, também devem existir um mercado
de trabalho e uma força de trabalho global. Entretanto, como acontece
com muitas declarações óbvias, consideradas em seu sentido literal,
essa é empiricamente incorreta e analiticamente enganosa, embora o
capital flua com liberdade nos círculos eletrônicos das redes financeiras
globais, o trabalho ainda é muito delimitado (e continuará assim no
futuro previsível) por instituições, culturas, fronteiras políticas e
xenofobia. Contudo, as migrações internacionais estão aumentando,
numa tendência de longo prazo que contribui para a transformação da

${ }^{62}$ BERTOLIN, Patrícia Tuma Martins. Algumas reflexões sobre os impactos do comércio internacional sobre o mundo do trabalho. Revista do Departamento de Direito do Trabalho e da Seguridade Social, São Paulo, v. 2, n. 3, p. 53-60, jan./jun. 2007.

${ }^{63}$ RIBEIRO NETO, Luiz Gonzaga. Os impactos da tecnologia de informação nas organizações: uma visão política $R$. Un. Alfenas, Alfenas, n. 5, p. 95-101, 1999. Disponível em: <http://www.unifenas.br/pesquisa/download/ArtigosRev1_99/pag95-101.pdf>. Acesso em: 04 abr. 2010. 
força de trabalho, embora de uma maneira mais complexa do que a apresentada pela ideia de um mercado de trabalho global" ${ }^{64}$

Nesse cenário de globalização, o domínio da informação e das novas tecnologias valorizam a competitividade ao mesmo tempo em que reduzem a oferta de empregos, pois há certa desvalorização do trabalhador de um modo geral, embora haja enaltecimento da mão-de-obra qualificada.

Essa nova realidade econômica global atinge as relações de trabalho muitas vezes por meio da redução dos benefícios dos trabalhadores. As indústrias estão voltadas para a terceirização de suas atividades, para a contratação de mão-de-obra mais barata a fim de obter resultados positivos nos custos de seus processos de produção.

"As empresas multinacionais, antigas e novas, experimentam também
mudanças, na busca por competitividade. Transferem fábricas de um
país para o outro, criam produtos globalizados, cujos componentes são
oriundos das mais diversas nacionalidades. Os Estados nacionais
oferecem incentivos às empresas transnacionais, principalmente nos
países do terceiro mundo, onde se pagam baixos salários, o que lhes dá
melhores condições de competitividade, às custas de um dumping
social."

Segundo Patrícia Tuma Martins Bertolin, "o acirramento da competição internacional tem propiciado uma maior utilização dos chamados contratos de trabalho 'atípicos' e diminuído consideravelmente as oportunidades de emprego no setor formal". ${ }^{66}$ Continua, a autora, afirmando:

"Os novos processos produtivos resultantes da incorporação de
tecnologias de ponta têm sido responsáveis por notável redução do
número de empregos, fenômeno a que os especialistas costumam
chamar de desemprego tecnológico, que se agrava com a utilização do
trabalho temporário e da terceirização, que constituem a maior parte da
força de trabalho contingencial. Sua própria existência age como
redutor dos salários dos trabalhadores fixos". ${ }^{67}$

${ }^{64}$ CASTELLS, Manuel. A sociedade em rede. Tradução Roneide Venancio Majer com a colab. de Klauss Brandini Gerhardi. 8. ed. total. rev. e ampl. São Paulo: Paz e Terra, 1999. v. 1, p. 297.

${ }^{65}$ BERTOLIN, Patrícia Tuma Martins. op. cit.

${ }^{66}$ Id. Ibid.

${ }^{67}$ Id. Ibid. 
O Direito do Trabalho, neste contexto, é o que mais está sujeito às transformações. Quanto a essa questão, Amauri Mascaro Nascimento leciona que não é possível ao Direito do Trabalho alcançar vigor "sem considerar os fatores desencadeados dos impactos que vem sofrendo, as transformações decorrentes do avanço da tecnologia, a internacionalização dos mercados, a competitividade entre as empresas, a necessidade de redução dos custos com o trabalho e as modificações do papel do Estado na ordem econômica social". ${ }^{6}$

Com o objetivo de preservar os empregos, “...os países têm recorrido à estratégia da Flexibilização do Direito do Trabalho, que, consoante o ensinamento de Jean-Claude Javillier, apresenta três possíveis enfoques: uma flexibilidade de proteção, inerente à concepção clássica do Direito do Trabalho, fixando normas e princípios mais favoráveis ao trabalhador; uma flexibilidade de adaptação, autorizando derrogações in pejus; e uma flexibilidade de desregramento (ou Desregulamentação, como preferem os juslaboralistas pátrios), ficando a regulação das relações de trabalho a cargo de seus próprios sujeitos". 69

Todavia, como já aventado, em países cujo Direito do Trabalho ainda conta com viés corporativista como o caso Brasileiro, instala-se insegurança ao se imaginar que os direitos trabalhistas garantidos em lei podem ser afastados da relação de trabalho por meio de negociação. Não se pode comparar a experiência brasileira na necessidade de reavaliar o papel do Direito do Trabalho com a de países europeus tais como França, Alemanha e Inglaterra, nos quais há liberdade sindical plena desde o pósguerra. Sabe-se que para equilibrar o poder econômico do empregador ao negociar as condições de trabalho de grande parte da mão-de-obra (excetuando-se trabalhadores altamente qualificados e executivos), é fundamental o papel de sindicatos livres e com suficiente representatividade, por exemplo.

Entretanto, como a representatividade sindical no Brasil é precária, dada a presença de unicidade legal e do financiamento por meio de imposto, torna-se evidente o porquê de boa parte da doutrina jurídica rechaçar iniciativas que afastem o mínimo previsto em lei das relações trabalhistas, deixando que as condições sejam estipuladas por meio da autonomia da vontade dos contratantes.

\footnotetext{
${ }^{68}$ NASCIMENTO, Amauri Mascaro (Coord.). A transição do direito do trabalho no Brasil: estudos em homenagem a Eduardo Gabriel Saad. São Paulo: LTr, 1999. p. 15.

${ }^{69}$ JAVILLIER, Jean-Claude. Manual de direito do trabalho. São Paulo: LTr, 1988. p. 55-58 apud BERTOLIN, Patrícia Tuma Martins. op. cit.
} 


\subsection{O emprego no setor de serviços}

O modelo de produção, assinalado pelas mudanças na organização do trabalho vem causando uma nova forma de reorganização do mercado de trabalho. As empresas procurando diminuir seus custos buscam, como estratégia, a contratação no setor de Serviços $^{70}$, para a realização de suas atividades. Em decorrência disto, atualmente o mercado convive com significativo aumento desta modalidade de mãode-obra.

$\mathrm{Na}$ década de 80, os países chamados "subdesenvolvidos" eram caracterizados pela "hipertrofia do setor terciário" de suas economias, fenômeno que revelava um setor industrial (secundário) incipiente, o que levava a mão-de-obra a buscar empregos no setor de serviços tornando-o um precário motor da economia, uma vez que não se considerava haver produção de bens por meio exclusivamente da prestação de serviços. ${ }^{71}$ Já nos países economicamente desenvolvidos, o que se assistiu a partir da década de 80 foi a TERCIARIZAÇÃO da economia.

O crescimento do setor de serviços na economia global, não se deu de maneira autônoma, "mas meramente como conseqüência dos ganhos de produtividade do setor industrial". 72

O conceito de produtividade, correntemente definido como a razão entre o produto e os insumos, é utilizado na literatura econômica como uma medida que reflete uma série de atributos necessários à riqueza e ao

\footnotetext{
70،...Atualmente as Contas Nacionais e a literatura econômica privilegiam a notação "Serviços” para designar este último conjunto de atividades econômicas. Não há unanimidade na literatura econômica sobre uma classificação para os serviços; distintos critérios podem ser relevantes como: intensidade de capital, destino final ou intermediário da produção, grau de qualificação dos trabalhadores e muitos outros". MELO, Hildete Pereira de et al. O setor serviços no Brasil: uma visão global — 1985/95. Brasília: IPEA, 1998. p. 2. (Texto para Discussão n. 549). Disponível em: <http://www.ipea.gov.br/pub/td/td0549.pdf>. Acesso em: 26 jun. 2010.

"Além da emergente questão tecnológica, o setor de serviços tem uma importância fundamental para o emprego em todo o mundo. Segundo Drejer (2004), 75\% da força de trabalho dos Estados Unidos está classificada nos setores de serviços. 2 Segundo Hipp et. al. (2000), nas economias avançadas da OECD, cerca de dois terços do valor adicionado e do emprego (uma proporção crescente) se devem ao setor de serviços. No Brasil, apenas os setores contemplados pela Pesquisa Anual de Serviços (PAS) 2002, do Instituto Brasileiro de Geografia e Estatística (IBGE), compreendem 945 mil empresas, ocupando 6,85 milhões de trabalhadores. A título de comparação, a indústria compreende 135 mil empresas, e emprega 5,68 milhões de pessoas, conforme a Pesquisa Industrial Anual - Empresa, ano-base 2002”. SILVA, Alexandre Messa et al. Economia de serviços: uma revisão de literatura. Brasília: IPEA, 2006. p. 7. (Texto para Discussão n. 1173). Disponível em: <http://www.ipea.gov.br/pub/td/2006/td_1173.pdf>.

${ }^{71}$ SCALZARETTO, Reinaldo. Geografia geral: nova geopolítica. 8. ed. São Paulo: Scipione, 2001. passim.

${ }^{72}$ SILVA, Alexandre Messa et al. op. cit., p. 10.
} 
bem-estar de determinada economia. Dependendo do modo como essa razão é calculada, a produtividade pode ser um indicativo da evolução tanto da tecnologia quanto dos padrões de vida. De qualquer forma, considerando-se como insumos os fatores capital e trabalho, a origem do debate acerca da importância do setor de serviços na produtividade da economia leva em conta certas premissas. ${ }^{73}$

Manuel Castells ensina que "a teoria clássica do pós-industrialismo combinou três afirmações e previsões que devem ser diferenciadas analiticamente:

1. A fonte de produtividade e crescimento reside na geração de conhecimentos, estendidos a todas as esferas da atividade econômica mediante o processamento da informação.

2. A atividade econômica mudaria de produção de bens para prestação de serviços. O fim do emprego rural seria seguido pelo declínio irreversível do emprego industrial em benefício do emprego no setor de serviços que, em última análise, constituiria a maioria esmagadora das ofertas de emprego. Quanto mais avançada a economia, mais seu mercado de trabalho e sua produção seriam concentrados em serviços.

3. A nova economia aumentaria a importância das profissões com grande conteúdo de informação e conhecimentos em suas atividades. As profissões administrativas, especializadas e técnicas cresceriam mais rápido que qualquer outra e constituiriam o cerne da nova estrutura social". ${ }^{74}$

O setor de serviços, uma das mais importantes mudanças introduzidas no cotidiano humano no século XX, está longe de ser negligenciado, "não só por sua dimensão em termos de renda e emprego, mas também por diversos de seus segmentos estarem proporcionando insumos fundamentais ao setor industrial, como é o caso de seguros, telecomunicações, transportes e todo o setor bancário". ${ }^{75}$

No âmbito trabalhista, o setor de serviços vem apresentando "um amplo leque de estratégias diferenciadas de relações de trabalho, incluindo a flexibilização do trabalho, a criação de cooperativas, a intermediação de emprego, a informalização, de

\footnotetext{
${ }^{73}$ SILVA, Alexandre Messa et al. op. cit., p. 10.

${ }^{74}$ CASTELLS, Manuel. op. cit., p. 267.

${ }^{75}$ MELO, Hildete Pereira de et al. op. cit., p. 1.
} 
modo a caracterizar-se como uma opção de obtenção de renda, cada vez mais sem regulamentação, precarizando, assim, essas relações" ${ }^{76}$

\begin{abstract}
“As características da evolução do setor Serviços são, na verdade, a base sobre a qual se constrói a pauta a ser enfrentada pela intervenção do Estado por políticas públicas. Não é por acaso que nos países desenvolvidos as maiores preocupações da autoridade pública estão voltadas para políticas que sustentem e estimulem a eficiência dos modernos setores prestadores de serviços às empresas e para a discussão de reformas no aparato de sustentação do estado de bem-estar. $\mathrm{O}$ primeiro ponto é decisivo na definição da competitividade das empresas prestadoras de serviços, mas, sobretudo, tem relação direta com a produtividade industrial.",77
\end{abstract}

No Brasil, o Setor de Serviços responde por expressivos aumentos da geração de emprego semelhante ao ocorrido nas economias desenvolvidas. ${ }^{78}$

"O Brasil tornou-se, nas últimas décadas, uma economia na qual o setor Serviços representa quase dois terços do emprego urbano metropolitano e responde por mais da metade do PIB, numa trajetória semelhante à evolução econômica dos países desenvolvidos. ${ }^{79}$

\title{
2.3. O fenômeno da terciarização
}

Para fins analíticos, a ciência econômica estabeleceu uma divisão da atividade produtiva em três setores: o setor primário, o setor secundário e $\mathrm{o}$ setor terciário.

\footnotetext{
${ }^{76}$ RUBERTI, Kellen Cristina; GELINSKI, Carmen Rosário Ortiz Gutierrez; GUIMARÃES, Valeska Nahas. Relações de trabalho no setor de serviços no contexto da reestruturação produtiva. Disponível em: $<$ http://www.fee.tche.br/sitefee/download/jornadas/2/e8-03.pdf $>$.

${ }^{77}$ MELO, Hildete Pereira de et al. op. cit., p. 6.

${ }^{78 ،}$ O setor de serviços foi, mais uma vez, o que apresentou o maior saldo de empregos no mês passado, conforme dados do Cadastro Geral de Empregados e Desempregados (Caged), divulgado nesta sexta-feira pelo Ministério do Trabalho e Emprego. Conforme os números, houve geração de 77.201 vagas acima das demissões no mês passado. O comércio foi responsável pela criação de 60.878 postos no período e a construção civil, por 10.298. Como havia destacado o ministro Carlos Lupi, a indústria da transformação foi responsável por apenas 5.206 postos líquidos em outubro, tendo sido influenciada negativamente pela crise externa. O setor de extrativismo mineral criou 1.224 vagas no mês passado, a administração pública, 869, e os serviços industriais, 380 postos. A agricultura foi o único setor a apresentar dados negativos para o mês, com a perda de 29.913 postos. De acordo com o ministério, a redução se deve à sazonalidade do setor". SETOR de serviços puxou criação de empregos em outubro. Saldo líquido do setor foi de 77 mil vagas no mês. Veja, São Paulo, 18 nov. 2011.

${ }^{79}$ MELO, Hildete Pereira de et al. op. cit., p. 1.
} 
No setor primário são consideradas as atividades econômicas que envolvem a exploração direta dos recursos naturais: agricultura, pesca e mineração, por exemplo. O setor secundário, também designado manufatureiro, engloba as atividades pelas quais as matérias-primas obtidas no setor primário são transformadas em produtos: atividade industrial e de transformação. O setor terciário reúne, por sua vez, atividades cujos produtos não têm existência material, como é o caso do comércio e dos serviços.

Em uma economia primitiva, o setor primário abarca grande parte da mãode-obra, fenômeno atualmente encontrado em economias pouco desenvolvidas. Os países com essa característica têm seu Produto Interno Bruto sustentado amplamente por atividades agrícolas e de extrativismo natural.

A partir do momento em que a economia de uma nação alcança novos patamares de desenvolvimento, a mão-de-obra começa a ser requisitada para atuar no setor secundário em processos industriais e de transformação. Esse desenvolvimento foi o que se assistiu após as Revoluções Industriais por que passaram diversos países em diferentes períodos da história (final dos séculos XVIII e XIX e meados do século XX), fruto do acúmulo de capital proporcionado por atividades primárias e das inovações tecnológicas conquistadas às respectivas épocas.

Arion Sayão Romita ${ }^{80}$ dá notícia de dois estudos relevantes sobre esse respeito e ratificadores das idéias acima expostas. Segundo esse autor, em 1935 foi publicado o estudo The clash of progress and security pelo economista Allan B. Fisher, em que se analisava a evolução da população ativa em certo número de países. Concluiuse que no decorrer do desenvolvimento econômico a mão-de-obra se deslocara da agricultura para a indústria e, a seguir, da indústria para o comércio e os serviços. $\mathrm{O}$ segundo estudo a que Romita se refere é The conditions of economic progress, de 1940, produzido pelo economista Colin Clark, no qual se retomam as idéias de Fisher, e propõe-se a conclusão "de que o desenvolvimento econômico em todos os países é acompanhado: 1. de importante diminuição dos efetivos do setor primário, tanto em valor absoluto quanto relativo; 2. de progressão, às vezes seguida de estagnação, do setor secundário; 3. enfim, de rapidíssima expansão do setor terciário. Os fatores que determinam essa evolução são, basicamente, o progresso técnico e a evolução do

\footnotetext{
${ }^{80}$ ROMITA, Arion Sayão. A terciarização e o direito do trabalho. Revista LTr, São Paulo, v.56, n. 3, p. 273279, mar. 1992.
} 
consumo". Clark ainda define o setor terciário como aquele em que se encontram todas as atividades que não têm por objeto elaborar uma produção física.

Esse estudo de 1940 descreve o desenrolar de acontecimentos que se seguiram à Segunda Guerra Mundial. As economias desenvolvidas passaram por uma afirmação do Setor Secundário, com base nas práticas Fordistas de organização empresarial e acumulação de capitais. Foram nessas décadas, posteriores a 1945, que a atividade industrial confirmou as bases do Direito do Trabalho como sistema protetor do trabalhador empregado por meio de uma relação de subordinação ao seu empregador. $\mathrm{O}$ trabalho em um sistema fordista contava com uma realidade fática passível de ser controlada por normas rígidas sobre local e duração do trabalho, remuneração, pessoalidade e habitualidade da prestação do serviço, por exemplo.

Em estudo sobre a crise do direito laboral, Maria do Rosario Palma Ramalho ${ }^{81}$ estabelece essa conexão entre a relação de trabalho típica e a estrutura fordista de organização empresarial, propondo que a subordinação típica está intimamente ligada à grande unidade industrial em que são facilmente determináveis os aspectos que regem a relação dos trabalhadores com seu empregador e que dão suporte ou são objeto das normas trabalhistas.

Entretanto, nos anos 1970, reuniram-se fatores que apontavam para a fragilização do sistema fordista: após os choques do petróleo (1973 e 1979) e com as inovações tecnológicas dessa época, sobretudo nos setores de comunicação e informação principalmente nos anos 1980, o sistema produtivo e as relações de trabalho foram postos em xeque, pois a estrutura produtiva fordista não era mais capaz de aumentar seus ganhos ou, ao menos, manter seus lucros.

Nesse bojo, passou-se a assistir a um crescimento intenso do setor terciário da economia, nos moldes do modelo proposto por Colin Clark, citado por Romita ${ }^{82}$. Na busca por minimização de custos e maximização de lucros, o setor secundário passou a recorrer a prestadores de serviços que fossem capazes de otimizar seus processos produtivos ou oferecer serviços que substituíssem atividades de sua cadeia produtiva a um custo mais baixo do que o de contratar mão-de-obra própria. Dessa forma, começou a

\footnotetext{
${ }^{81}$ RAMALHO, Maria do Rosario Palma. Ainda a crise do direito laboral: a erosão da relação de trabalho "típica" e o futuro do Direito do Trabalho. In: MOREIRA, Antonio (Coord.) III Congresso Nacional de Direito do Trabalho - Memórias. LISBOA: Almedina, 2000. p. 257.

${ }^{82}$ ROMITA, Arion Sayão. A terciarização e o direito do trabalho, cit., p. 273-279.
} 
crescer a demanda por profissionais de consultoria para aperfeiçoar o desempenho da atividade industrial (tecnologia da informação, e.g.) e por empresas que se encarregassem de organizar trabalhadores para exercer funções dentro da indústria, sem serem empregados desta (prestadores de serviço, terceirização, e.g.).

\subsubsection{As críticas ao processo de terciarização da economia}

A principal crítica ao setor terciário é a de que não há produção material de riqueza. Conforme proposto por Clark citado por Romita, as atividades do setor terciário, em oposição à atividade industrial, não têm por objetivo elaborar uma produção física. $\mathrm{O}$ setor terciário tem por característica própria a produção de bens econômicos imateriais, dirigidos à satisfação de alguma necessidade ou carência por meio da realização de um serviço em favor de seu tomador.

Essa tese vem desde Adam Smith como aponta o economista francês Jean Gaudrey $^{83}$, ao afirmar que as atuais críticas sobre o papel econômico dos serviços já haviam sido propostas nas primeiras grandes obras de economia política.

Esse economista francês explica que em "A Riqueza das Nações”, Adam Smith estabeleceu a distinção entre o trabalho produtivo, que agrega valor à matériaprima, e as atividades de serviço, que são improdutivas, pois o trabalho empregado não dá origem a um produto material. Entretanto, Gaudrey afirma que a idéia expressa por Smith dizia respeito aos serviços domésticos, estatais, militares e artísticos, não se comparando às sofisticadas atividades de serviço que foram desenvolvidas a partir dos anos 1980. A despeito disso Gaudrey relata, em seguida, a afirmação de Dominique Strauss-Khan ${ }^{84}$ pela qual o crescimento do setor terciário se daria à reboque da atividade industrial, pois estaria no setor secundário a força de demanda por serviços e somente haveria "verdadeiros empregos" na indústria.

\footnotetext{
${ }^{83}$ GAUDREY, Jean. Un demi-siècle de montée des services: la révolution permanente. Le Mouvement Social, n. 211, p. 21-36, 2005. Disponível em: <<http://www.cairn.info/article.php?ID_REVUE=LMS\&ID_NUMPUBLIE=LMS_211\&ID_ARTICLE= LMS_211_0021>. Acesso em: 03 abr. 2009.

${ }^{84}$ Ministro da Economia da França à época desse comentário e antigo Diretor-Gerente do Fundo Monetário Internacional - FMI.
} 
O sociólogo português João Ferrão apresenta uma posição mais acurada a respeito. Segundo Ferrão, o processo de terciarização por que a economia vem passando desde meados da década de 1970, pode ser observado sob duas óticas distintas. De um lado está a posição que vê a Terciarização simplesmente como a expansão do setor econômico em que estão as atividades produtoras de bens imateriais e intangíveis. Por outro lado, pode-se entender que esse processo diz respeito a um movimento maior de reestruturação dos sistemas produtivos "verificando-se um processo de transformação intersectorial baseado na crescente integração das actividades secundárias $(\mathrm{e}$, em menor escala, agrícolas) e terciárias". ${ }^{85}$

Ferrão propõe que não se trata de um declínio do setor industrial em favor do terciário, mas que o processo de terciarização da economia pressupõe a modificação nas relações estabelecidas entre a indústria e os serviços, uma vez que "nem o sector industrial desapareceu, nem os serviços substituíram a produção de bens". Esse autor endossa a afirmação de que o acúmulo de capital tanto na indústria, como nas próprias unidades familiares de consumo, fizeram crescer a demanda por serviços cada vez mais sofisticados. Esse acúmulo de capital, aliado à necessidade premente de reestruturação interna do setor industrial, preparou o caminho para o grande crescimento do setor terciário. Por fim, Ferrão aponta dois fatores cruciais para o desenvolvimento do setor terciário a partir dos anos 1980: reestruturações organizacionais e tecnológicas, e transformações das condições e modos de consumo.

\subsubsection{O fenômeno da terciarização na prática: Portugal}

Neste panorama, propõe-se debruçar-se brevemente sobre a experiência portuguesa dadas suas características bem definidas no processo de terciarização da economia.

\footnotetext{
${ }^{85}$ FERRÃO, João. Entender o actual processo de «terciarização»: das teses às dúvidas. Análise Social, v. 24, n. 101/102, p. 703-717, $1988 . \quad$ Disponível em $<$ http://analisesocial.ics.ul.pt/documentos/1223031386S1wGH8bg2Bw91DJ6.pdf>. Acesso em: 25 mar. 2009.
} 
Portugal se enquadra dentre os países de industrialização tardia, como relata Aida Ferreira ${ }^{86}$. Ela sustenta que o processo de terciarização em Portugal ocorreu não só pela demanda produzida pelo setor secundário por serviços, mas, inclusive, pela incapacidade de absorver mão-de-obra apresentada pela incipiente atividade industrial portuguesa.

A título de exemplo sobre a situação européia nesse assunto, depreende-se dos dados expostos na tabela abaixo, que o crescimento da criação líquida de emprego na Europa a partir dos anos 1980 nos setores de atividade terciários foi muito maior que o verificado nos setores ligados à atividade industrial, por exemplo: o indicador sobre a indústria de borracha e plástico apresenta variação de $24,9 \%$, ao passo que os dois itens sobre prestação de serviços propriamente dita, variaram mais de $60 \%$ no período considerado.

\begin{tabular}{|l|l|}
\hline \multicolumn{2}{|l|}{ Tabela I } \\
\hline \multicolumn{2}{|l|}{ Criação líquida de emprego (1980-1995) } \\
\hline Sectores & variação (\%) \\
\hline Serviços colectivos, sociais e pessoais & $65,0 \%$ \\
\hline Serviços financeiros e serviços às empresas & $62,5 \%$ \\
\hline Comércio, hotelaria, restauração & $18,4 \%$ \\
\hline Sectores de tecnologia de ponta & $3,3 \%$ \\
\hline Borracha e plástico & $24,9 \%$ \\
\hline Farmacêutica & $14,6 \%$ \\
\hline Computadores e informática & $8,6 \%$ \\
\hline Transportes e logística & $7,4 \%$ \\
\hline Papel e impressão & $7,3 \%$ \\
\hline
\end{tabular}

\footnotetext{
${ }^{86}$ FERREIRA, Aida. A terciarização no feminino. Serviço Social no Feminino - Jornadas Internacionais. Centro Português de Investigação em História e Trabalho Social - CPIHTS, n. 51/58, jun. 1995. Disponível em <http://www.cpihts.com/PDF/Aida\%20 Ferreira.pdf>. Acesso em: 25 mar. 2009.

${ }^{87}$ OCDE: Second European Report on Scientific and Technological Indicators. (1997: 34) apud MONIZ, António Brandão. Estratégias de construção da Sociedade da Informação. Munich Personal RePEc Archive. Disponível em <http://mpra.ub.uni-muenchen.de/6633/1/cap_2_EUPT_repec.pdf>. Acesso em: 21 mar. 2009.
} 


\begin{tabular}{|l|l|}
\hline Componentes electrónicos & $4,6 \%$ \\
\hline Química & $3,9 \%$ \\
\hline Automóvel & $0,3 \%$ \\
\hline Tecnologia intermédia & $-8,2 \%$ \\
\hline Sectores de baixa tecnologia & $-10,9 \%$ \\
\hline
\end{tabular}

António Barreto ${ }^{88}$ informa que a distribuição da força de trabalho entre os setores de atividade na economia de Portugal se alterou significativamente desde 1960 até 1998 de acordo com os seguintes dados: o setor primário diminui drasticamente de 43,6\% para $7 \%$; o setor secundário variou positivamente de $28,9 \%$ para $37,9 \%$ e o setor terciário cresceu quase ao dobro, de $27,5 \%$ para $51,3 \%$.

Dados mais recentes são apresentados pelo Instituto Nacional de Estatística de Portugal - INE, dando conta de que em 2005 o setor terciário continuava a aumentar, chegando a abranger $57,6 \%$ do total de empregados do país ${ }^{89}$. Por fim, ainda segundo estudos do INE em 2007, "em termos de sectores de actividade (numa lógica tradicional de sector Primário, Secundário e Terciário), Portugal é claramente dominado pelo sector Terciário (dos Serviços), que representa $58,7 \%$ do $\mathrm{VAB}^{90}$ e $62,3 \%$ do emprego total do sector empresarial". ${ }^{91}$

Esses indicadores demonstram inegavelmente a força do fenômeno de terciarização tanto em Portugal como no contexto geopolítico europeu em que está inserido. Para o Direito do Trabalho, importa que 62,3\% dos empregos estão

${ }^{88}$ BARRETO, António (org.). A situação Social em Portugal, 1960-1992. v. 2. LISBOA: ICS, 2000. apud CRUZ, Sofia Alexandra. Uma cartografia do trabalho precário, as mulheres (des) alinhadas na precariedade. Porto: Sociologia, n. 12, p. 164, 2002. Disponível em: <http://ler.letras.up.pt/uploads/ficheiros/1493.pdf>. Acesso em: 03 abr. 2009.

${ }^{89}$ INSTITUTO NACIONAL DE ESTATÍSTICA - PORTUGAL. Indicadores sociais - edição de 2005, dez. 2006. p. 5. Disponível em: <http://www.ine.pt>. Acesso em: 02 abr. 2009.

${ }^{90} \mathrm{VAB}$ : "valor acrescentado bruto - valor bruto da produção deduzido do custo das matérias-primas e de outros consumos no processo produtivo", segundo INSTITUTO NACIONAL DE ESTATÍSTICA PORTUGAL. Disponível em: $<$ http://metaweb.ine.pt/sim/conceitos/Detalhe.aspx?cnc_cod=4684\&cnc_ini=22-03-2004\%200:00:00>. Acesso em: 02 abr. 2009.

${ }^{91}$ Id. Ibid., p. 3. 
concentrados no Setor Terciário e são as relações estabelecidas neste âmbito que devem chamar a atenção dos juslaboralistas.

Maria do Rosário Palma Ramalho analisa as consequiências desse fenômeno para as relações entre a empresa e seus trabalhadores. Essa professora aponta que o desenvolvimento do setor de serviços "acompanhado do desenvolvimento tecnológico e da mundialização da economia, propiciou o surgimento, ao lado das grandes empresas-ilha, de empresas muito mais pequenas, altamente especializadas, competindo internacionalmente e com uma estrutura interna que torna desnecessária certas tarefas e viabiliza amplas reduções de pessoal, em favor do recurso a serviços externos, menos onerosos para os empresários". ${ }^{92}$ Nesse ponto surge a questão crucial para a Terciarização que é a dificuldade que as empresas têm em gerenciar seu quadro de trabalhadores, tendo em vista o "princípio de segurança no emprego" consagrado no artigo $53^{\circ}$ da Constituição da República Portuguesa (CRP).

No capítulo III da CRP, sob o título dos Direitos, liberdades e garantias dos trabalhadores, o artigo $53^{\circ}$ (Segurança no emprego) dispõe o seguinte:

"É garantida aos trabalhadores a segurança no emprego, sendo proibidos os despedimentos sem justa causa ou por motivos políticos ou ideológicos."

O Código de Trabalho promulgado em 2009 introduz esse preceito fundamental na legislação ordinária, dispondo em seu capítulo VII da Cessação de contrato de trabalho, artigo 338. (Proibição de despedimento sem justa causa):

"É proibido o despedimento sem justa causa ou por motivos políticos ou ideológicos."

Tendo em vista a proibição legal de dispensa sem justa causa, os empregadores portugueses têm que encontrar meios de gerenciar sua estrutura empresarial sem poder despedir os trabalhadores contratados. A necessidade de reestruturar o quadro funcional das empresas em velocidade compatível com as mudanças

\footnotetext{
${ }^{92}$ RAMALHO, Maria do Rosario Palma. Insegurança ou diminuição do emprego? A rigidez do sistema jurídico português em matéria de cessação do contrato de trabalho e de trabalho atípico. Revista LTr, São Paulo, v. 64, n. 8, p. 1019, ago. 2000.
} 
impostas por uma realidade econômica mais dinâmica que a do período fordista, faz com que as empresas recorram a formas alternativas de gerenciar os recursos humanos lançando mão de mecanismos previstos em lei que lhes ofereçam a mobilidade de pessoal necessária à otimização funcional da atividade econômica que exercem.

É nesse contexto que são introduzidas práticas de "externalização": instrumentos que permitem a mobilidade de trabalhadores contratados sem que os trabalhadores sejam dispensados. Nas palavras de Aida Ferreira"3 "a reorganização do sector secundário conduziu à ampliação do sector terciário através do fenómeno da ‘externalização' ou 'terceirização' - tarefas realizadas por terceiros fora da empresa e que não correspondem à sua vocação principal”.

\subsubsection{Breve escorso sobre externalização}

O sistema trabalhista português conta com o princípio da segurança no emprego, insculpido no artigo 53 da Constituição da República de Portugal. Como visto acima, não é possível dispensar um trabalhador sem justa causa o que limita a liberdade dos empresários em promover ajustes em sua estrutura de recursos humanos.

Nesse cenário, desenvolveram-se práticas que passaram a ser denominadas

de "externalização". Tratam-se de mecanismos que permitem ao empregador recorrer a trabalho externo à sua estrutura empresarial sem que precise contratar trabalhadores. Podem ser consideradas como formas de externalização: a cedência ocasional de trabalhadores, os trabalhadores temporários cedidos por Empresas de Trabalho Temporário - ETT, os trabalhadores contratados por uma pluralidade de empregadores e a celebração de contrato de empreitada com empresa prestadora de serviço.

O contrato de empreitada é utilizado por empresas que tenham a intenção de recorrer a trabalho externo à sua estrutura para realizarem determinadas atividades diversas de seu núcleo essencial por meio de empresas prestadoras de serviço. Nesse caso, celebra-se um contrato puramente civilista entre empresas, permitindo que a empresa contratante tenha um quadro de trabalhadores mais enxuto, centrado nas

${ }^{93}$ FERREIRA, Aida. op. cit. 
atividades essenciais à sua atividade produtiva e que as atividades ditas não-essenciais sejam realizadas por trabalhadores de empresas especializadas.

$\mathrm{Na}$ cedência ocasional uma empresa cede um tabalhador seu a outra empresa que se utilizará de seus serviços por período de tempo determinado ao fim do qual esse trabalhador retornará à empresa que o cedera. Nessa hipótese, permite-se a mobilidade do trabalhador sem despedimento: ele trabalha para outra empresa e não perde seu emprego na empresa de origem. O trabalhador permanece no mercado de trabalho, mas pode prestar seus serviços em empresas diversas da que o contratou originalmente.

As Empresas de Trabalho Temporário são entidades constituídas com o objetivo específico de contratar trabalhadores, oferecer-lhes formação e cedê-los para trabalhar em empresas que necessitem dos seus serviços. $O$ trabalhador tem vínculo com a ETT que o cede para exercer seu trabalho em outras empresas. Trata-se, mais uma vez, de hipótese em que o trabalhador tem mobilidade para trabalhar em outras empresas sem necessidade de despedimento.

Por fim, há o caso peculiar da contratação por uma pluralidade de empregadores. Nesse caso, o trabalhador é contratado por um grupo de empresas (que não necessariamente precisam pertencer a um mesmo grupo empresarial como no caso do parágrafo $2^{\circ}$. do artigo $2^{\circ}$. da CLT, pois as empresas podem reunir-se ad hoc para realizar esse tipo de contratação) e torna-se lícito o seu deslocamento entre essas empresas para exercer suas atividades. Não haverá necessidade de que seja despedido de uma empresa para vir a integrar a estrutura da outra empresa em que prestará seus serviços. Nesse caso entende-se que o trabalhador não fica adstrito ao quadro funcional de uma só empresa do grupo. Eventualmente, qualquer empresa desse grupo pode vir a utilizar-se dos seus serviços e, quando o fizer, estará recorrendo a trabalho externo à sua estrutura, pois, até aquele momento, esse trabalhador estava exercendo suas atividades dentro da estrutura de outra instituição componente do grupo.

O aspecto que identifica os institutos apontados como formas de externalização é o fato de que, em qualquer dos casos, a empresa que se utilizar desses mecanismos estará recorrendo a trabalhadores externos à sua estrutura empresarial. Com essas hipóteses de externalização, o empresário português tem ao seu dispor maneiras de lidar com o crescente dinamismo do ambiente de negócios e a necessidade de gerenciar 
sua necessidade por mão-de-obra, minimizando as restrições impostas pelo princípio de segurança no emprego. Pode-se, por exemplo, atender a um aumento temporário de serviços sem que a empresa tenha que contratar e, posteriormente, despedir a mão-de-obra necessária.

Como todos os demais países industrializados, Portugal foi afetado pelos efeitos da crise do sistema fordista e das situações que se apresentaram em seguida. A economia portuguesa passou por um processo de terciarização como pôde-se perceber pelos dados apresentados acima e o Direito do Trabalho sofreu mudanças para regular situações fáticas que se mostravam relevantes e introduzir novas normas no ordenamento que servissem a regulamentar apropriadamente aspectos inéditos das relações trabalhistas.

Nesse ambiente, o grande desafio para os legisladores foi o de criar mecanismos que permitissem aos empresários portugueses gerenciar apropriadamente seu quadro de funcionários, mantendo o princípio constitucional de segurança no emprego intocado. Assim, ao longo das últimas décadas, foram realizadas reformas e promulgadas novas leis que sincronizaram o Direito do Trabalho português à necessidade inescapável de modernização da estrutura empresarial.

Dessa forma aperfeiçoou-se a maneira de ceder trabalhadores sem dispensá-los inclusive regulamentando fortemente a atividade de empresas especializadas nisso como as Empresas de Trabalho Temporário; entendeu-se lícita a possibilidade de externalizar parte não-essencial da atividade produtiva por meio de contratos de empreitada com empresas especializadas em prestação de serviços e, por fim, criaram-se regras para a possibilidade de um trabalhador ser contratado por um grupo de empresas e poder atuar em todas as instituições que o compõem sem prejuízos para suas condições de trabalho.

A análise da experiência portuguesa perante a realidade pós-fordista e o inevitável processo de terciarização da economia, pode levar ao entendimento de que foi possível atender às demandas do empresariado, sem abrir mão da proibição de dispensa sem justa causa. Em um sistema que concede aos trabalhadores a maior das proteções por meio do princípio constitucional de segurança no emprego, foi possível mantê-lo e dar mobilidade aos quadros funcionais, ferramenta indispensável ao gerenciamento empresarial. 


\subsection{A atuação sindical em tempos de globalização}

Em virtude da globalização e de diversos movimentos de integração econômica tanto bilaterais quanto multilaterais, as fronteiras nacionais tornaram-se mais fluidas. Nessa esteira o mundo do trabalho passou a sofrer pressões externas, pois as grandes empresas passaram a contar com a possibilidade de deslocar parte de sua estrutura para o exterior.

Atualmente, p. ex., empresas industriais podem produzir seus produtos em países como China, Indonésia, Tunísia etc, e grandes prestadoras de serviço podem estabelecer seu serviço de telemarketing em países como a Índia (prática comum em países de língua inglesa, favorecidos pela colonização britânica daquele país).

O traço comum entre os países aqui referidos é o baixo custo da mão-deobra, fruto da inexistência de princípios protetivos do trabalho. Para os países de onde as empresas retiram parte de sua estrutura para estabelecê-la no exterior, resta conseguir lidar com a diminuição de postos de emprego. Tal situação, na qual um país oferece mão-de-obra mais barata em virtude da ausência de proteção aos seus trabalhadores pode ser comparado a práticas de dumping comercial $^{94}$, algo que pode ser denominado como dumping social: o preço da mão-de-obra praticado é inferior ao de outros países, pois as condições de vida, trabalho e, por fim, de dignidade humana são inferiores; os países que protegem esses aspectos da vida humana não conseguem oferecer mão-de-obra mais barata, porque não permitem que seus trabalhadores sejam submetidos às condições de vida admitidas naqueles países.

Além da concorrência de países cuja mão-de-obra tem preço mais baixo, os postos de emprego são pressionados por avanços tecnológicos. Assim como a introdução da máquina a vapor no século XIX, a incorporação de tecnologias de ponta no processo produtivo tem contribuído para a redução do número de trabalhadores empregados. Para Patrícia Bertolin:

\footnotetext{
${ }^{94}$ No artigo VI do General Agreement on Tariffs and Trade, 1994 (GATT) dumping é definido como sendo a fixação do preço de exportação, para um determinado bem e país, a um nível inferior ao seu valor normal. WTO. Disponível em: <http://www.wto.org/english/docs_e/legal_e/06gatt_e.htm>.
} 
"Os novos processos produtivos resultantes da incorporação de tecnologias de ponta têm sido responsáveis por notável redução do número de empregos, fenômeno a que os especialistas costumam chamar de desemprego tecnológico, que se agrava com a utilização do trabalho temporário e da terceirização, que constituem a maior parte da força de trabalho contingencial. Sua própria existência age como redutor dos salários dos trabalhadores fixos". ${ }^{95}$

\title{
Para Manuel Castells,
}

\begin{abstract}
"O processo de trabalho situa-se no cerne da estrutura social. A transformação tecnológica e administrativa do trabalho e das relações produtivas dentro e em torno da empresa emergente em rede é o principal instrumento por meio do qual o paradigma informacional e o processo de globalização afetam a sociedade em geral." ${ }^{, 96}$
\end{abstract}

No Brasil, embora a abertura econômica tenha visto seu início durante o governo Sarney (1988), o grande impulso aconteceu de 1990 em diante, a partir do governo Collor.

"No governo Sarney, em 1988, a abertura econômica que teve início e ganhou grande impulso em 1990 com o governo Collor, é vista como marco da transição para um contexto de organização industrial marcado pelos parâmetros da competitividade e liberalização do comércio." ${ }^{.97}$

Em 1990, o então presidente Fernando Collor, adotou medidas de favorecimento às importações e deu início ao Programa Nacional de Desestatização. ${ }^{98}$

A abertura da economia brasileira, fez com que as empresas, a fim de enfrentar a concorrência internacional e ganhar vantagem competitiva, investissem na modernização do processo produtivo, em mudanças tecnológicas e no aperfeiçoamento de sua gestão. ${ }^{99}$

\footnotetext{
${ }^{95}$ BERTOLIN, Patrícia Tuma Martins. op. cit.

${ }^{96}$ CASTELLS, Manuel. op. cit., p. 265.

${ }^{97}$ FONSECA, Maria Leila Rezende do Vale; ALENCAR, Edgard; BARBOSA, J. Humberto. Percepçao da força de trabalho no processo de mudança tecnológica e organizacional: um estudo de caso. OGT 01-04. Disponível em: <http://www.ichs.ufop.br/conifes/anais/OGT/ogt0104.htm>. Acesso em: 17 nov. 2010.

${ }^{98}{ }^{2}$ ei $\mathrm{n}^{\circ}$ 8.031, de 12 de abril de 1990, revogada, no Governo FHC, pela Lei n. 9.491, de 9 de setembro de 1997 alterando procedimentos relativos ao Programa Nacional de Desestatização.

99،"Para enfrentar a concorrência e ganhar vantagem competitiva, ficaram evidenciadas as mudanças ocorridas tanto do processo produtivo como o administrativo, segundo o setor que cada empresa atua.
} 
Há entendimento no sentido de que a modernização dos processos de produção das empresas elevou "as exigências na contratação de novos trabalhadores e sinaliza (sic) a direção por onde passarão as demissões". ${ }^{100}$

Os reflexos dessa modernização na produção atingiram. por fim, a representatividade dos sindicatos, diminuindo-a:

No Brasil, a luta operária e popular passou, ao longo da década de dois mil, por um período que, em contraste com as décadas precedentes, poderíamos denominar um período de acomodação política. A luta reivindicativa não refluiu, mas a agitação e a luta contra o modelo capitalista neoliberal perderam terreno.

A década dos noventa foi uma década de refluxo. Diversos fatores econômicos e políticos, nacionais e internacionais - concorreram para tal. Logo no início dos anos noventa, a posse do governo neoliberal de Fernando Collor, que derrotara a candidatura Lula na eleição presidencial de dezembro de 1989, a recessão da economia capitalista e a política econômica do novo governo acuaram politicamente $o$ movimento sindical e popular e derrubaram a produção o emprego de maneira abrupta. A difusão dos processos de reestruturação produtiva e, no plano internacional, a desintegração da antiga URSS, que provocou uma crise ideológica no movimento operário e socialista, somaram-se àqueles fatores para configurar uma conjuntura que abateu o movimento operário e popular brasileiro e o levou ao refluxo. Quando, doze anos mais tarde, na eleição presidencial de 2002, a "candidatura Lula" foi vitoriosa, o programa de campanha e do candidato já era outro. A candidatura Lula e o PT tinham abandonado o programa de reformas que defenderam nos anos oitenta e passaram a conciliar com o modelo neoliberal. ${ }^{101}$

No estudo feito por Andréia Galvão, Boito Jr., Claudinei Colleti e Patrícia

Trópia, no ano de 2001, o "movimento sindical empreendeu algumas lutas importantes...,

Uma das estratégias adotadas pelas empresas foi a ampliação e diversificação da linha de produtos. Outra mudança foi à ampliação da fatia no mercado nacional, investimentos estratégicos e a reestruturação administrativa para acompanhar o novo padrão de produção. E consequentemente, a desativação do laboratório de P \& D para reduzir custos, evidenciando a prática de benchmarking e a realização de convênios com centros de pesquisas (EMBRAPA) e universidades, para suporte na implantação de novos métodos e técnicas de gestão da produção". FONSECA, Maria Leila Rezende do Vale; ALENCAR, Edgard; BARBOSA, J. Humberto. op. cit.

${ }^{100}$ FONSECA, Maria Leila Rezende do Vale; ALENCAR, Edgard; BARBOSA, J. Humberto. op. cit.

${ }^{101}$ BOITO JR., Armando; MARCELINO Paula. Brasil: o movimento sindical e popular na década de 2000. Observatorio Social de América Latina (OSAL), Buenos Aires, ene. 2002. Disponível em: $<$ http://pt.scribd.com/doc/26232285/Brasil-o-movimento-sindical-e-popular-na-decada-de-2000>. Acesso em: 10 out. 2011. 
mas não obteve vitórias expressivas e permaneceu dividido frente à política
neoliberal". ${ }^{102}$

Um exemplo do conflito entre as centrais sindicais Força Sindical - FS e CUT - Central Única dos Trabalhadores, reside na adoção de políticas diferentes na condução das lutas e na posição política:

\begin{abstract}
"Houve também algumas lutas e ações importantes organizadas diretamente pela cúpula do movimento sindical, especialmente pelas lideranças congregadas na Central Única dos Trabalhadores (CUT) e na Força Sindical (FS), as mais representativas entre as oito centrais sindicais brasileiras. CUT e FS caracterizam-se por assumir posições opostas no plano político e nas lutas conduzidas: enquanto a prática da CUT se destaca pela resistência ao modelo neoliberal, a marca da FS é a adesão e o apoio ao neoliberalismo. Em 2001, a atuação dessas centrais foi bastante diferenciada e, em vários momentos, conflitante."
\end{abstract}

102“No que se refere à ação sindical nas bases, os sindicatos ligados à Central Única dos Trabalhadores (CUT), que é a maior central brasileira e a mais mobilizada contra a política neoliberal, promoveram, no segundo semestre de 2001, pelo menos duas greves significativas: a greve dos servidores públicos federais e a greve dos metalúrgicos da Volkswagen". GALVÃO, Andréia; BOITO JR., Armando; COLLETI, Claudinei; TRÓPIA, Patrícia. Lutas sociais no Brasil em 2001. p. 62. Observatorio Social de América Latina (OSAL), Buenos Aires, p. 62, ene. 2002. Disponível em: <http://168.96.200.17/ar/libros/osal/osal6/sur.pdf>. Acesso em: 06 mar. 2011.

${ }^{103}$ GALVÃO, Andréia; BOITO JR., Armando; COLLETI, Claudinei; TRÓPIA, Patrícia. 0p. cit., p. 62. Como exemplo da adoção de políticas diferentes, os autores discorrem sobre a crise na energia, ocorrida em 2001: "Um segundo eixo de atuação do movimento e das centrais sindicais referiu-se à crise de energia. Atribuída pela CUT ao contínuo corte de investimentos e à falta de políticas de longo prazo nas diferentes áreas de atuação do governo federal, gerou reações diversas nas centrais. A CUT responsabilizou o governo pelo abandono das funções estratégicas de planejamento do Estado e pela adoção de um modelo de privatização que, além de transferir o controle do sistema de geração e distribuição de energia a operadoras privadas, não exerceu de modo satisfatório as funções públicas de regulação e fiscalização do novo sistema. Para enfrentar as conseqüências decorrentes da desaceleração da economia e, dentre essas, principalmente o aumento do desemprego, a CUT elaborou um projeto de emenda popular à Constituição Federal garantindo a estabilidade no emprego enquanto durasse o racionamento. Além disso, propôs uma série de medidas que revelam uma contraposição a determinados aspectos da política neoliberal, como a suspensão e a revisão das privatizações no setor elétrico, a proibição das horas extras e do funcionamento do comércio aos domingos. A reação da CUT adquiriu visibilidade na Marcha Contra o Apagão e a Corrupção, ocorrida em 27 de junho para protestar contra o racionamento de energia e a escalada de corrupção, sob a bandeira do "Fora FHC e o FMI"

Já a FS reagiu de forma contraditória à crise energética. Se, de um lado, aprovou as medidas paliativas adotadas pelo governo, de outro propôs a suspensão temporária das privatizações do setor elétrico projetadas para o segundo semestre de 2001 e início de 2002 -privatização que fora, até então, sistematicamente defendida pela central. No geral, a FS aceitou o diagnóstico apresentado pelo governo para explicar a crise de energia, atribuída por FHC à "falta de chuvas" e ao conseqüente baixo nível da água nas represas das usinas hidrelétricas. Entre as propostas divulgadas pela FS, destacaram-se a redução da jornada de trabalho para 40 horas semanais, a diminuição de impostos para a indústria metalúrgica e para as produtoras de geradores, o abrandamento do racionamento de energia para o setor industrial e, por fim, o fechamento do comércio aos domingos. Na prática, a FS mobilizou-se apenas para obter o abrandamento do racionamento para alguns ramos industriais. Id. Ibid., p. 63. 
Além das diferenças ideológicas dos sindicatos em geral, o fluxo industrial que movimenta a atividade econômica e o novo modo de produtividade das empresas tem contribuído para o declínio da entidade sindical. O reflexo desta mudança, no cenário da economia global, indica a redução das receitas dos sindicatos e a perda do poder de mobilização no enfrentamento de negociações.

Os dias, tempos atrás, já foram visivelmente mais confortáveis para os sindicatos. Atualmente, com o desenvolvimento tecnológico e com as pressões de concorrência com mercados de trabalho de outros países, as relações de trabalho estão sendo redefinidas e, no direito sindical, "percebe-se um gradual enfraquecimento das entidades sindicais. A partir da adoção do pacto proposto pelo Estado do bem-estar, para evitar o conflito de classes, houve uma efetiva perda de importância das entidades sindicais, até mesmo para o próprio operariado". 104

Na legislação brasileira, já existem recursos que permitem alterações negociadas nas condições de trabalho como, p. ex., por meio de acordos coletivos ${ }^{105}$, podendo-se apontar como um dos objetivos da utilização dessa ferramenta a promoção de maior dinamismo na resolução de questões conflituosas no Direito do Trabalho. Esse aspecto da utilização dos acordos coletivos pode ser entendido como uma ferramenta de flexibilização do Direito do Trabalho.

Para Sérgio Pinto Martins, “As causas da flexibilização compreendem vários fatores: a) desenvolvimento econômico; b) globalização; c) crises econômicas; d) mudanças tecnológicas; e) encargos sociais; f) aumento do desemprego; g) aspectos culturais; h) economia informal; i) aspectos sociológicos". 106

"Os sindicatos brasileiros mudaram sua atuação em diversos sentidos.
No que se refere às negociações coletivas, principalmente na indústria,
passaram a negociar mais descentralizadamente. No nível institucional,
ocuparam uma série de espaços abertos pelo recuo da ação do Estado
em termos de sua regulação na economia. Do ponto de vista de seus

${ }^{104}$ CORREIA, Marcus Orione Gonçalves. O contrato individual do trabalho no contexto neoliberal: uma análise crítica. Revista LTr, São Paulo, ano 67, n. 4, p. 424, maio 2003.

${ }^{105}$ Conforme o art. $7^{\circ}$, inc. XXVI, da Constituição Federal: "reconhecimento das convenções e acordos coletivos de trabalho", podendo, inclusive haver redução salarial mediante a celebração de acordo coletivo de trabalho", conforme o inciso VI do mesmo artigo. Além disso, os artigos XIII e XIV dispõem sobre a jornada de trabalho no mesmo sentido: "XIII - duração do trabalho normal não superior a oito horas diárias e quarenta e quatro semanais, facultada a compensação de horários e a redução da jornada, mediante acordo ou convenção coletiva de trabalho"; "XIV - jornada de seis horas para o trabalho realizado em turnos ininterruptos de revezamento, salvo negociação coletiva".

${ }^{106}$ MARTINS, Sergio Pinto. Flexibilização das condições de trabalho. São Paulo: Atlas, 2009. p. 35. 
assuntos, também foram obrigados a lidar com novos temas como reestruturação produtiva, emprego, flexibilização, integração econômica, formação profissional etc. Da mesma maneira, do lado patronal, diante da multiplicação de espaços de negociação coletiva, muito provavelmente deve ter aumentado a demanda por pessoal especializado em negociações junto aos trabalhadores". ${ }^{107}$

Como apontado no início do presente estudo, a trajetória dos sindicatos no Brasil foi assinalada por um forte vínculo com o Estado e a sua atuação, geralmente restrita ao território nacional. Todavia, em decorrência da globalização das relações de trabalho, os sindicatos são compelidos a ultrapassar os limites territoriais a fim de posicionar-se no cenário da internacionalização para criar novas formas de ação em defesa do emprego. Do mesmo modo que o Direito do Trabalho como um todo, os sindicatos são instados a encontrar novas formas de atuação frente às pressões por mudanças impostas pelos efeitos da globalização.

\footnotetext{
${ }^{107}$ AMORIM, Wilson Aparecido Costa de. Negociações coletivas no Brasil: uma análise do período 19902004. 


\title{
3. SINDICATO E GARANTIA DE EMPREGO
}

\subsection{A regulação do mercado de trabalho e o papel dos sindicatos}

\author{
Competitividade para Manuel Castells é um "conceito de difícil \\ compreensão" e o autor de a Sociedade em Rede apresenta uma definição "razoável" \\ fornecida por Stephen Cohen:
}

\begin{abstract}
"a competitividade tem diferentes sentidos para as empresas e para a economia nacional. A competitividade de uma nação é o grau em que ela pode, sob condições de mercados livres e justas, produzir bens e serviços que atendam às exigências dos mercados internacionais e, ao mesmo tempo, aumentem a renda real de seus cidadãos. A competitividade na esfera nacional é baseada em um desempenho superior de produtividade pela economia e na capacidade da economia transferir a produção para atividades de alta produtividade que, por sua vez, podem gerar altos níveis de salários reais"
\end{abstract}

O final do século XX, no Brasil, foi assinalado pela ação do Estado na implementação de parâmetros da política neoliberal ${ }^{109}$ na condução da economia, objetivando a inserção do país no cenário de competitividade econômica internacional.

As medidas para a aplicação de políticas neoliberais começaram a ser tomadas a partir da década de 1980, tendo como um de seus objetivos "o combate ao

\footnotetext{
${ }^{108}$ CASTELLS, Manuel. op. cit., p. 139.

109 “Neoliberalismo é a resposta à crise do capitalismo decorrente da expansão da intervenção do Estado, antagônica à forma mercadoria, ainda que necessária para sustentá-la. Após alguns anos de diagnóstico e de tateações (Crozier et alii, 1975), o neoliberalismo toma forma no final da década de 1970 como 'Reaganismo' e 'Thatcherismo', e consiste essencialmente em uma tentativa de recompor a primazia, e recuperar o âmbito, da produção de mercadorias. Renegando as formas social-democratas que acompanham o estágio intensivo, nega a crise estrutural e histórica do capitalismo e se volta às origens desse, do tempo do liberalismo -- daí o nome de neo-liberalismo". NEOLIBERALISMO. FAU-USP, Disponível em: <http://www.usp.br/fau/docentes/depprojeto/c_deak/CD/4verb/neolib/index.html>. Acesso em: 05 out. 2009. "A política neoliberal foi inaugurada no Chile no período do ditador Pinochet, entretando, foi na Inglaterra de Margareth Thatcher que ganhou seus contornos mais definitivos e acabados. Segundo Anderson (1995) o programa econômico dos governos Thatcher previam pelo menos a seguinte receita: a) contrair a emissão monetária; b) elevar as taxas de jutos; c) diminuir os impostos sobre rendimentos altos; d) abolir os controles sobre fluxos financeiros; e) criar desemprego massivo; e) aplastar as greves; f) elaborar legislação anti-social; g) cortar gastos públicos e finalmente; h) praticar um amplo programa de privatização". GENNARI, Adilson Marques. Globalização, neoliberalismo e abertura econômica no Brasil nos anos. Pesquisa \& Debate, São Paulo, v. 13, n. 2, p. 32, 2001. Disponível em: $<$ http://www.pucsp.br/pos/ecopol/downloads/edicoes/\%2821\%29adilson_marcos.pdf>. Acesso em: 03 abr. 2009.
} 
poder dos sindicatos e a redução do papel do Estado na economia (Estado mínimo), [e, para tanto,] empregou-se o receituário neoliberal: privatização das empresas estatais, flexibilização da legislação trabalhista, redução da carga fiscal e abertura comercial."110

A política neoliberal começou a ser delineada no Brasil, durante o governo Collor (início da década de 1990) e passou a introduzir mudanças que atingiram distintos aspectos do campo social. A adoção desse gênero de política, recomendada por organismos internacionais, levou o Estado a promover alterações em suas políticas econômica e social e, nesse sentido, as políticas trabalhistas passaram também a ser reformuladas, o que produziu reflexos na relação capital-trabalho, como relatado a seguir:

\begin{abstract}
"É nesse cenário de inserção subalterna na mundialização do capital que se acelerou o processo de reestruturação produtiva, aprofundando-se as tendências de transformação da estrutura de produção capitalista. $\mathrm{O}$ 'choque de competitividade', que percorreu os governos Collor, Itamar Franco e Fernando Henrique Cardoso, tornou-se um traço marcante da 'década neoliberal'. Desde o governo Collor constituíram-se diretrizes voltadas a dar maiores níveis de eficiência operacional, produtividade e competitividade próximas dos paradigmas internacionais." 111
\end{abstract}

Nesse contexto de globalização da economia e de pressão para flexibilizar a legislação trabalhista, proliferaram-se ideias de novos modelos de organização industrial centrados na concepção de uma empresa flexível, fluida e difusa. Para tanto, seria necessário um Direito do Trabalho do mesmo modo flexível, fluido e difuso, o que seria possível com uma modificação no regime de contratação de trabalhadores. Porém, o que se mostra favorável à liberdade de contratação e dispensa para o empregador, tem uma face perversa para os trabalhadores que se traduz em menos segurança no que toca à continuidade da relação de emprego, ao seu salário e, por conseguinte, ao seu sustento.

Medidas que permitem às empresas se desobrigar de encargos sociais, especialmente previdenciários, promovem insegurança no mundo do trabalho. Com o movimento de flexibilização foi permitida a redução dos salários, a compensação de horas trabalhadas, a diminuição da jornada de trabalho, entre outras. Como já apontado (ref. Interna), não foram necessárias reformas na legislação trabalhista para tanto, pois a

\footnotetext{
${ }^{110}$ CANDELORI, Roberto. Atualidades: o Consenso de Washington e o neoliberalismo. Folha Online, São Paulo, 14 nov. 2002. Disponível em: <http://www1.folha.uol.com.br/folha/educacao/ult305u11503.shtml>. Acesso em: 03 set. 2011.

${ }^{111}$ ALVES, Giovanni. Trabalho e sindicalismo no Brasil: um balanço crítico da "década neoliberal" (19902000). Revista de Sociologia e Política, n. 19, p. 71-94, nov. 2002.
} 
Constituição de 1988 já prevê a possibilidade de se utilizar acordos e convenções coletivas para negociar essas alterações.

Todavia, o momento em que os sindicatos foram chamados a representar os trabalhadores nessas negociações sobre assuntos muito sensíveis como redutibilidade salarial e jornada de trabalho, coincidiu com o período em que a representatividade sindical sentia os efeitos desagregadores da globalização sobre o mercado de trabalho.

As medidas neoliberais juntamente com a intensa mudança das estratégias das empresas, atingiram não somente as forças produtivas, mas também a estrutura da própria classe operária, que passou a experimentar um estado de desagregação.

Com a transformação no sistema capital-trabalho, "o emprego formal já não se faz necessário, a estabilidade não pode mais ser garantida pelo empregador, todo trabalhador é estimulado a ser empregador da sua força de trabalho". ${ }^{112}$ Ref51

O modelo de produção toyotista propõe a liberdade na exploração dos fatores de produção, dentre os quais a força de trabalho, e, para tanto, a flexibilidade da legislação torna-se indispensável, sendo que o próximo passo seria a desregulamentação do mercado de trabalho. Esta ocorre não somente pelas reformas legislativas, mas também pela redução da representatividade da coletividade dos trabalhadores.

Neste cenário de globalização, constata-se o aumento de relações de trabalho informais ou não abrangidas pela CLT, o que surte efeitos diretos na atuação sindical, porquanto suas bases perdem coesão. Nessa esteira, o enfraquecimento em sua capacidade organizativa e a redução da porcentagem de sindicalizados representam os maiores indícios do processo de crise.

O favorecimento da contratação de mão-de-obra informal ${ }^{113}$ contribui para a precarização das condições da relação de trabalho e, sem capacidade coletiva de organização, os trabalhadores são deixados à própria sorte, uma vez que lhes foi retirada a proteção estatal sem que se articulasse sua capacidade de negociação.

\footnotetext{
${ }^{112}$ SULZBACH, Mayra Taiza; DENARDIN, Valdir Frigo. op. cit.

113،Um estudo do Conselho Econômico e Social da ONU, Ecosoc, sugere que a globalização está levando a um aumento do setor informal. O "Relatório sobre a Situação Social do Mundo" revela que empregadores e governos estão tornando o mercado de trabalho mais flexível com o objetivo de aumentar a competitividade". GLOBALIZAÇÃO gera mais trabalho informal. Rádio das Nações Unidas, 29 nov. 2007. Disponível em: <http://www.unmultimedia.org/radio/portuguese/detail/153710.html>. Acesso em: 24 out. 2010.
} 
O desenrolar desse processo de escalada da informalização e a diminuição da contratação formal ${ }^{114}$ conduzem à formação de uma mão-de-obra desprotegida cada vez mais numerosa, situação esta que alimenta direta a precarização do mercado de trabalho. Tratam-se de trabalhadores temporários, terceirizados, subcontratados, ou admitidos por meio de outras modalidades de contratação, sem registro em carteira de trabalho. Para Jorge Mattoso, a precarização das condições de trabalho, aumentou "com a ampliação do trabalho assalariado sem carteira e do trabalho independente (por conta própria). Esse fenômeno pode ser identificado pelo aumento do trabalho por tempo determinado, sem renda fixa, em tempo parcial, enfim, pelo que se costuma chamar de bico. Em geral, a precarização é identificada com a ausência de contribuição à Previdência Social e, portanto, sem direito a aposentadoria. O processo de deterioração das relações de trabalho, com a ampliação da desregulamentação dos contratos temporários, de falsas cooperativas de trabalho, de contratos por empresa ou mesmo unilaterais". 115

Dados do Censo do IBGE de 2010 anunciaram, no final de 2011, novos dados sobre a taxa de desocupação dos brasileiros, "Segundo os dados, em outubro, o índice de desocupação atingiu 5,8\% da População Economicamente Ativa (PEA), o melhor desde dezembro de 2010. Os dados podem indicar que a informalidade ou a opção pelo empreendedorismo individual, que vem recebendo incentivo do governo federal, o que inclui a redução do valor de contribuição mensal à Previdência, são uma saída para a geração de renda daqueles que não conseguem uma ocupação formal no mercado de trabalho.",116

\footnotetext{
114، O Ministério do Trabalho divulgou dados que revelam uma queda no que se refere ao ritmo de crescimento de empregos formais. Segundo o órgão federal, desde outubro de 2008 o Brasil não registrava números tão ruins. Os dados do Cadastro Geral de Empregados e Desempregados (CAGED) mostram que foram abertas 126.143 vagas formais em outubro deste ano, o que representa queda de $38,4 \%$ se realizada comparação com o mesmo mês de 2010 , no qual houve o registro da criação de 204.804 empregos formais. Se observado o total de janeiro de 2011 até o mês de outubro, há o registro de 2,24 milhões de novos empregos com carteira assinada. O resultado aponta queda geral de 18,3\% de crescimento em relação ao mesmo período do ano passado, quando os números foram de 2,74 milhões de novas vagas formais". PIMENTEL, Jaqueline. O Censo 2010 que aponta distribuição desigual de renda e o Cadastro de Empregados que registra queda do crescimento de postos de trabalho formais reforçam a necessidade de intervenção sobre os DSS. Disponível em: <http://cmdss2011.org/site/2011/12/o-censo2010-que-aponta-distribuicao-desigual-de-renda-e-o-cadastro-de-empregados-que-registra-queda-docrescimento-de-postos-de-trabalho-formais-reforcam-a-necessidade-de-intervencao-sobre-os-dss/>. Acesso em: 04 abr. 2010.

${ }^{115}$ MATTOSO, Jorge. O Brasil desempregado: como foram destruídos mais de 3 milhões de empregos nos anos 90. São Paulo: Abramo, 1999. p. 8.

${ }^{116}$ PIMENTEL, Jaqueline. op. cit.
} 
De qualquer forma, é generalizada a percepção de que as difíceis condições vigentes no mercado de trabalho são particularmente adversas à imensa maioria de jovens "despreparados", projetando um cenário bastante problemático para o futuro. Se é entre os jovens que se encontram as mais elevadas taxas de desemprego, a dimensão e o avanço da informalidade entre os ocupados já antecipam problemas nos âmbitos da aposentadoria e da atenção dispensada aos idosos. ${ }^{117}$

Diante deste panorama, os sindicatos vêm sendo compelidos a promover transformações em seu perfil: de instrumento do qual os trabalhadores se serviam para lutar por melhores salários e pelo emprego, a um patamar, no qual a sindicalização tem papel cada vez menos relevante diante dos novos padrões de administração do trabalho.

\begin{abstract}
A linha contínua de degradação do mundo do trabalho que delineamos na "década neoliberal" significa um processo estrutural de transformações da objetividade e da subjetividade da classe trabalhadora no Brasil, em especial do setor industrial, com impactos decisivos no sindicalismo e nos movimentos sociais urbanos e rurais. É provável que os anos 1990 tenham sido um importante "elo de transição" para uma nova configuração do mundo do trabalho, de acordo com a nova dinâmica da acumulação capitalista mundial. ${ }^{118}$
\end{abstract}

Por todo o exposto, percebe-se que a reestruturação do modo de produção industrial e de gerenciamento de recursos humanos, almejando reduzir o tamanho da força de trabalho empregada e substituir o contrato de trabalho de longo prazo pelo trabalho temporário ou informal, causa impactos decisivos nas políticas públicas e, principalmente, no movimento sindical.

\title{
3.2. Análise econômica dos sindicatos
}

A análise econômica dos sindicatos consiste em examinar reflexos econômicos da atuação sindical no mercado de trabalho. Nesse ponto do presente trabalho, por meio da análise econômica dos sindicatos, pretende-se abordar a atuação sindical tomando-a como um fator de regulação do mercado de trabalho a fim de estudar

\footnotetext{
${ }^{117}$ QUADROS, Valdir. Classes sociais e desemprego no Brasil dos anos 1990. Economia e Sociedade, Campinas, v. 12, n. 1, p. 127, jan./jun. 2003.

${ }^{118}$ Id. Ibid., p. 127.
} 
seus reflexos e compará-la com outros elementos da mesma forma que podem provocar efeitos regulatórios nesse mercado.

Nessa ótica, o papel do sindicato seria o de atuar como um agente regulador sobre o equilíbrio de oferta e demanda de trabalho. Em um mercado no qual, até mesmo intuitivamente, se reconhece a superioridade da oferta de mão-de-obra em relação à demanda por ela, ou seja, em que há muito mais trabalhadores do que postos de trabalho, os sindicatos trabalhariam para que o preço de mercado da mão-de-obra não se tornasse vil.

Do ponto de vista de uma análise econômica dos sindicatos, são dois os principais aspectos a serem analisados: 1) a possibilidade dos sindicatos obterem melhores condições de trabalho aos seus representados, em especial salariais; e 2) hipótese de formação de cartéis pelo movimento sindical.

Em relação ao segundo aspecto, o debate econômico discute até que ponto os sindicatos são monopólios que distorcem a liberdade do mercado e, como tais, deveriam estar sujeitos à Legislação anti-truste. Os economistas a favor de tal teoria equiparam a organização sindical a um cartel de preços que acorda um preço único de oferta de trabalho e o impõe aos empregadores. Os autores contrários a essa orientação, por sua vez, afirmam que apenas algumas práticas sindicais, como o "closed shop" 119 apresentam tendências ao monopólio e que, empiricamente, os sindicatos não são capazes de impor condições unilaterais ao empresariado.

No presente trabalho, para discorrer sobre o aspecto econômico da atuação dos sindicatos, propõe-se limitar o enfoque à ação sindical em seu objetivo de obter melhores condições de trabalho, em especial salariais. Nesse sentido, três correntes se digladiam. A primeira nega a afirmação, entendendo que diferenças salariais decorreriam de características intrínsecas, independentes da existência do sindicato. O segundo grupo de especialistas entende que a ação sindical sempre obtém benefícios, não necessariamente salariais, ainda que em longo prazo. A terceira corrente segue os ensinamentos de Marshall, vinculando a efetividade da ação sindical à elasticidade ou não da demanda no mercado de trabalho.

\footnotetext{
${ }^{119}$ Por meio da cláusula closed shop o empregador compromete-se a contratar somente trabalhadores sindicalizados, estando a empresa "fechada" aos não sindicalizados.
} 
Tomando-se a terceira corrente como balizador da análise, pode-se proceder ao estudo da capacidade regulatória da atuação sindical sobre o mercado de trabalho. Ao se debruçar sobre a "elasticidade da demanda do mercado de trabalho", como se verá a seguir, revela-se exposta a situação de desequilíbrio dentro do mercado de trabalho no que tange a abundância do fator mão-de-obra e a escassez do fator postos de trabalho.

Assim como as proteções legisladas, aquelas que são negociadas prestamse a equilibrar a força do poder econômico do empregador e a fraqueza do poder individual dos trabalhadores. Com essa função em vista, os sindicatos podem exercer um papel regulador para equilibrar a abundância de mão-de-obra e a escassez de postos de trabalho, o que representaria a situação em que boa parte das condições de trabalho poderia ser estipulada negociadamente com atores em pé-de-igualdade. 


\section{AS LEIS DE MARSHALL NA ANÁLISE ECONÔMICA DOS SINDICATOS}

No que concerne ao entendimento da terceira corrente de pensamento econômico acima exposta, parte-se da ideia de que os sindicatos atuam de forma a diminuir a elasticidade da demanda por trabalho para proteger a categoria de trabalhadores que representam.

Na teoria econômica, o termo elasticidade significa sensibilidade. Quando se afirma que a demanda de um bem é elástica, isto quer dizer que os consumidores desse bem são sensíveis a alterações no seu preço e a sua elevação diminuirá a demanda, ao passo que a sua diminuição, aumentará a demanda por esse bem. Por outro lado, afirmar que a demanda do bem é inelástica quer dizer que os consumidores desse bem não mudarão seu comportamento em virtude de variações em seu preço. ${ }^{120}$

Propõe-se, portanto, estudar aspectos do mercado de trabalho pela ótica da demanda por trabalho, tendo a mão-de-obra como o bem desse mercado, cujos consumidores são os empregadores e o preço é o salário pago. Nesse quadro, abordaremos alguns mecanismos de atuação dos sindicatos para influenciar a elasticidade da demanda por trabalho.

\subsection{As Leis de Marshall}

Marshall propôs quatro enunciados que ilustram o movimento da elasticidade da demanda por trabalho:

$\mathbf{1}^{\text {a }}$ Lei de Marshall: Se o trabalho pode ser substituído facilmente por capital no processo produtivo, com o aumento dos salários as firmas substituirão trabalhadores por máquinas;

\footnotetext{
${ }^{120}$ VICECONTI, Paulo Eduardo V.; NEVES, Silvério das. Introdução à economia. 2. ed. São Paulo: Frase Ed, 1997. p. 63.
} 
$2^{\text {a }}$ Lei de Marshall: Se há elasticidade na demanda do produto ${ }^{121}$, aumentos de salário serão repassados para o preço dos produtos, afetando negativamente sua demanda, reduzindo a quantidade produzida e, por fim, a demanda de trabalhadores;

$3^{\text {a }}$ Lei de Marshall: Com o aumento dos salários, as empresas demandarão outros fatores de produção. Se a oferta desses fatores for elástica, o aumento na sua demanda não fará seu preço subir, viabilizando a substituição de trabalho por outros fatores;

$4^{\text {a }}$ Lei de Marshall: Se a participação dos salários no custo total é grande, o aumento nos salários causa impacto nos custos e a firma tenderá a desempregar trabalhadores para manter seu equilíbrio financeiro.

Essas quatro "leis" de Marshall trazem como variáveis para a análise do mercado de trabalho os fatores de que o empresário dispõe para organizar a sua atividade produtiva: força de trabalho, capital e máquinas. Articulando esses três elementos, a empresa se amolda às condições que lhe são impostas pela economia nacional em que está inserida. Elevações, por exemplo, no preço da mão-de-obra, no preço do capital ou no preço das máquinas exercerão pressões que provocarão resposta do empresário para conseguir manter-se em atividade. A sua reação será manipular os outros fatores de que dispõe para assimilar a variação na conjuntura econômica sem deixar que sua capacidade produtiva seja aniquilada.

"O mundo de Marshall tem dois grupos de agentes, os consumidores e
os produtores, que se relacionam mutuamente de forma tal que, dentro
de certas condições ambientais concretas, espera-se que um certo preço
faça com que a quantidade demandada seja igual à quantidade
produzida. O sistema terá, pois, que conter ao menos três variáveis
endógenas básicas: o consumo, a produção e o preço. O objetivo final
de Marshall é, portanto, o de construir, baseado nas relações entre oferta
e demanda, um modelo de mercado para aplicar como são determinados
os níveis destas variáveis".

Como acima indicado, pode-se afirmar que o consumo de empregos é determinado pelo empresário, a produção é a quantidade de mão-de-obra disponível e o preço é a remuneração.

\footnotetext{
${ }^{121}$ Elevações no preço do produto reduzirão a sua demanda, pois os consumidores desse bem são sensíveis a aumentos.

${ }^{122}$ LIMA, Gerson. Uma interpretação da curva de oferta de Marshall e a arquitetura de uma moderna Teoria da Oferta e Demanda. Revista Econômica, v. 2, n. 4, p. 63, dez. 2000. Disponível em: <http://www.uff.br/revistaeconomica/v2n2/4-gersonlima.pdf>. Acesso em: 23 set. 2011.
} 
No que tange às dificuldades dos sindicatos em assimilar os reflexos da economia globalizada e articular-se como acima sugerido, Hélio Zylbersztajn aponta o desemprego, a desindustrialização, a desregulamentação, a privatização e a inovação tecnológica como algumas variáveis relevantes que atuam sobre o mercado de trabalho. Nesse sentido, propõe ser possível olhar para essa questão sob a ótica oferecida pelas Leis de Marshall:

\begin{abstract}
"As quatro leis de Marshall descrevem exatamente como atuam as variáveis que afetam a elasticidade da demanda de trabalho. De acordo com essas leis, a elasticidade da demanda de trabalho é grande quando:
\end{abstract}

a) Trabalho e capital podem ser substituídos facilmente no processo produtivo. Nessas condições, se o salário aumentar, as firmas o substituirão por máquinas, desempregando trabalhadores.

b) A elasticidade de demanda do produto é grande. Nesse caso, se o salário aumentar, as firmas tentarão repassar o aumento de custo para os preços, causando redução na demanda do produto, que por sua vez provoca redução na quantidade produzida e, novamente, demissão de trabalhadores.

c) A elasticidade de oferta de outros fatores de produção é grande. Se o salário aumentar, as empresas demandarão mais dos outros fatores de produção. Se a oferta desses fatores for elástica, o aumento na demanda desses fatores não acarretará um acréscimo muito grande nos seus preços, viabilizando a substituição e, novamente, desempregando trabalhadores.

d) A participação dos salários no custo total é grande. Nesse caso, um aumento nos salários causa um impacto grande nos custos, que, novamente tende a desempregar trabalhadores." 123

\title{
4.2. A mão-de-obra como produto
}

Nesse panorama, a força de trabalho se apresenta como o fator mais fácil de ser manuseado pela maioria dos empresários, sobretudo numa economia emergente como a brasileira, na qual há poucos mercados de tipos de ocupação naturalmente inelásticos (ocupações em que a oferta de trabalhadores é pequena, dada a sua especialização, ou para as quais o uso intensivo de mão-de-obra na produção seja

\footnotetext{
${ }^{123}$ ZYLBERSTAJN, Hélio. Sindicalismo, Leis de Marshall e globalização. Informações Fipe, n. 232, p. 18, jan. 2000.
} 
imprescindível $^{124}$ ). Em economias pouco desenvolvidas, a maioria dos trabalhadores são pouco qualificados e disputam os mesmos postos de trabalho, o que se revela extremamente favorável aos empregadores de quaisquer postos de trabalho.

Em um mercado cujo produto seja facilmente substituível, a demanda é extremamente elástica e o produtor desse bem não tem poder sobre o seu preço, pois se aumentá-lo, o demandante recorrerá a outro produtor que ofereça o mesmo bem pelo preço antigo. Além disso, é facilmente verificável a situação em que, a despeito do preço geralmente praticado, um dos produtores decide abaixar sensivelmente seu preço para aumentar sua fatia de participação.

Num mercado com essas características, a competição entre os produtores pode ser extremamente perigosa, pois dificilmente haverá limites mínimos de preço do produto, sendo provável encontrar produtores que ofereçam preços abaixo de seu custo mínimo para entrar no mercado ou solapar seus concorrentes.

Transportando esses aspectos para o mercado de trabalho, no qual o produto é a força de trabalho humana e o seu preço são os salários, vislumbra-se o pior dos panoramas sociais que um país pode apresentar. A China pode ser considerada um exemplo dessa situação, bem como a Índia. Tratam-se de países superpopulosos, com imensa oferta de mão-de-obra e demanda por trabalho limitada. Naturalmente, esses países se apresentam como uma ameaça para o mercado de trabalho global, pois suas empresas podem oferecer empregos por salários muito mais baixos do que os de qualquer outra parte do mundo e sempre terão milhares de trabalhadores ávidos por esses postos.

Países que não oferecem padrões mínimos de trabalho e remuneração podem ser apontados como detentores de mercados de trabalho que promovem competição desleal com o resto do mundo. A falta de regulação do mercado de trabalho permite que se pratiquem salários baixíssimos nesses países, o que se revela muito vantajoso para as empresas que poderão oferecer seus produtos por preços competitivos no mercado internacional. Todavia os custos sociais que advêm desse regime de mercado e da sua manutenção prolongada podem ser desastrosos não só para o próprio país, como para o resto dos países que consomem os produtos elaborados nessas condições.

\footnotetext{
${ }^{124}$ Porém, mesmo que o uso de mão-de-obra seja intensivo, a oferta de trabalhadores pode ser grande se não houver necessidade de qualificação.
} 
Num círculo vicioso, a produção dos outros países, que possuem mercados de trabalho regulados, podem não ser capazes de competir com esses produtos e serem obrigados a fechar empresas ou transferir suas plantas para lugares em que a oferta de mão-de-obra seja farta e seja possível achatar salários. Esses países podem, por fim, ver a renda produtiva nacional diminuir e, por conseguinte, o poder aquisitivo de seus cidadãos, que deixarão de consumir e quebrando um dos elos fundamentais da cadeia econômica.

\subsection{A regulação do mercado de trabalho e o papel dos sindicatos}

Para prevenir tais situações, são empregadas há séculos medidas protetoras de mercado. Os mecanismos mais primitivos talvez sejam as tarifas alfandegárias que permitem sobretaxar a importação de produtos com vistas a proteger a produção nacional. Atualmente, há diversos outros mecanismos de salvaguarda da economia interna, inclusive sobre mercados de câmbio, fundos ou ações.

Nesse rol, deve-se incluir a regulação do mercado de trabalho como um mecanismo indispensável não só por ter reflexos na competitividade dos produtos no mercado, como porque preserva a integridade do tecido social e a paz entre seus cidadãos. Pelas situações acima expostas, principalmente após o movimento de globalização verificado nas últimas décadas, a necessidade de regulação do mercado de trabalho transcende o âmbito nacional para alcançar a urgência de que se estabeleçam padrões mínimos de trabalho em todos os países que participam da economia global.

As leis de Marshall representam bem em quais pontos não só os sindicatos devem ser chamados a atuar, mas também o Estado, que se apresenta como o ente regulador supremo inclusive nos países mais liberais. Atualmente, o debate deve ir além da simples ideia da hipossuficiência do trabalhador perante o empregador. Pode-se analisar por uma ótica ampliada, percebendo que a hipossuficiência pode recair sobre a economia inteira perante outras economias se não houver uma concertação internacional que estabeleça standards mínimos de condições de trabalho. 
De qualquer modo, a regulação nacional do trabalho é mais simples de ser realizada e sempre será necessária para o mercado de trabalho. Como visto, a par de alguns mercados de tipos de ocupação, cuja demanda seja naturalmente inelástica, no geral, a demanda no mercado de trabalho é elástica porque a oferta de mão-de-obra é grande. Não se pode escapar dessa realidade.

Sobre a relação das leis de Marshall e a interferência sindical no equilíbrio de preço do mercado de trabalho, Hélio Zylbersztajn observa que:

\begin{abstract}
"Do ponto de vista dos trabalhadores, é sempre interessante que a demanda de trabalho seja inelástica. As firmas, ao contrário, desejam que essa demanda seja elástica, para poder resistir às pressões salariais. As leis de Marshall deixam inferir, portanto, quais são os mecanismos pelos quais se pode afetar a elasticidade da demanda de trabalho. À luz dessas leis, pode-se interpretar, por exemplo, muitos dos comportamentos típicos dos sindicatos. Os sindicatos no mundo todo sempre tentaram influenciar a elasticidade de demanda de trabalho, na direção dos interesses dos trabalhadores. São objetivos típicos dos sindicatos, por exemplo: a restrição às inovações tecnológicas (para reduzir a facilidade de substituição de trabalho por capital); a restrição ao uso de trabalhadores não sindicalizados (para reduzir a possibilidade de substituir trabalho sindicalizado por trabalho não sindicalizado) e a oposição ao livre comércio (para reduzir a elasticidade de demanda do produto)." $" 125$
\end{abstract}

\title{
4.4. A proibição da dispensa imotivada para diminuir a elasticidade do mercado de trabalho
}

Perante situações em que a força de trabalho humana é tratada como um insumo de produção qualquer, faz-se necessário adotar mecanismos garantidores de que a mão-de-obra não fique à mercê das forças de oferta e demanda naturais de quaisquer mercados.

É tradicional a ideologia de que a força de trabalho não é um produto de comércio e não pode ser deixada ao sabor do laissez faire, laissez passer. Todavia, somente com a instituição de mecanismos de proteção e garantias relativas ao trabalho (atualmente necessárias supranacionalmente), torna-se possível prevenir que os empregadores dispensem à mão-de-obra um tratamento diferente do que usam para

\footnotetext{
${ }^{125}$ ZYLBERSTAJN, Hélio. op. cit.
} 
negociar insumos não-humanos de produção. Se não houver proteção legislativa ou representação coletiva contrabalanceadora do poder econômico dos empregadores, não será por livre e espontânea vontade que estes tratarão os trabalhadores sob o primado da dignidade humana.

Nesse contexto de economia globalizada e, por conseguinte, mercados de trabalho globalizados, os fatores que sensibilizam a demanda por trabalho podem ficar facilmente fora do alcance dos sindicatos. Como aponta Hélio Zylbersztajn:

\begin{abstract}
"A globalização retirou muito da antiga influência dos sindicatos sobre a demanda de trabalho nos respectivos países. Em consequência, a elasticidade de demanda de trabalho aumentou em todos os países. As condições previstas pelas Leis de Marshall se verificaram, por diversas razões. Primeiro porque a globalização aumentou extraordinariamente a mobilidade do capital. Como as grandes corporações alocam seus recursos em mercados globais, a produção deixou de ser um evento local ou mesmo regional. Partes de um produto podem ser produzidas em locais diferentes e distantes, e transportadas para diversas linhas de montagem. Para abrigar essa nova forma de organizar a produção, mercados que eram mais fechados tiveram que se abrir. Ficou muito mais difícil para os sindicatos se defenderem das alternativas utilizadas pelas empresas para substituir trabalho sindicalizado e caro (dos países desenvolvidos) por máquinas e/ou outras formas de trabalho, não organizado e barato (dos países em desenvolvimento). Segundo, porque a inovação tecnológica ganhou extraordinário impulso e aumentou a facilidade de substituição de trabalho por capital. Terceiro, porque a abertura de mercado deve ter aumentado a elasticidade de demanda de muito produtos, especialmente os manufaturados, que são exatamente aqueles onde a presença sindical era maior." ${ }^{126}$
\end{abstract}

A respeito de garantias sobre a relação de emprego, vale trazer o exemplo de países europeus como Portugal, França, Inglaterra, Alemanha entre outros, que construíram seus Estados de Bem-estar Social partindo da premissa básica de que não deve haver dispensa sem justa causa. Esta constitui a proteção das proteções em relação ao emprego e possui reflexos valiosos como se desenvolverá a seguir.

A proibição de dispensa imotivada foi consolidada internacionalmente com a edição da Convenção 158 da Organização Internacional do Trabalho em 1982, décadas após o início da construção desses modelos de estado social no período pósguerra. Durante o pós-guerra, os países europeus se reconstruíram tendo a oportunidade

\footnotetext{
${ }^{126}$ ZYLBERSTAJN, Hélio. op. cit.
} 
de lançar novas bases para o desenvolvimento social, a fim de evitar as convulsões que experimentaram no início do século XX e desembocaram na guerra.

Desse modo, esses países estruturam seu tecido social instituindo mecanismos eficazes de assimilação de movimentos críticos da economia nacional, como pôde-se perceber com a crise econômica de 2008 que, apesar de ter abalado profundamente diversos desses países europeus, não provocou miséria e depauperação generalizada graças aos institutos de bem-estar social que, apesar de bastante desmontados desde os anos 1980, ainda oferecem segurança às contingências sociais.

\subsubsection{A internacionalização de regras trabalhistas e a Convenção 158 da OIT}

A Organização Internacional do Trabalho - OIT tem como objetivo a criação de convenções, normas, resoluções e recomendações que, admitidas pelos Estados signatários, podem ser aplicáveis diretamente no ordenamento interno ou podem ser objeto de regulamentação para, assim, serem aplicadas internamente.

As normas produzidas pela OIT advêm da análise comparativa das condições de trabalho entre os vários países membros. Suas convenções são previamente acertadas em reuniões anuais entre governos nacionais e representantes de empregados e de empregadores. Por fim, os documentos elaborados no âmbito da OIT são considerados instrumentos jurídicos que obrigam os Estados ao cumprimento das normas neles estabelecidas após a sua ratificação interna.

Um dos idealizadores do socialismo utópico no século XIX, Robert Owen ${ }^{127}$, tentou difundir pelo mundo a ideia de ampliação geográfica da aplicação do Direito do Trabalho, culminando com uma tentativa de uniformização no âmbito mundial: ${ }^{128}$

\footnotetext{
${ }^{127}$ Owen, nascido no séc. XIX, no País de Gales, "Começa a trabalhar como ajudante numa indústria têxtil que emprega 500 operários. Passa a gerente em 1791 e, em 1799, compra uma fiação com dois sócios em Lanarkshire, na Escócia. Convencido de que a mão-de-obra pode ser mais bem aproveitada em uma sociedade cooperativa, propõe, em 1819, a criação de associações nas cidades com até mil pessoas, para ocupar os desempregados". ROBERT Owen. Disponível em: <http://www.algosobre.com.br/biografias/robert-owen.html>. Acesso em: 15 maio 2011.

${ }^{128}$ SOUZA, Zoraide Amaral de. A Organização Internacional do Trabalho - OIT. Revista da Faculdade de Direito de Campos, ano 7, n. 9, p. 427, dez. 2006.
} 


\begin{abstract}
"Owen pugnava por uma intervenção efetiva do Estado nas relações trabalhistas, pelo menos numa tentativa de garantir direitos básicos, pois, na prática, o trabalhador era a parte menos favorecida da relação e muitas vezes sem qualquer direito. (...) No período de atuação de Robert Owen, podemos lembrar a revogação, pelo Parlamento Britânico, em 1824 , de artigos de lei que proibiam a associação de trabalhadores, que por sua vez motivou o sindicalismo a travar uma luta com a classe dominante no sentido de conquistar direitos para a classe operária. $\mathrm{Na}$ ocasião, Owen foi fundamental para dar conhecimento ao Estado, da necessidade de se estabelecer um limite máximo da jornada de trabalho, que na ocasião foi fixada em 10 horas". ${ }^{129}$
\end{abstract}

Muitos fatores contribuíram para provocar a tendência da internacionalização do Direito do Trabalho. De acordo com Arnaldo Süssekind vários eventos ocorreram em prol das questões trabalhistas no mundo: Primeira Conferência Internacional do Trabalho - Berlin, 1890; Organização Cristã do Trabalho - Berlim, 1897; Criação da Comissão para Organizar um Organismo Internacional do Trabalho 1897, Bruxelas; Criação da Comissão para Organizar um Organismo Internacional do Trabalho - Bruxelas, 1897; Congresso de Paris - Fundação Internacional para Proteção dos Trabalhadores - Paris, 1900; Criação da Associação Internacional de Proteção Legal dos Trabalhadores - Basileia, 1901; Congresso da Filadélfia; 1915; Recomendação para criação do Tratado de Paz - Inglaterra, 1916.. ${ }^{130}$

O primeiro passo determinante para essa internacionalização foi a criação de um organismo de proteção aos direitos dos trabalhadores, durante a Conferência de Paris, em Versailles, em 1919. No Tratado de Paz de Versalhes, foi aprovada a criação de uma comissão internacional designada para estudar a regulamentação internacional do trabalho. Nesta mesma Conferência, foi aprovada a criação de um organismo denominado Organização Internacional do Trabalho - OIT. ${ }^{131}$

Em 1944, com a Declaração de Filadélfia, é que foram definidos os objetivos, os princípios e a política da Organização Internacional do Trabalho, que se

\footnotetext{
129، 'O posicionamento de Robert Owen não nasceu ao acaso, talvez tenha sido fruto de sua condição de empresário, e ainda, de haver naquele momento histórico a tese de que o Estado tinha por finalidade assegurar um mínimo de direitos irrenunciáveis. Averbe-se ainda que a Revolução Francesa de 1789 que buscava a adoção da filosofia liberal-individualista, na qual havia o princípio da igualdade jurídicopolítica de todos os cidadãos, valorizando a liberdade de contratar". SOUZA, Zoraide Amaral de. op. cit., p. $427-428$.

${ }^{130}$ SÜSSEKIND, Arnaldo. Convenções da OIT. São Paulo: LTr, 2000. p. 85-97.

${ }^{131}$ VIANNA, Segadas. Direito coletivo do trabalho. São Paulo: LTr, 1972. p. 45.
} 
firmou sob a bandeira de que "a paz, para ser universal e duradoura deve assentar sobre a justiça social"

A criação da OIT foi motivada por três motivos: para melhorar as condições de trabalho; por motivos políticos e econômicos. ${ }^{132}$ Aos poucos a Organização Internacional do Trabalho, por meio de suas convenções e recomendações, começou a regular, no cenário internacional, as relações trabalhistas.

A atuação da OIT, nesse panorama de relações de trabalho internacionais, acontece por meio da adoção de recomendações e convenções que, uma vez ratificadas pelos países, passam a fazer parte do direito nacional

Com a adoção de novas tecnologias de produção industrial, também cresceu a mão-de-obra entre as fronteiras, o que, na lição de Amauri Mascaro Nascimento, "apresenta problemas específicos decorrentes da mobilidade da força de trabalho entre as fronteiras à procura de novo emprego ou em sequiência do mesmo emprego, pondo-se o trabalhador, em outro País, na situação de estrangeiro submetido, até mesmo e conforme o caso, a três ordenamentos jurídicos, o do País em que está prestando o serviço, o de seu País de origem e o ordenamento internacional, em alguns casos comunitário. A mobilidade do capital tem atuado no sentido de provocar a ampliação desses ordenamentos e a necessidade de estabelecer regras que serão aplicáveis". ${ }^{133}$

A preocupação da OIT, com a existência de uma globalização justa, que respeite os direitos humanos, foi palco, em 1997 da 85ª Reunião da Conferência Internacional do Trabalho, sendo que, no ano seguinte, foi criada a Declaração Relativa aos Princípios e Direitos Fundamentais no Trabalho.

A Organização Internacional do Trabalho promoveu, ao longo dos anos,
sucessivas transformações conceituais, tais como, paz universal
vinculada à justiça social, relacionamento entre Estados-membros e
organismos internacionais e regionais especializados na matéria,

${ }^{132}$ STÜRMER, Gilberto. A liberdade sindical na Constituição da República Federativa do Brasil e sua relação com a Convenção 87 da Organização Internacional do Trabalho. Porto Alegre: Livr. do Advogado Ed., 2007. p. 127.

${ }^{133}$ NASCIMENTO, Amauri Mascaro. Curso de direito do trabalho. São Paulo: Saraiva, 2003. p. 14. 
sistema de convenções internacionais, preocupação com os diversos aspectos ligados à figura do trabalhador e ao seu trabalho." 134

Em 2008, a OIT adotou a Declaração da OIT Sobre Justiça Social para uma Globalização Justa ${ }^{135}$ durante a Conferência Internacional do Trabalho em sua $97^{a}$ Sessão Ordinária.

A Declaração prevê um conjunto de mudanças no funcionamento tanto da Organização, como de seu secretariado: uma agenda das Conferências alinhada com os quatro objectivos estratégicos; a consolidação de programas de trabalho digno por país; a possibilidade de, numa base voluntária, se proceder regularmente a estudos por país, como é prática noutras organizações internacionais; o reforço da capacidade de investigação, tratamento e difusão da informação.

A Declaração estabelece um novo quadro, a partir do qual a OIT poderá ser mais eficaz no apoio aos esforços dos seus mandantes para promover maior justiça social e um processo de globalização mais justo e inclusivo. ${ }^{136}$

\subsubsection{A proibição de dispensa imotivada constante na Convenção 158 da OIT}

A Convenção 158, aprovada em 1982 em Genebra, na 68 Reunião da Conferência Internacional do Trabalho da OIT, tem como assunto a garantia do emprego contra a dispensa imotivada, estabelecendo que um empregado só poderá ser desligado se a empresa estiver com dificuldades econômicas, em processo de mudança tecnológica ou por ineficiência do próprio empregado.

\footnotetext{
${ }^{134}$ BARROS, Cássio Mesquita. Direito internacional do trabalho. Mesquita Barros Advogados. Disponível em: $\quad<h t$ tp://www.mesquitabarros.com.br/index.php?option=com_content\&view=article\&id=25:direitointernacional-do-trabalho\&catid=7:artigos\&Itemid=3\&lang=pt>. Acesso em: 27 nov. 2010.

${ }^{135}$ ORGANIZAÇÃO INTERNACIONAL DO TRABALHO. Declaração da OIT Sobre Justiça Social para uma Globalização Justa. Adoptada pela Conferência Internacional do Trabalho na $97^{a}$ Sessão, Genebra, 10 de Junho de 2008.2 Disponíovel em: $<$ http://www.ilo.org/public/portugue/region/eurpro/lisbon/pdf/resolucao_justicasocial.pdf $>$. Acesso em: 28 set. 2009.

${ }^{136}$ OIT adopta Declaração sobre a justiça social para uma globalização justa. OIT Lisboa, ano 6, n. 15, set. 2008. Disponíivel em: <http://www.ilo.org/public/portugue/region/eurpro/lisbon/pdf/newsl_15.pdf>. Acesso em: 30 set. 2009.
} 
O ponto essencial da Convenção $n^{\circ} 158$ é o fato de estar baseada no princípio de que o emprego é um bem social a ser preservado, proibindo a demissão de um trabalhador sem que haja justificativa para tanto.

Atualmente, apenas 34 dos 180 países que compõem a OIT assinaram a Convenção 158. Quase todos os signatários são nações de pequena relevância na economia global como Camarões, República do Congo, Etiópia, Gabão, Iêmen, Lesoto, Maluí, Macedônia, Marrocos, Moldávia, Montenegro, Namíbia, Nigéria, Papua-Nova Guiné, República Centro-Africana, Santa Lúcia, Sérvia, Ucrânia, Uganda, Venezuela e Zâmbia. Por outro lado, dentre os países mais desenvolvidos que não ratificaram a convenção podemos citar Japão, Reino Unido, Estados Unidos e Alemanha. Da mesma forma, além da Argentina e México, não assinaram a Convenção ${ }^{\circ} 158$ três dos quatro países que compõem o BRIC - Rússia, Índia e China.

No Brasil, o Congresso Nacional, através do Decreto Legislativo n. $68^{137}$, de 16 de setembro de 1992, aprovou a Convenção 158 da OIT. Em 1995, esta Convenção foi ratificada pelo Governo, entretanto sua eficácia jurídica só se verificou foi por meio do Decreto n. 1.855, de 10 de abril de 1996, no qual em seu texto está decretado em seu art. 1': “A Convenção número 158, da Organização Internacional do Trabalho, sobre o Término da Relação de Trabalho por Iniciativa do Empregador, assinada em Genebra, em 22 de junho de 1982, apensa por cópia ao presente Decreto, deverá ser executada e cumprida tão inteiramente como nela se contém". Passados sete meses, no mesmo ano, através do Decreto n. 2.100, de 20 de dezembro, o então Presidente da República Fernando Henrique Cardoso, anuncia que a Convenção 158, deixa de vigorar no Brasil.

Para a Confederação Nacional da Indústria ${ }^{138}$, a adoção desta Convenção desestimularia o crescimento da economia, aumentaria os custos da empresa e acabaria sendo prejudicial também para o trabalhador, inibindo a geração de empregos e, por fim,

\footnotetext{
${ }^{137}$ DECRETO LEGISLATIVO No 68, DE 1992: Aprova o texto da Convenção $\mathrm{n}^{\circ}$ 158, da Organização Internacional do Trabalho (OIT), sobre o Término da Relação do Trabalho por Iniciativa do Empregador, adotada em Genebra, em 1982, durante a 68ª Sessão da Conferência Internacional do Trabalho.

${ }^{138}$ Em 08/07/1996, a Confederação Nacional do Transporte (CNT) e a Confederação Nacional da Indústria (CNI) ajuizaram, perante o Supremo Tribunal Federal, a Ação Direta de Inconstitucionalidade (ADIn) n. 1.480, com pedido de concessão liminar da tutela jurisdicional. Por meio dessa ação, requeriam a declaração da invalidade constitucional do Decreto Legislativo n. 68, de 16/09/1992, que aprovou a Convenção n. 158, e do Decreto n. 1.855, de 10/04/1996, que cuidou de promulgá-la.
} 
elevando o desemprego, "com uma sistemática cara e complexa como essa, as empresas relutam em abrir vagas". 139

De acordo com Ericson Crivelli, "o que vemos é a política do jogo bruto, o empregador pode demitir a qualquer momento, sem prestar contas de seus atos à sociedade".

\begin{abstract}
(...)
"Um contrato de prestação de serviços entre um escritório de advocacia e uma empresa não pode ser rompido de uma hora para outra sem uma boa justificativa, sob pena de sanções pesadas. Deve funcionar da mesma forma com a relação patrão-empregado, mas hoje a realidade é radical e perversa: temos de um lado a justa causa, que traz a idéia de ato grave, como uma violência, um roubo, que tira do demitido o direito à indenização. Do outro, temos a demissão arbitrária, sem necessidade de justificativa." $" 140$
\end{abstract}

Em 2007, após a $4^{\mathrm{a}}$ Marcha Nacional da Classe Trabalhadora, promovida pelas centrais sindicais: Força Sindical, CUT (Central Única dos Trabalhadores), Nova Central Sindical, CGTB (Central Geral dos Trabalhadores do Brasil) e a UGT (União Geral dos Trabalhadores), o Poder Executivo, encaminhou ao Congresso Nacional a Mensagem n. 59/2008 ${ }^{141}$ na qual foi solicitado que a Convenção 158 da OIT fosse ratificada e incorporada ao ordenamento jurídico brasileiro. ${ }^{142}$

Em 2010, o deputado Sabino Castelo Branco (PTB/AM) apresentou parecer favorável à ratificação, entretanto, curiosamente, em julho de 2011, o mesmo deputado apresentou parecer contrário sobre o texto da Convenção n ${ }^{\circ}$ 158, de 1982 alegando, entre outros motivos:

\footnotetext{
${ }^{139}$ CONVENÇÃO 158 da OIT. Tema importante para as empresas e para o país. CNI em Ação. Disponível em: <http://www.cni.org.br/portal/data/files/8A9015D0184D5A1501187679E6CE5B3D/Posicionamento\%20CNI\%2 0-\%20Conven\%C3\%A7\%C3\%A3o\%20158\%20da\%20OIT.pdf>. Acesso em: 03 set. 2011.

${ }^{140}$ Apud SINDICATOS DOS BANCÁRIOS E FINANCIÁRIOS DE SÃO PAULO. Convenção 158 da OIT: que bicho é esse? Disponível em: <http://www.spbancarios.com.br/noticia.asp?c=5792>.

${ }^{141}$ CÂMARA DOS DEPUTADOS. Mensagem $n .59$. Disponível em: <http://www.camara.gov.br/sileg/integras/539004.pdf>. Acesso em: 10 out. 2011.

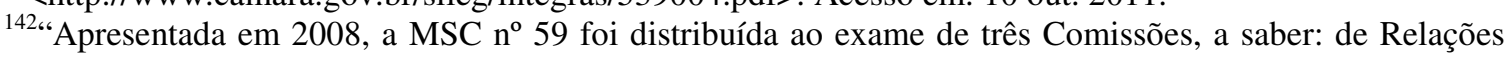
Exteriores e de Defesa Nacional (CREDN); de Trabalho, de Administração e Serviço Público (CTASP); e de Constituição e Justiça e de Cidadania (CCJC). Já apreciada pela CREDN, onde foi rejeitada, e tramitando na Comissão de Trabalho, a proposição chegou a receber inicialmente um parecer favorável à ratificação do ato internacional pelo Congresso de Sabino Castelo Branco (PTB/AM). No entanto, tal parecer foi requisitado pelo relator no início do mês de junho para que fosse realizado um reexame de seu teor, o que o levou a apresentação de um novo parecer que rejeita a matéria". DEPUTADO propõe rejeição da Convenção 158 da OIT. Disponível em: <http://www.cnf.org.br/noticias1.asp?id_noticia=1271>. Acesso em: 28 out. 2011.
} 
a) incentivo à informalidade no mercado de trabalho e agravamento da situação de desemprego;

b) discriminação no acesso ao mercado de trabalho, na medida em que, ao buscar proteger irrestritamente o contingente de trabalhadores empregados, termina criando obstáculos à entrada de outros grupos no mercado, como jovens à busca do primeiro emprego;

c) mais rigidez das regras para contratação e demissão de empregados, comprometendo investimentos no setor produtivo, bem como o empreendedorismo e a abertura de novas empresas, em especial de pequeno e médio porte;

d) desestímulo para o profissional buscar aperfeiçoamento e crescimento profissional;

e) restrição à adaptação das empresas às mudanças tecnológicas dificultando a adoção de novos comportamentos do mercado que estimulem formas alternativas de trabalho, a exemplo do trabalho a distância e da terceirização lícita de atividades;

f) redução das possibilidades de adaptação das empresas nacionais às exigências de competitividade nos mercados onde operam;

g) dificuldade de realização das negociações coletivas. ${ }^{143}$

Conforme bem salientou o professor Amauri Mascaro Nascimento: "o corporativismo está expresso na organização do Poder Legislativo, com a presença, no processo de elaboração legislativa, ao lado da representação política, da representação profissional e econômica, de modo a acrescentar na Câmara dos Deputados, além dos representantes eleitos por sufrágio universal, os deputados classistas, representando as forças produtivas, o capital e o trabalho."

\subsubsection{A Convenção 158 e o poder de dispensar empregados}

Para Ericson Crivelli, ao contrário de achar que esta Convenção representa estabilidade no emprego, ela cria um sistema de referência para a motivação da demissão do empregado. ${ }^{145}$ Em nenhum momento a proibição da dispensa imotivada visa provocar

\footnotetext{
${ }^{143}$ CÂMARA DOS DEPUTADOS. Histórico de pareceres, substitutivos e votos. Disponível em: $<$ http://www.camara.gov.br/proposicoesWeb/prop_pareceres_substitutivos_votos?idProposicao=383867> . Acesso em: 10 out. 2011.

${ }^{144}$ NASCIMENTO, Amauri Mascaro. Direito do trabalho na Constituição de 1988. 2. ed. São Paulo: Saraiva, 1991.p. 8.

${ }^{145}$ Apud SINDICATOS DOS BANCÁRIOS E FINANCIÁRIOS DE SÃO PAULO. Convenção $158 \mathrm{da}$ OIT: que bicho é esse? Disponível em: <http://www.spbancarios.com.br/noticia.asp?c=5792>.
} 
engessamento do mercado de trabalho ou impedir que os empresários disponham livremente de sua mão-de-obra. Deve-se ter em vista ainda que, no Brasil, desde a promulgação do Código Civil de 2002, institui-se legalmente a função social dos contratos e, nessa esteira, a liberdade de contratar deve ser exercida em razão e nos limites da função social do contrato.

Assim, sobretudo no que tange à contratação de empregados, que inegavelmente tem reflexos poderosos sobre a condição social da população, a liberdade do empregador em admitir, dirigir e assalariar deve ser exercida em razão e nos limites da função social do contrato, pois esses três verbos aludem a obrigações e prerrogativas contratuais.

Dentre as prerrogativas de ambas as partes no contrato de trabalho, encontra-se a de poder rescindi-lo. Apesar de a relação de emprego ser de trato sucessivo, em que é natural a continuidade, não é razoável desejar que ela não possa ser interrompida livremente pelas partes. Porém, esse mesmo princípio da continuidade da relação de emprego informa que as partes devem comportar-se com razoabilidade para realizar o seu término, esperando-se tanto do empregador como do empregado que seja dado aviso prévio para o seu encerramento.

A continuidade da relação de emprego é uma garantia tanto para o empregador, quanto para o empregado. Para organizar a sua atividade produtiva, o empregador quer ter certeza de que poderá contar com seus empregados dia após dia, sem ter a necessidade de negociar um contrato de trabalho toda vez que precisar deles. Para o empregado, essa garantia se reflete na sua subsistência, pois é imprescindível contar com aquele emprego e a remuneração que ele lhe proporciona periodicamente para o seu sustento e, eventualmente, o de sua família.

Desse modo, a ruptura da relação de emprego é uma situação delicada para ambas as partes. Porém para o empregado, que tem no salário o meio de subsistência alimentar próprio e de seus dependentes, a perda do emprego, mesmo mediante aviso prévio, pode se configurar como uma situação traumática e desesperadora.

Tendo isso em vista, um país que seu preocupa com o bem-estar de seus cidadãos e teme convulsões sociais, procura implementar diversos mecanismos que podem ser empregados para amenizar a situação. O próprio instituto do aviso prévio, previsto no ordenamento jurídico brasileiro, é um meio de se conceder um período para 
que o trabalhador saia de um emprego podendo já ter outro em vista para continuar trabalhando. Todavia, pelo que se tem notícia, o Brasil tem um dos menores períodos de aviso prévio dentre os países que adotam esse mecanismo.

\subsection{4. $O$ poder de dispensar e a elasticidade da demanda no mercado de trabalho}

Em Economia, diz-se que um mercado está em equilíbrio quando não há qualquer razão para alterar o comportamento dos seus participantes, pelo que não existe qualquer motivo para que a procura ou os preços desse mercado se alterem.

\footnotetext{
“...disseminou-se a ideia de que, se o governo não interferir, as forças de oferta e demanda levarão o mercado neoclássico a se auto-regularem no sentido de garantir o pleno emprego e o preço maios justo dos fatores de produção. Aparentemente, ao discutir esta ideia, tanto os economistas que a aceitam como os que a rejeitam desconsideram que ela só se refere ao modelo da concorrência perfeita. Caso o mundo real se afaste deste modelo, a teoria neoclássica afirma que o governo deverá intervir para que voltem a funcionar as forças de oferta e demanda, assegurando assim o retorno da autojustiça do mercado. Ou seja, neste caso, e pelo menos até que a imperfeição seja superada, as variáveis típicas de política econômica têm o poder de deslocar as curvas de oferta ou de demanda no sentido de promover um resultado socialmente mais justo". ${ }^{146}$
}

O poder de dispensar os empregados está diretamente ligado à elasticidade da demanda de trabalho. Alterações na demanda do produto, a facilidade de substituição da mão-de-obra por outros meios de produção ou a dimensão da folha no custo da empresa são fatores que invariavelmente produzirão reflexos na demanda por trabalho de uma empresa.

Se o produto se acumular em estoque porque a sua demanda diminuiu, não será necessário produzir mais e, em última instância, o empresário diminuirá seu quadro de empregados. Se for possível substituir mão-de-obra por outros meios de produção, o empregador, a rigor, não deixará de fazê-lo se isso diminuir seus custos de produção e aumentar seus lucros. Por fim, diminuir a dimensão que a folha de pagamento tem na

\footnotetext{
${ }^{146}$ LIMA, Gerson. op. cit., p. 61.
} 
planilha de custos é um objetivo sempre perseguido pelas empresas que podem fazê-lo e estas são a maioria em qualquer economia.

Assim, como mencionado, as Leis de Marshall revelam alguns pontos que podem ser atacados, sobretudo por meio de negociação coletiva, para diminuir a elasticidade do mercado de trabalho. Em países em que a atuação sindical é bem estruturada e surte efeitos para os empregados, os sindicatos geralmente se empenham em restringir inovações tecnológicas (para dificultar a substituição da mão-de-obra por máquinas), restringir uso de mão-de-obra não sindicalizada (para evitar o enfraquecimento do poder sindical) e opor-se ao livre comércio (para reduzir a elasticidade da demanda do produto). ${ }^{147}$

Dessas três linhas de atuação, a única que não representa um movimento inexorável da evolução dos seres humanos é a de filiação aos sindicatos. Porém, restringir inovações tecnológicas ou opor-se ao livre comércio são mecanismos perigosos que podem voltar-se contra a própria produção econômica e a saúde da economia nacional.

Em determinados mercados, pode ser interessante forçar os empresários a utilizar mão-de-obra intensiva, restringindo o uso de inovações tecnológicas que substituam postos de trabalho. Como exemplificou Hélio Zylbersztajn, o trabalho de atendentes em postos de gasolina (frentistas), cobradores de ônibus ou vendedores de porta-em-porta são ofícios que podem empregar muito e o custo social de substituí-los por call centers, máquinas ou simplesmente não oferecer os préstimos de um atendente seriam mais danosos socialmente do que os benefícios econômicos que poderiam advir da diminuição dos custos desses negócios.

Quanto à oposição que se poderia fazer ao livre comércio, volta-se ao mecanismo de proteção da economia nacional por meio de barreiras alfandegárias. Sem dúvida trata-se de uma ferramenta indispensável na condução da política macroeconômica de um país. Todavia, o crescente entrelaçamento dos mercados torna cada vez mais difícil o emprego de tais medidas unilateralmente. A Organização Mundial do Comércio - OMC - se apresenta como a instância supranacional de concertação comercial, porém, frente a países como Índia e China seu poder ainda é questionado, principalmente perante a economia de Estado chinesa.

\footnotetext{
${ }^{147}$ ZYLBERSTAJN, Hélio. op. cit., p. 17.
} 
Sem dúvida, não há como eleger um único mecanismo que se revele como a panacéia para a diminuição necessária da elasticidade do mercado de trabalho a fim de se manter a coesão social. Porém, é válido acrescentar a adoção da Convenção 158 da OIT como uma ferramenta inteligente e hábil a conferir maior segurança às relações de emprego e à sociedade como um todo, sem solapar a atividade econômica.

\subsubsection{A Convenção 158 e o poder de dispensar empregados}

Como já mencionado, em nenhum momento a proibição da dispensa imotivada impedirá o empregador de exercer sua liberdade de rescisão contratual. O que a Convenção 158 propõe é que o ato de dispensa não fique submetido exclusivamente ao juízo de conveniência e oportunidade do empregador, mas que ele seja analisado também por uma autoridade que, eventualmente, possa ser estatal ou sindical.

O artigo $4^{\circ}$ da Convenção 158 preconiza que "não se terminará a relação de trabalho a menos que exista uma causa justificada relativa à sua capacidade ou ao seu comportamento ou baseada nas necessidades de funcionamento da empresa, estabelecimento ou serviço". Por uma interpretação gramatical, depreende-se que a regra desse artigo manda, somente, que o empregador justifique a demissão que realizou ou pretende efetivar. Se a prestação de serviços deixa de ser necessária, certamente há uma justificativa plausível para o término da relação de emprego, ou ao menos deveria haver. A dispensa passa a ser um ato motivado do empregador, diminuindo o grau de discricionariedade sobre a sua prática. A autoridade competente para fazer a verificação do justo motivo poderá rever o ato, tornando ineficaz a dispensa, ou ratificá-la.

Não se pode negar que haveria limitação à liberdade de contratação, mas é preciso reconhecer que os ordenamentos jurídicos contemporâneos prevêem o princípio da função social dos contratos no regime do Direito Privado e impõem limitações dessa ordem inclusive por meio de regras legais com o fim maior de manter o nível de bemestar social de suas nações e prevenir desequilíbrios entre as partes contratantes.

O controle dos atos de dispensa poderia, por exemplo, ser feito por uma autoridade que analisasse a plausibilidade da justificativa face aos interesses de mercado 
e aos interesses sociais. Nos países que instituíram a proibição da dispensa sem justa causa, esse papel fica, geralmente, a cargo da Fiscalização do Trabalho.

No Brasil, onde a atuação sindical é pouco desenvolvida na pacificação de conflitos trabalhistas individuais e a fiscalização que o Ministério do Trabalho poderia exercer por meio de seus Auditores é subaproveitada, cabe primordialmente ao Judiciário desenvolver o papel de controle e tutela dos trabalhadores.

Com a possível ratificação da Convenção 158, seria necessário dar o poder de controlar essas dispensas a autoridades administrativas como os Auditores Fiscais do Trabalho para não sobrecarregar ainda mais a Justiça do Trabalho. Da mesma forma como é importante almejar que a maioria dos conflitos trabalhistas seja resolvida por comissões de fábrica, sindicatos ou árbitros particulares, a exemplo do que ocorre em países economicamente desenvolvidos, mas não ainda no Brasil.

\subsection{A proibição da dispensa imotivada para diminuir a elasticidade do mercado de}

\section{trabalho}

O reconhecimento pela Declaração Universal dos Direitos Humanos e pelo Pacto Internacional de Direitos Econômicos Sociais e Culturais ${ }^{148}$, na garantia ao direito ao trabalho e a segurança no emprego tornou-se uma tendência quase universal, pois o trabalho constitui um dos direitos fundamentais do homem.

Para Jean Pierre Marras, o trabalho pode ser definido como: "o somatório de tempo, energia e dedicação pessoal que um homem presta a outro, com vistas a receber, em trocam uma recompensa financeira, ou material, ou um mix de ambos, que lhe permite atender às suas necessidades pessoais e sociais". 149

"O direito ao trabalho leva também à verificação de que o homem, sozinho, não conseguiu produzir tudo de que necessitava para viver. A sociedade como um todo, sim, é capaz desta produção. Como cada um

\footnotetext{
${ }^{148}$ PACTO Internacional dos Direitos Econômicos, Sociais e Culturais. Adotada pela Resolução n.2.200-A (XXI) da Assembléia Geral das Nações Unidas, em 16 de dezembro de 1966 e ratificada pelo Brasil em 24 de janeiro de $1992 . \quad$ Disponível em: <http://www.oas.org/dil/port/1966\%20Pacto\%20Internacional\%20sobre\%20os\%20Direitos\%20Econ\%C 3\%B3micos, \%20Sociais\%20e\%20Culturais.pdf>. Acesso em: 28 set. 2009.

${ }^{149}$ MARRAS, Jean Pierre. Relações trabalhistas no Brasil: administração e estratégia. São Paulo: Futura, 2001. p. 3 .
} 
se beneficia do esforço conjunto da sociedade, o trabalho é um direito, mas é também um modo pelo qual é possível cada membro útil da sociedade dar a sua contribuição para o todo, somando-se às atividades dos demais, sendo este a razão pela qual o trabalho, de direito é também um dever, um dever social. Todos devem trabalhar para viver do seu trabalho e todos têm o dever de trabalhar para justificar a retribuição que recebem da sociedade na satisfação das necessidades comuns, pertencentes a todos e a cada um de seus membros da sociedade."

O desemprego é um fenômeno que acontece em decorrência do desequilíbrio entre a procura e a oferta de mão-de-obra. Para Jorge Luiz Souto maior, o problema do desemprego está ligado “...às políticas de macro-economia, considerados os arranjos comerciais e produtivos em escala mundial." ${ }^{\prime 151}$ Para o professor Souto Maior, o desemprego constitui o maior problema da atualidade.

Além das políticas de macro-economia, tem também ligação “...com a forma de regulação das relações de trabalho. A facilidade jurídica conferida aos empregadores para dispensarem seus empregados provoca uma grande rotatividade de mão-de-obra, que tanto impulsiona o desemprego quanto favorece a insegurança nas relações trabalhistas, e, ainda, fragiliza a situação do trabalhador provocando a precarização das condições de trabalho." ${ }^{152}$

Continua o professor ensinando que: "O principal papel a ser cumprido pelo direito do trabalho nos tempos presentes, portanto, é o de evitar o desemprego desmedido e despropositado, que apenas serve para incrementar a utilização de contratos que desconsideram os seus fins sociais e geram insegurança na sociedade." ${ }^{153}$ A garantia da proteção contra demissão arbitrária foi recepcionada pela Constituição Federal em seu art. $7^{\circ}$, inc. I.

\footnotetext{
"Ora, da previsão constitucional não se pode entender que a proibição da dispensa arbitrária ou sem justa causa dependa de lei complementar para ter eficácia jurídica, pois que o preceito não suscita qualquer dúvida de que a proteção contra dispensa arbitrária ou sem justa causa trata-se de uma garantia constitucional dos trabalhadores. Está-se, diante, inegavelmente, de uma norma de eficácia plena." 154
}

\footnotetext{
${ }^{150}$ NASCIMENTO, Amauri Mascaro. Direito do trabalho na Constituição de 1988, cit., p. 37.

${ }^{151}$ SOUTO MAIOR, Jorge Luiz. Proteção contra a dispensa arbitrária e aplicação da Convenção 158 da OIT. Revista de Direito do Trabalho, São Paulo, ano 30, n. 116, p. 110, out./dez. 2004.

${ }^{152}$ SOUTO MAIOR, Jorge Luiz. op. cit., p. 110.

${ }^{153}$ Id., loc. cit.

${ }^{154}$ Id., loc. cit.
} 
São varias as conceituações adotadas pela doutrina atribuídas ao termo justa causa. Amauri Mascaro Nascimento conceitua justa causa como "a ação ou omissão de um dos sujeitos da relação de emprego, ou de ambos, contrária aos deveres normais impostos pelas regras de conduta que disciplinam as suas obrigações resultantes do vínculo jurídico." 155

Para Valentin Carrion a justa causa se dá por meio de ato ilícito do empregado, quando há a violação de alguma obrigação contratual ou legal que permite ao empregador "a rescisão do contrato sem ônus (pagamento de indenização ou percentual sobre os depósitos do FGTS, $13^{\circ}$ salário e férias, estes dois proporcionais)."156

Evaristo de Moraes Filho conceitua a justa causa como uma falta grave onde a afeta a confiança na relação de emprego. Assim, o jurista considera a justa causa como “...todo ato doloso ou culposamente grave, que faça desaparecer a confiança e a boa-fé que devem entre elas existir, tornando assim impossível o prosseguimento da relação de emprego."

No final do século XX observamos que a intensificação do crescimento econômico e do avanço tecnológico, atingiu o mercado de trabalho, exigindo uma boa qualificação dos trabalhadores ou subordinando-os a empregos de baixos salários e também ao desemprego. Discorre-se atualmente sobre o "desemprego estrutural", que resulta das mudanças ocorridas no cenário econômico e causam desajustes no mercado de trabalho.

O aumento do desemprego, da informalidade no emprego e da terceirização são causas que fragilizam a ação sindical e afetam a representatividade do trabalhador. Essa nova cena nas relações de trabalho acaba prejudicando a dinâmica associativa do sindicato, desafiando-os à criação de novas estratégias para defesa própria e para a defesa do trabalhador e de seu salário.

"Diversos fatores específicos são apontados para explicar a decadência sindical. Entre eles estão o desemprego, a desindustrialização, a desregulamentação, a privatização, a inovação tecnológica, o

\footnotetext{
${ }^{155}$ NASCIMENTO, Amauri Mascaro. Curso de direito do trabalho. 16. ed. São Paulo: Saraiva, 1999. p. 583.

${ }^{156}$ CARRION, Valentin. Comentários à Consolidação das Leis do Trabalho. 20. ed. São Paulo: Ed. Revista dos Tribunais, 1995. p. 362.

${ }^{157}$ MORAES FILHO, Evaristo de. A justa causa na rescisão do contrato de trabalho. 3. ed. São Paulo: LTr, 1996. p. 105.
} 
crescimento da participação das mulheres no mercado de trabalho, além de outros. Todos esses fatores estão presentes, em maior ou menor grau, na transformação estrutural das economias nacionais, que é a globalização. Por essa razão, o declínio sindical costuma ser associado à globalização". ${ }^{158}$

Amauri Mascaro Nascimento leciona que "...diante de profundas transformações da economia de mercado, da descentralização das atividades pelas empresas, das terceirizações, da multifuncionalidade das empresas, do surgimento de novas atividades e profissões decorrentes das novas tecnologias, circunstâncias essas que, sem exceção, põem em completa destruição as categorias tradicionais e transformam as bases de representação sindical, que passam por uma transformação muito grande, imprevisível e sem controle". ${ }^{159}$

Ainda no campo sindical, José Pastore, enumera diversos fatores que têm comprometido, além da representatividade, a filiação e as finanças do sindicato de trabalhadores: “...o desemprego, a redução do das mega empresas, a multiplicação de pequenas, a desindustrialização, a expansão do comércio e serviços com unidades atomizadas, a terceirização de atividades, o avanço tecnológico, a privatização, a concorrência internacional, a globalização e a frenética movimentação de empresas e empregos de um país para outro". ${ }^{160}$

Segundo Leôncio Martins Rodrigues: “...os sindicatos, em todo o mundo, vivem hoje uma situação muito difícil, expressa na queda do número e da proporção de filiados e no declínio das taxas de greve, dois fenômenos indicativos do enfraquecimento do sindicalismo como instituição e do poder sindical como ator político" ${ }^{161}$ Continua o autor afirmando que: “...as características gerais da sociedade pós-industrial abrem pouco

\footnotetext{
${ }^{158}$ ZYLBERSTAJN, Hélio. op. cit., p. 18.

${ }^{159}$ NASCIMENTO, Amauri Mascaro. Perspectivas do direito sindical. Revista LTr, São Paulo, v. 63, n. 12 , p. 1595, dez. 1999.

${ }^{160}$ PASTORE, José. A filosofia da reforma sindical. José Pastore. Disponível em: <http://www.josepastore.com.br/artigos/rt/rt_241.htm>. Acesso em: 19 nov. 2011.

"A crise do sindicalismo atinge também as organizações patronais. Na verdade, o ambiente patronal é mais heterogêneo do que o dos trabalhadores. Ao lado das entidades propriamente sindicais, proliferam as associações setoriais que também se propõem a prestar serviços de utilidade para os empresários na defesa de seus interesses. Inúmeros novos sindicatos e federações patronais vêm desafiando o princípio da "unicidade sindical" e ameaçando o poder de monopólio garantido por lei ao 'sindicalismo oficial."” In PASTORE, José. A crise do sindicalismo. José Pastore. Disponível em: <http://www.josepastore.com.br/artigos/rt/rt_241.htm>. Acesso em: 19 nov. 2011.

${ }^{161}$ RODRIGUES, Leôncio Martins. Destino do sindicalismo. São Paulo: EDUSP; FAPESP, 2002. p. 11.
} 
espaço para a organização sindical, embora a extensão desse espaço possa ser diferente quando se avalia sociedades nacionais específicas" ${ } 162$

Com a globalização, a situação do mercado de trabalho se agravou levando os sindicatos a perderam a influência que detinham sobre a demanda de trabalho. A consequência disto é que a elasticidade da demanda de trabalho aumentou em todos os países. Para Hélio Zylberstajn, "as condições previstas pelas Leis de Marshall se verificaram por diversas razões"163.

Continua o autor elencando que, a primeira razão se deu com a globalização que aumentou a mobilidade do capital, a segunda razão se deve ao avanço tecnológico que concedeu a facilidade de substituir trabalho por capital e, terceiro, porque com a abertura do mercado houve aumento na elasticidade de muitos produtos:

"Como as grandes corporações alocam seus recursos em mercados
globais, a produção deixou de ser um evento local ou mesmo regional.
Partes de um produto podem ser produzidas em locais diferentes e
distantes, e transportadas para diversas linhas de montagem. Para
abrigar essa nova forma de organizar a produção, mercados que eram
mais fechados tiveram que se abrir. Ficou muito mais difícil para os
sindicatos se defenderem das alternativas utilizadas pelas empresas para
substituir trabalho sindicalizado e caro (dos países desenvolvidos) por
máquinas e/ou outras formas de trabalho, não organizado e barato (dos
países em desenvolvimento). Segundo, porque a inovação tecnológica
ganhou extraordinário impulso e aumentou a facilidade de substituição
de trabalho por capital. Terceiro, porque a abertura do mercado deve ter
aumentado a elasticidade de demanda de muitos produtos,
especialmente os manufaturados, que são onde a presença sindical era
maior."164

Hélio Zylberstajn enfatiza que com base nas Leis de Marshall, também se entende o porquê dos sindicatos terem maior resistência de sobrevivência, quando se trata das atividades no serviço público, "nessas atividades, a legislação e as circunstâncias políticas ofereceram aos sindicatos as condições para preservar diversas regras e políticas que impedem a substituição de funcionários públicos por outros trabalhadores."165

\footnotetext{
${ }^{162}$ RODRIGUES, Leôncio Martins. op. cit., p. 301.

${ }^{163}$ ZYLBERSTAJN, Hélio. op. cit., p. 18.

${ }^{164}$ Id. Ibid., p. 19.

${ }^{165}$ Id., loc. cit.
} 
Outro fator que facilita a sobrevivência dos sindicatos na representação dos setores públicos é o fato de esses setores não produzirem bens (serviços non tradables - serviços que não são passíveis de transação nos mercados internacionais). Esses bens não-transaccionáveis são mais imunes à abertura dos mercados gerada pela globalização. ${ }^{166}$

Desde sempre o papel do sindicato é a defesa dos direitos e interesses coletivos ou individuais da categoria, mas com a abertura do mercado de trabalho e, consequentemente com o aumento da elasticidade da demanda de trabalho, os sindicatos utilizam como estratégia para a manutenção de emprego e melhores salários, a redução da elasticidade da demanda de trabalho.

Sindicatos de países desenvolvidos defendem a proposta da Cláusula Social, que se trata da vinculação dos direitos trabalhistas mínimos às normas comerciais.

\begin{abstract}
"Os sindicatos de trabalhadores são os principais responsáveis pela defesa da inclusão da Cláusula Social no sistema internacional de comércio, tanto das iniciativas multilaterais quanto daquelas que assumem um caráter regional, ou mesmo unilateral. Desde quando se pratica intervenções de inclusão de Cláusulas Sociais, têm sido os sindicatos que mais pressionam, mobilizam e instigam os governos nacionais a assumirem posição de apoio a essa empreitada."
\end{abstract}

Na visão de Hélio Zylberstajn, novamente com base nas Leis de Marshall, entende-se porque os sindicatos defendem a proposta da Cláusula Social:

\begin{abstract}
"Uma vez adotada por todos os países, os trabalhadores daqueles países teriam instrumentos para restringir a substituição de trabalho sindicalizado dos países desenvolvidos por trabalho não sindicalizado e barato (trabalho precário, trabalho forçado, de crianças, etc.) dos países em desenvolvimento. E mais: uma Cláusula Social precisaria prever a operação de mecanismos de monitoramento, controle, avaliação, os quais teriam, certamente, caráter tripartite. Tudo isso criaria um grande espaço institucional para os sindicatos, em escala internacional."
\end{abstract}

\footnotetext{
${ }^{166}$ ZYLBERSTAJN, Hélio. op. cit., p. 19.

${ }^{167}$ CARNEIRO, Marco Aurélio da Silva. Não intervenção do estado nas relações de trabalho - cláusula social nos tratados internacionais. Revista do Superior Tribunal do Trabalho, Brasília, v. 67, n. 3, p. 140, jul./set. 2001.

${ }^{168}$ ZYLBERSTAJN, Hélio. op. cit., p. 19.
} 
$\mathrm{Na}$ apreciação da Cláusula Social pela OMC são os sindicatos que mais se mobilizam e estimulam os governos nacionais a assumirem posição de adesão a essa Cláusula por razões bem razoáveis, “...o desenvolvimento econômico não é um objetivo em si mesmo, mas atividade-meio que conduz a realização das necessidades humanas na defesa de alguns direitos fundamentais." 169

\footnotetext{
"Importante é o fato de que entre os países desenvolvidos e em desenvolvimento houve divergências ante a Cláusula Social, o mesmo não prosperou quanto aos movimentos sindicais.

A intuição é evidente, primeiro por se tratar de padrões e direitos mínimos, podendo estes serem reivindicados por quaisquer sindicatos, em qualquer parte do mundo.

Segundo, devido à sua ligação intrínseca com os direitos humanos fundamentais, retrata apelo humanitário.

Por fim devido ao caráter multilateral, sua apreciação pela OMC (Organização Mundial do Comércio) faz-se necessária de modo a inibir possíveis tensões entre movimentos sindicais de país acionado e aquele país que aprovou as sanções comerciais."
}

\subsection{Dispensa sem justa causa}

A despedida sem justa causa, também denominada como desmotivada, é a mais tradicional dentre as modalidades de dispensa. $\mathrm{O}$ empregador não tem a obrigação ou necessidade de informar ou justificar os motivos da dispensa, tendo o direito potestativo de rescindir o contrato de trabalho sem qualquer justificativa a respeito dos motivos que o levaram a tomar tal decisão.

${ }^{169}$ CARNEIRO, Marco Aurélio da Silva. op. cit., p. 140. 


\section{CONCLUSÕES}

Por todo o exposto, percebe-se que o mercado de trabalho não pode prescindir de mecanismos que equilibrem as forças da oferta de força de trabalho e da demanda por postos de trabalho. Por se tratar de um mercado cujo bem está diretamente ligado à dignidade humana, não é possível deixá-lo buscar o equilíbrio por conta própria, ou seja, autorregular-se, pois o resultado seria o aviltamento dos trabalhadores. Os tomadores de serviço sempre buscariam pagar os menores salários possíveis e os trabalhadores se sujeitariam a esses salários por não terem outra opção.

Nesse ponto, pode-se valer de exemplificação advinda da Teoria Geral do Direito Privado. O estudo do Direito Privado, no qual se inclui o Direito do Trabalho, identificou o fenômeno dos "contratos de massa", mais peculiares nas relações de consumo, em que não há liberdade de estipulação das cláusulas contratuais para uma das partes. O contrato de trabalho pode ser incluído nesse tipo, uma vez que a liberdade de contratação do trabalhador praticamente não existe, não só porque as condições em que o serviço será prestado são decididas pelo empregador, como pela premência que os trabalhadores têm para encontrar um emprego e garantir sua subsistência.

Nesse sentido, faz-se oportuno jogar novas luzes sobre a análise do poder do empregador sobre a relação de trabalho. Nos países europeus, já se superou a questão sobre a hipossuficiência econômica do trabalhador, sobretudo pela construção de Estados de Bem-estar Social que elevaram o nível de segurança social dos cidadãos. Porém, como mencionado, em larga medida esse padrão de seguridade foi alcançado por restrições impostas ao poder de dispensar injustificadamente os empregados.

O Direito do Trabalho tem se ocupado nos últimos anos, p. ex., em estudar aspectos do Assédio Moral, em que o empregador, valendo-se do poder que tem sobre o empregado e do temor deste pela demissão, abusa moralmente de seus subordinados. Pode-se estabelecer um paralelo entre o assédio moral e a dispensa sem justa causa no seguinte sentido: se o empregado é dispensado sem justo motivo para tanto, pode-se entender que o empregador está exorbitando de seu poder sobre a relação de emprego, ao por fim injustificademente a uma relação de trato sucessivo, em que há expectativa de sua continuidade tanto para a segurança da atividade econômica, quanto para a segurança pessoal do empregado. 
Desse modo, percebe-se que não é o sindicato simplesmente que deseja a inelasticidade da demanda no mercado de trabalho, mas os trabalhadores como um todo. O trabalhador pode decidir não se afiliar a um sindicato se este não se mostrar como um bom caminho para se obter melhores condições de trabalho. Porém, ele não deixará de almejar melhores situações de trabalho por não efetivar sua filiação a uma organização sindical.

No enfoque dado à Convenção n. 158 da OIT, o ato de dispensa perde discricionariedade ao ser submetido ao juízo de um terceiro à relação de trabalho. No Brasil, esse procedimento acabaria na Justiça do Trabalho, como já ocorre hoje. Mas, tendo em vista que o atualmente a legislação busca redimensionar o acesso ao judiciário, pode-se propor que os tribunais dêem mais fé às resoluções extrajudiciais dos conflitos diferentemente do que ocorre hoje em dia.

Percebe-se em outros países, como Portugal e França, que os sindicatos e a fiscalização do trabalho têm papéis mais atuantes no controle das dispensas. No Brasil, tentou-se conferir mais efetividade a soluções extrajudiciais a conflitos trabalhistas com as Comissões de Conciliação Prévias, mal recebidas pelo Judiciário. Porém, a ideia é de que o Judiciário Trabalhista se coloque como um avaliador da regularidade de procedimentos extrajudiciais de resolução das controvérsias, somente quando se apresentarem elementos suficientes que exijam a atuação do magistrado nesses casos, assim como mecanismos instituídos para acesso a Tribunais Superiores, como o da Repercussão Geral no Supremo Tribunal Federal.

Um dos possíveis efeitos da adoção da Convenção 158 seria o de que os empregadores passariam a tomar mais cuidado na contratação dos empregados e tenderiam a investir mais na sua qualificação, sabendo que não poderão dispensá-los com facilidade ou, p. ex., que deverão apresentar justificativas técnicas para legitimar a dispensa. ${ }^{170}$ Em sistemas que não restringem legalmente a dispensa sem justa causa, os sindicatos dispõem de mais essa reivindicação para incluir em sua pauta de negociação coletiva. Nos EUA, onde não há restrição legal à dispensa injustificada, esta proteção pode chegar aos trabalhadores por meio da atuação dos sindicatos. Além de todo o panorama da globalização, colocando mercados de trabalho internacionais em

\footnotetext{
${ }^{170}$ DICKENS, Linda; HART, Moira; JONES, Michael; WEEKES, Brian. The British experience under a statute prohibiting unfair dismissal. Industrial and Labor Relations Review, v. 37, p. 497, 1983-1984.
} 
competição pelos meios de produção, os sindicatos sofreram com a ideologia neoliberal que propõe o desmonte do estado de bem-estar social e da proteção do trabalho. ${ }^{171}$

Assim, faz-se necessário renovar o debate sobre a proteção ao trabalho, seja no que tange ao Direito Coletivo, dotando os sindicatos de mecanismos e de um ambiente mais favoráveis à negociação coletiva, seja em relação ao Direito Individual, instituindo instrumentos jurídicos modernos em relação aos que a CLT preconizou em 1943 e mais consentâneos com a nova realidade sócio-econômica que se consolidou ao longo das três últimas décadas.

Nesse bojo, percebe-se que o Princípio de Proteção do Direito do Trabalho nos países desenvolvidos não mais se assenta sobre a hipossuficiência do trabalhador, porém em países emergentes convive-se com as duas realidades ainda. Desse modo, não seria prudente propor flexibilização da legislação trabalhista nos mesmos termos que os países europeus, p. ex., mas poderiam ser adotados mecanismos como o da Convenção 158 que permitiriam proteger melhor os empregados, sem solapar a atividade econômica. Deve-se ter em vista ainda que, no Brasil, o poder dos empregadores sobre a relação de trabalho é bem maior comparativamente ao que se verifica nos países europeus, como exposto, ou nos EUA, onde a negociação coletiva consegue impor as restrições que em outros países seriam impostas pelo Estado.

\footnotetext{
171“Neo-liberalism has discredited the welfare state and the new economy has accelerated the breakdown of the traditional firm, which was the basis upon which unions were organized in developed non-socialist countries after World War II. This transformation in political ideology and economic reality has had a profound impact on the traditional supports for labor rights. Laws that protected and promoted trade unions have been undermined as the economy and the structure of enterprises have changed or have been refashioned to promote competition via individual contracting" (FUDGE, Judy, The new discourse of labor rights: from social to fundamental rights. Comparative Labor Law \& Policy Journal, v. 29, n. 1, p. 37, 2007).
} 


\section{REFERÊNCIAS BIBLIOGRÁFICAS}

ALMEIDA, Lúcio Rodrigues de. As leis imperativas e a CLT. LTr, Suplemento trabalhista, São Paulo, n. 179, 1994.

ALVES, Giovanni. Do "novo sindicalismo" à “concertação social”: ascensão (e crise) do sindicalismo no Brasil (1978-1998). Revista de Sociologia e Política, Curitiba, n. 15, p. 111-124, nov. 2000.

. Trabalho e sindicalismo no Brasil: um balanço crítico da "década neoliberal" (1990-2000). Revista de Sociologia e Política, n. 19, p. 71-94, nov. 2002.

AMORIM, Wilson Aparecido Costa de. Negociações coletivas no Brasil: uma análise do período 1990-2004. Disponível em: $<$ http://www.eclac.cl/brasil/noticias/noticias/3/34013/NegociacoescoletivasnobrasilWilso nAmorim.pdf>. Acesso em: 10 out. 2011.

ANTUNES, Ricardo. Os sentidos do trabalho: ensaio sobre a afirmação e a negação do trabalho. São Paulo: Boitempo, 2002.

BARROS, Alice Monteiro de. Curso de direito do trabalho. 3. ed. São Paulo: LTr, 2007.

BARROS, Cássio Mesquita. Direito internacional do trabalho. Mesquita Barros Advogados. Disponível em: $<$ http://www.mesquitabarros.com.br/index.php?option=com_content\&view=article\&id=2 5:direito-internacional-do-trabalho\&catid=7:artigos \&Itemid=3\&lang=pt $>$. Acesso em: 27 nov. 2010.

A influência italiana no direito do trabalho brasileiro. Mesquita Barros Advogados. Disponível em: $<$ http://www.mesquitabarros.com.br/index.php?option=com_content\&view=article\&id=5 7:a-influencia-italiana-no-direito-do-trabalhobrasileiro\&catid=7:artigos\&Itemid=3\&lang=en>. Acesso em: 27 nov. 2010.

BATALHA, Claudio H. M. Sociedades de trabalhadores no Rio de Janeiro do século XIX: algumas reflexões em torno da classe operária. Cadernos AEL, v. 6, n. 10/11, p. 4363, 1999. Disponível em: <http://www.ifch.unicamp.br/ael/website-ael_publicacoes/cad10/Artigo-2-p41.pdf>. Acesso em: 28 set. 2011. 
BERTOLIN, Patrícia Tuma Martins. Algumas reflexões sobre os impactos do comércio internacional sobre o mundo do trabalho. Revista do Departamento de Direito do Trabalho e da Seguridade Social, São Paulo, v. 2, n. 3, p. 53-60, jan./jun. 2007.

BOBBIO, Norberto. A era dos direitos. 11. ed. Rio de Janeiro: Campus, 1992.

BOITO JR., Armando; MARCELINO Paula. Brasil: o movimento sindical e popular na década de 2000. Observatorio Social de América Latina (OSAL), Buenos Aires, ene. 2002. Disponível em: <http://pt.scribd.com/doc/26232285/Brasil-o-movimento-sindicale-popular-na-decada-de-2000>. Acesso em: 10 out. 2011.

BONAVIDES, Paulo. Curso de direito constitucional. São Paulo: Malheiros Ed., 2006.

CABANELlAS, Guilhermo. Compendio de derecho laboral. Buenos Aires; Omeba, 1968.

CACCIAMALI, Maria Cristina. Globalização e processo de informalidade. Economia e Sociedade, UNICAMP, Instituto de Economia, Campinas, n. 14, p. 153-170, jun. 2000. Disponível

em:

$<$ http://www.eco.unicamp.br/docdownload/publicacoes/instituto/revistas/economia-esociedade/V9-F1-S14/06-Cacciamali.pdf>. Acesso em: 02 fev. 2011.

CÂMARA DOS DEPUTADOS. Histórico de pareceres, substitutivos e votos. Disponível em:

$<$ http://www.camara.gov.br/proposicoesWeb/prop_pareceres_substitutivos_votos?idProp osicao $=383867>$. Acesso em: 10 out. 2011.

Mensagem $\quad$ n. $59 . \quad$ Disponível em:

<http://www.camara.gov.br/sileg/integras/539004.pdf>. Acesso em: 10 out. 2011.

CANDELORI, Roberto. Atualidades: o Consenso de Washington e o neoliberalismo. Folha Online, São Paulo, 14 nov. 2002. Disponível em: <http://www1.folha.uol.com.br/folha/educacao/ult305u11503.shtml>. Acesso em: 03 set. 2011.

CARNEIRO, Marco Aurélio da Silva. Não intervenção do estado nas relações de trabalho - cláusula social nos tratados internacionais. Revista do Superior Tribunal do Trabalho, Brasília, v. 67, n. 3, p. 132-141, jul./set. 2001.

CARRION, Valentin. Comentários à Consolidação das Leis do Trabalho. 20. ed. São Paulo: Ed. Revista dos Tribunais, 1995. 
CARTA Encíclica Pacem in Terris do Sumo Pontífice Papa João xxiii. A Paz de Todos os Povos na Base da Verdade, Justiça, Caridade e Liberdade. Disponível em: <http://www.vatican.va/holy_father/john_xxiii/encyclicals/documents/hf_jxxiii_enc_11041963_pacem_po.html>.

CASTELLS, Manuel. A sociedade em rede. Tradução Roneide Venancio Majer com a colab. de Klauss Brandini Gerhardi. 8. ed. total. rev. e ampl. São Paulo: Paz e Terra, 1999. v. 1.

CATHARINO, José Martins. Tratado elementar de direito sindical. São Paulo: LTr, 1977.

CONVENÇÃO 158 da OIT. Tema importante para as empresas e para o país. CNI em Ação. Disponível

em: <http://www.cni.org.br/portal/data/files/8A9015D0184D5A1501187679E6CE5B3D/Posi cionamento\%20CNI\%20-\%20Conven\%C3\%A7\%C3\%A3o\%20158\%20da\%20OIT.pdf>. Acesso em: 03 set. 2011.

CORREIA, Marcus Orione Gonçalves. O contrato individual do trabalho no contexto neoliberal: uma análise crítica. Revista LTr, São Paulo, ano 67, n. 4, p. 422-429, maio 2003.

CRUZ, Sofia Alexandra. Uma cartografia do trabalho precário, as mulheres (des) alinhadas na precariedade. Porto: Sociologia, n. 12, 2002. Disponível em: <http://ler.letras.up.pt/uploads/ficheiros/1493.pdf>. Acesso em: 03 abr. 2009.

CUNHA, Rodrigo Giostri da. Análise do modelo corporativista italiano. Revista do Departamento de Direito do Trabalho e da Seguridade Social, São Paulo, v. 1, n. 2, jul./dez. 2006.

\section{DECLARAÇÃO DA OIT SOBRE OS PRINCÍPIOS E DIREITOS FUNDAMENTAIS NO TRABALHO. Disponível em:} $<$ http://www.oit.org.br/sites/default/files/topic/oit/doc/declaracao_oit_547.pdf>. Acesso em: 22 nov. 2010.

DEPUTADO propõe rejeição da Convenção 158 da OIT. Disponível em: <http://www.cnf.org.br/noticias1.asp?id_noticia=1271>. Acesso em: 28 out. 2011.

DICIONÁRIO Político. AFL (American Federation of Labor). Disponível em: $<$ http://www.marxists.org/portugues/dicionario/verbetes/a/afl.htm>. Acesso em: 23 mar. 2011. 
DICKENS, Linda; HART, Moira; JONES, Michael; WEEKES, Brian. The British experience under a statute prohibiting unfair dismissal. Industrial and Labor Relations Review, v. 37, 1983-1984.

FERNANDES, António Monteiro. Direito do trabalho. 13. ed. Coimbra: Almedina, 2006.

FERRÃO, João. Entender o actual processo de «terciarização»: das teses às dúvidas. Análise Social, v. 24, n. 101/102, p. 703-717, 1988. Disponível em $<$ http://analisesocial.ics.ul.pt/documentos/1223031386S1wGH8bg2Bw91DJ6.pdf>.

Acesso em: 25 mar. 2009.

FERREIRA, Aida. A terciarização no feminino. Serviço Social no Feminino - Jornadas Internacionais. Centro Português de Investigação em História e Trabalho Social CPIHTS, n. 51/58, jun. 1995. Disponível em <http://www.cpihts.com/PDF/Aida\%20 Ferreira.pdf>. Acesso em: 25 mar. 2009.

FERREIRA FILHO, Manoel Gonçalves. Direitos humanos fundamentais. São Paulo: Saraiva, 2002.

FONSECA, Maria Leila Rezende do Vale; ALENCAR, Edgard; BARBOSA, J. Humberto. Percepçao da força de trabalho no processo de mudança tecnológica e organizacional: um estudo de caso. OGT 01-04. Disponível em: <http://www.ichs.ufop.br/conifes/anais/OGT/ogt0104.htm>. Acesso em: 17 nov. 2010.

FUDGE, Judy, The new discourse of labor rights: from social to fundamental rights. Comparative Labor Law \& Policy Journal, v. 29, n. 1, 2007.

FUTATA, Marli Delmônico de Araújo. Breve análise sobre o toyotismo: modelo japonês de produção. Revista Espaço Acadêmico, n. 47, abr. 2005. Disponível em: <http://www.espacoacademico.com.br/047/47cfutata.htm>. Acesso em: 18 jul. 2011.

GAlVÃO, Andréia; BOITO JR., Armando; COLlETI, Claudinei; TRÓPIA, Patrícia. Lutas sociais no Brasil em 2001. p. 62. Observatorio Social de América Latina (OSAL), Buenos Aires, ene. 2002. Disponível em: <http://168.96.200.17/ar/libros/osal/osal6/sur.pdf>. Acesso em: 06 mar. 2011.

GARCIA, Gustavo Filipe Barbosa. Curso de direito do trabalho. São Paulo: Método, 2007. 
GAUDREY, Jean. Un demi-siècle de montée des services: la révolution permanente. $L e$ Mouvement Social, n. 211, p. 21-36, 2005. Disponível em: $<<$ http://www.cairn.info/article.php?ID_REVUE=LMS\&ID_NUMPUBLIE=LMS_211\& ID_ARTICLE=LMS_211_0021>. Acesso em: 03 abr. 2009.

GENNARI, Adilson Marques. Globalização, neoliberalismo e abertura econômica no Brasil nos anos. Pesquisa \& Debate, São Paulo, v. 13, n. 2, p. 30-45, 2001. Disponível em:

$<$ http://www.pucsp.br/pos/ecopol/downloads/edicoes/\%2821\%29adilson_marcos.pdf>. Acesso em: 03 abr. 2009.

GIANOTTI, Vitto. O que é estrutura sindical? 2. ed. São Paulo: Brasileirense, 1987.

GIDDENS, Anthony. As consequências da modernidade. São Paulo: Ed. UNESP, 1991. Books Google. Disponível em: <http://books.google.com.br>. Acesso em: 02 maio 2011.

GLOBALIZAÇÃO gera mais trabalho informal. Rádio das Nações Unidas, 29 nov. 2007. Disponível em: <http://www.unmultimedia.org/radio/portuguese/detail/153710.html>. Acesso em: 24 out. 2010.

GUERRA FILHO, Willis Santiago. Processo constitucional e direitos fundamentais. São Paulo: RCS Ed., 2005.

HUECK, A. NIPPERDEY, H.C. Compendio de derecho del trabajo. Trad. Espanhola de Rodriguez Piñero e De La Villa. Madrid: Ed. Revista de Derecho Privado, 1963.

INSTITUTO NACIONAL DE ESTATÍSTICA - PORTUGAL, disponível em $<\mathrm{http}: / /$ metaweb.ine.pt/sim/conceitos/Detalhe.aspx?cnc_cod=4684\&cnc_ini=22-032004\%200:00:00>. Acesso em: 02 abr. 2009.

INSTITUTO NACIONAL DE ESTATÍSTICA - PORTUGAL. Indicadores sociais edição de 2005, dez. 2006. Disponível em: <http://www.ine.pt>. Acesso em: 02 abr. 2009.

LEITE, Roberto Basilone. Desregulamentação, flexibilização e reconstrução do ordenamento trabalhista: o trabalhador entre o neoliberalismo e o garantismo. Revista LTr, São Paulo, ano 66, n. 12, p. 1413-1425, dez. 2002.

LIMA, Gerson. Uma interpretação da curva de oferta de Marshall e a arquitetura de uma moderna Teoria da Oferta e Demanda. Revista Econômica, v. 2, n. 4, p. 61-84, dez. 2000. Disponível em: <http://www.uff.br/revistaeconomica/v2n2/4-gersonlima.pdf>. Acesso em: 23 set. 2011. 
LIMA, Otávio Augusto Custódio de. Negociação coletiva: um caminho para a flexibilização. Projeto NEG. núcleo de Estudos sobre a Globalização. Disponível em: <http://globalization.sites.uol.com.br/negociao.htm>. Acesso em: 21 nov. 2010.

MACEDO, Roberto. Seu diploma, sua prancha. São Paulo: Saraiva, 1998.

MAGALHÃES, Daniel de Castro. Contratos coletivos de trabalho no sistema jurídico italiano: derrogabilidade/inderrogabilidade e flexibilização. Revista do Tribunal Superior do Trabalho, Brasília, v. 72, n. 2, p. 98-111, maio/ago. 2006.

MARRAS, Jean Pierre. Relações trabalhistas no Brasil: administração e estratégia. São Paulo: Futura, 2001.

MARTINEZ, Pedro Romano. Direito do trabalho. 3. ed. Coimbra: Almedina, 2006.

MARTINS, Mônica de Souza N. Entre a cruz e o capital: as corporações de ofício no Rio de janeiro após a chegada da família Real (1808-1824). Rio de Janeiro: Garamond Universitária, [2008]. Disponível em: $<$ http://www0.rio.rj.gov.br/arquivo/pdf/obras_premiadas_pdf/entre_cruz_capitall.pdf > Acesso em: 14 nov. 2010.

MARTINS, Sergio Pinto. Flexibilização das condições de trabalho. São Paulo: Atlas, 2009.

MARX, Karl. O capital: crítica da economia política. Rio de Janeiro: Civilização Brasileira, 2008. Livro 1, v. 2.

MATTOSO, Jorge. O Brasil desempregado: como foram destruídos mais de 3 milhões de empregos nos anos 90. São Paulo: Abramo, 1999.

MELO, Hildete Pereira de et al. O setor serviços no Brasil: uma visão global - 1985/95. Brasília: IPEA, 1998. (Texto para Discussão n. 549). Disponível em: <http://www.ipea.gov.br/pub/td/td0549.pdf>. Acesso em: 26 jun. 2010.

MONIZ, António Brandão. Estratégias de construção da Sociedade da Informação. Munich Personal RePEc Archive. Disponível em <http://mpra.ub.unimuenchen.de/6633/1/cap_2_EUPT_repec.pdf>. Acesso em: 21 mar. 2009.

MORAES FILHO, Evaristo de. A justa causa na rescisão do contrato de trabalho. 3. ed. São Paulo: LTr, 1996. 
MORAES, Alexandre de. Direitos humanos fundamentais. São Paulo: Atlas, 2005.

NASCIMENTO, Amauri Mascaro. Compêndio de direito sindical. 2. ed. São Paulo: LTr, 2000.

. Compêndio de direito sindical. 5. ed. São Paulo: LTr, 2008.

. Curso de direito do trabalho. 16. ed. São Paulo: Saraiva, 1999.

. Curso de direito do trabalho. São Paulo: Saraiva, 2003.

. Direito sindical. São Paulo: Saraiva, 1989.

. Direito do trabalho na Constituição de 1988. 2. ed. São Paulo: Saraiva, 1991.

. Perspectivas do direito sindical. Revista LTr, São Paulo, v. 63, n. 12, dez. 1999.

(Coord.). A transição do direito do trabalho no Brasil: estudos em homenagem a Eduardo Gabriel Saad. São Paulo: LTr, 1999.

NEOLIBERALISMO. FAU-USP, Disponível em: <http://www.usp.br/fau/docentes/depprojeto/c_deak/CD/4verb/neolib/index.html>. Acesso em: 05 out. 2009.

NIEMEYER, W. Movimento sindicalista no Brasil. Rio de Janeiro: [s.n.], 1933.

NOVA Enciclopédia Ilustrada Folha. São Paulo: Publifolha, 1996. v. 2.

OIT adopta Declaração sobre a justiça social para uma globalização justa. OIT Lisboa, ano $6, \quad$ n. $15, \quad$ set. $2008 . \quad$ Disponíivel em: $<$ http://www.ilo.org/public/portugue/region/eurpro/lisbon/pdf/newsl_15.pdf>. Acesso em: 30 set. 2009.

ORGANIZAÇÃO INTERNACIONAL DO TRABALHO. Declaração da OIT Sobre Justiça Social para uma Globalização Justa. Adoptada pela Conferência Internacional do Trabalho na $97^{\mathrm{a}}$ Sessão, Genebra, 10 de Junho de 2008. Disponíovel em: $<$ http://www.ilo.org/public/portugue/region/eurpro/lisbon/pdf/resolucao_justicasocial.pdf>. Acesso em: 28 set. 2009. 
PACTO Internacional dos Direitos Econômicos, Sociais e Culturais. Adotada pela Resolução n.2.200-A (XXI) da Assembléia Geral das Nações Unidas, em 16 de dezembro de 1966 e ratificada pelo Brasil em 24 de janeiro de 1992. Disponível em: $<$ http://www.oas.org/dil/port/1966\%20Pacto\%20Internacional\%20sobre\%20os\%20Direit os\%20Econ\%C3\%B3micos, \%20Sociais\%20e\%20Culturais.pdf>. Acesso em: 28 set. 2009.

PASTORE, José. A crise do sindicalismo. José Pastore. Disponível em: <http://www.josepastore.com.br/artigos/rt/rt_241.htm>. Acesso em: 19 nov. 2011.

A filosofia da reforma sindical. José Pastore. Disponível em: <http://www.josepastore.com.br/artigos/rt/rt_241.htm>. Acesso em: 19 nov. 2011.

PIMENTEL, Jaqueline. O Censo 2010 que aponta distribuição desigual de renda e o Cadastro de Empregados que registra queda do crescimento de postos de trabalho formais reforçam a necessidade de intervenção sobre os DSS. Disponível em: $<$ http://cmdss2011.org/site/2011/12/o-censo-2010-que-aponta-distribuicao-desigual-derenda-e-o-cadastro-de-empregados-que-registra-queda-do-crescimento-de-postos-detrabalho-formais-reforcam-a-necessidade-de-intervencao-sobre-os-dss/>. Acesso em: 04 abr. 2010.

QUADROS, Valdir. Classes sociais e desemprego no Brasil dos anos 1990. Economia e Sociedade, Campinas, v. 12, n. 1, p. 109-135, jan./jun. 2003.

RAMALHO, Maria do Rosario Palma. Ainda a crise do direito laboral: a erosão da relação de trabalho "típica" e o futuro do Direito do Trabalho. In: MOREIRA, Antonio (Coord.) III Congresso Nacional de Direito do Trabalho - Memórias. LISBOA: Almedina, 2000.

2000.

Da autonomia dogmática do direito do trabalho. 1. ed. Coimbra: Almedina, Insegurança ou diminuição do emprego? A rigidez do sistema jurídico português em matéria de cessação do contrato de trabalho e de trabalho atípico. Revista LTr, São Paulo, v. 64, n. 8, ago. 2000.

RIBEIRO NETO, Luiz Gonzaga. Os impactos da tecnologia de informação nas organizações: uma visão política $R$. Un. Alfenas, Alfenas, n. 5, p. 95-101, 1999. Disponível em: <http://www.unifenas.br/pesquisa/download/ArtigosRev1_99/pag95101.pdf>. Acesso em: 04 abr. 2010. 
ROBERT Owen. Disponível em: <http://www.algosobre.com.br/biografias/robertowen.html>. Acesso em: 15 maio 2011.

RODA Viva - Octavio Ianni. Roda viva - octavio ianni.doc - UFSC. Entrevista para Paulo Markun. Biblioteca Práxis - Rede Social. Disponível em: <bib.praxis.ufsc.br>.

RODRIGUES, Iram Jácome; RAMALHO, José Ricardo. Dilemas do sindicalismo na Inglaterra e no Brasil: uma abordagem comparativa. Texto apresentado ao XXII ENCONTRO ANUAL DA ASSOCIAÇÃO DE PÓS-GRADUAÇÃO EM CIÊNCIAS SOCIAIS (ANPOCS). Caxambú, MG, 27 a 30 de outubro de 1998. Disponível em: <bibliotecavirtual.clacso.org.ar/ar/libros/anpocs/jacome.rtf>. Acesso em: 14 out. 2011.

RODRIGUES, Leôncio Martins. Destino do sindicalismo. São Paulo: EDUSP; FAPESP, 2002.

ROMITA, Arion Sayão. Os direitos sociais na Constituição e outros estudos. São Paulo: LTr, 1991. O princípio da proteção em xeque. São Paulo: LTr, 2003.

A terciarização e o direito do trabalho. Revista LTr, São Paulo, v.56, n. 3, mar. 1992.

RUBERTI, Kellen Cristina; GELINSKI, Carmen Rosário Ortiz Gutierrez; GUIMARÃES, Valeska Nahas. Relações de trabalho no setor de serviços no contexto da reestruturação produtiva. Disponível em: $<$ http://www.fee.tche.br/sitefee/download/jornadas/2/e8-03.pdf>.

RUSSOMANO, Mozart Victor. Princípios gerais de direito sindical. 2. ed. Rio de Janeiro, Forense, 1998.

SARLET, Ingo Wolfgang. Dignidade da pessoa humana e direitos fundamentais. 4. ed. Porto Alegre: Livr. do Advogado, 2006.

SCALZARETTO, Reinaldo. Geografia geral: nova geopolítica. 8. ed. São Paulo: Scipione, 2001.

SETOR de serviços puxou criação de empregos em outubro. Saldo líquido do setor foi de 77 mil vagas no mês. Veja, São Paulo, 18 nov. 2011.

SILVA, Alexandre Messa et al. Economia de serviços: uma revisão de literatura. Brasília: IPEA, 2006. (Texto para Discussão n. 1173). Disponível em: <http://www.ipea.gov.br/pub/td/2006/td_1173.pdf>. 
SILVA, Antônio Álvares da. Direito coletivo do trabalho. Rio de Janeiro: Forense, 1979.

SILVA, José Afonso da. Curso de direito constitucional positivo. 23. ed. São Paulo: Malheiros Ed., 2004.

SINDICATOS DOS BANCÁRIOS E FINANCIÁRIOS DE SÃO PAULO. Convenção 158 da OIT: que bicho é esse? Disponível em: $<$ http://www.spbancarios.com.br/noticia.asp?c=5792>.

SOUTO MAIOR, Jorge Luiz. Proteção contra a dispensa arbitrária e aplicação da Convenção 158 da OIT. Revista de Direito do Trabalho, São Paulo, ano 30, n. 116, p. 110-125, out./dez. 2004.

SOUZA, Zoraide Amaral de. A Organização Internacional do Trabalho - OIT. Revista da Faculdade de Direito de Campos, ano 7, n. 9, p. 426-465, dez. 2006.

STÜRMER, Gilberto. A liberdade sindical na Constituição da República Federativa do Brasil e sua relação com a Convenção 87 da Organização Internacional do Trabalho. Porto Alegre: Livr. do Advogado Ed., 2007.

SULZBACH, Mayra Taiza; DENARDIN, Valdir Frigo. O impacto da regulamentação do mercado de trabalho frente a fragilidade orçamentária e do emprego nos municípios do litoral do Paraná. Universidade Federal do Rio Grande do Norte, CCHLA. Disponível em: <http://www.cchla.ufrn.br>. Acesso em: 15 abr. 2010.

SÜSSEKIND, Arnaldo. Convenções da OIT. São Paulo: LTr, 2000.

Direito internacional do trabalho. São Paulo: LTr, 1987.

; MARANHÃO, Délio; VIANNA, Segadas; TEIXEIRA FILHO, João de Lima. Instituições de direito do trabalho. 16. ed. atual. São Paulo: LTr, 1996.

VIANNA, Segadas. Antecedentes históricos. In: MARANHÃO, Délio; SÜSSEKIND, Arnaldo; TEIXEIRA, Lima; VIANNA, Segadas. Instituições de direito do trabalho. 16. ed. São Paulo: LTr, 1996, v. 1, p. 32-33.

. Direito coletivo do trabalho. São Paulo: LTr, 1972.

VICECONTI, Paulo Eduardo V.; NEVES, Silvério das. Introdução à economia. 2. ed. São Paulo: Frase Ed, 1997. 
WTO. Disponível em: <http://www.wto.org/english/docs_e/legal_e/06-gatt_e.htm>.

ZYLBERSTAJN, Hélio. Sindicalismo, Leis de Marshall e globalização. Informações Fipe, n. 232, p. 17-19, jan. 2000. 